\title{
Criteria and Indicators for Sustainable Plantation Forestry in India
}

S. Sankar

P.C. Anil

M. Amruth
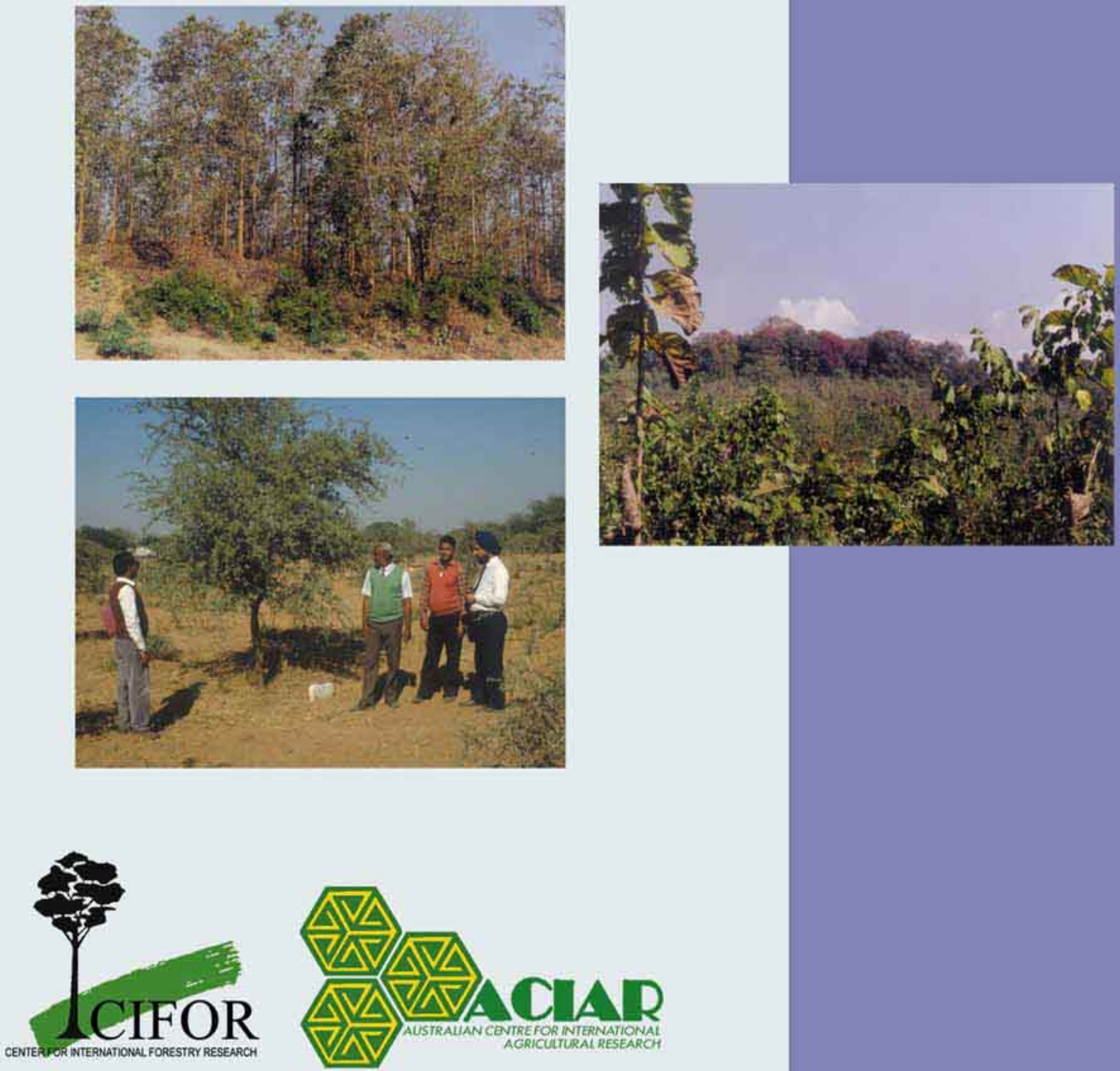


\title{
Criteria and Indicators for Sustainable Plantation Forestry in India
}

\author{
S. Sankar, P.C. Anil and M. Amruth
}

In collaboration with

Ram Prasad, S. Raghavan, Abey George, S.P. Singh, Jyothi Krishnan,

D. Duggai, M. Mishra, B. Sreekumar and S.C. Prasad
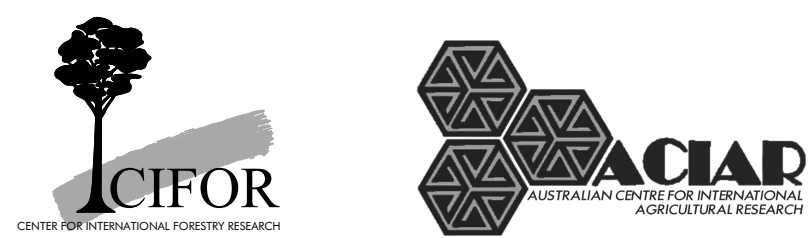
(C) 2000 by Center for International Forestry Research

All rights reserved. Published in December 2000

Printed by SMT Grafika Desa Putera, Indonesia

\section{ISBN 979-8764-54-4}

Cover photos:

Christian Cossalter

Sankar, C., Anil, P.C. and Amruth, M. 2000.

Criteria and Indicators for Sustainable Plantation Forestry in India.

Center for International Forestry Research, Bogor, Indonesia. 72 p.

\section{Published by}

Center for International Forestry Research

Bogor, Indonesia

P.O. Box 6596 JKPWB, Jakarta 10065, Indonesia

Tel.: +62 (251) 622622; Fax: +62 (251) 622100

E-mail: cifor@cgiar.org

Web site: http://www.cifor.cgiar.org

with support from

Australian Centre for International Agricultural Research (ACIAR)

GPO Box 1571

Canberra ACT 2601

Australia

Website: http://www.aciar.gov.au 


\section{Table of Contents}

Acknowledgements $\quad$ vi

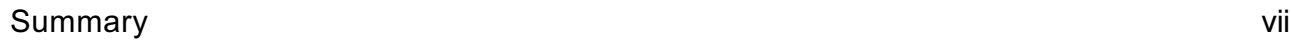

$\begin{array}{lr}\text { 1. Introduction } & 1\end{array}$

2. Methods 3

$\begin{array}{lr}\text { 3. Results and Discussion } & 7\end{array}$

$\begin{array}{lr}\text { 4. Conclusions } & 33\end{array}$

$\begin{array}{ll}\text { 5. References } & 35\end{array}$

Annexes:

$\begin{array}{lll}\text { Annex 1. Form 1 } & 37\end{array}$

$\begin{array}{lll}\text { Annex 2. } & \text { Form } 2 & 38\end{array}$

Annex 3.1 Criteria and indicators of sustainable management for $\quad 41$ teak plantations in Kerala selected after field testing by Team 1

Annex 3.2 Criteria and indicators of sustainable management for eucalypt plantations in Kerala selected after field testing by Team 2

Annex 3.3 Criteria and indicators of sustainable management for teak plantations of Madhya Pradesh selected after field testing by Team 3

Annex 4. Example of a field diary, Dr Manish Misra-Bhopal Team 


\section{List of Tables}

Table 1. Team 1 - Teak, Kerala 5

$\begin{array}{lll}\text { Table 2. Team } 2 \text { - Eucalypt, Kerala } & 6\end{array}$

$\begin{array}{lll}\text { Table } 3 . & \text { Team } 3 \text { - Teak, Madhya Pradesh }\end{array}$

$\begin{array}{lll}\text { Table 4. Number of C\&I selected for field testing } & 7\end{array}$

Table 5. Number of C\&I accepted as final after field testing by Teams 8

Table 6. Changes in the total number of C\&I between pre-field and post-field evaluation (Accepted C\&I) 8

Table 7. Average scores for 215 Criteria and Indicators against 9 key attributes

Table 8.1 Analysis of Commonalities

Policy - Criterion 1.1 (Bhopal)

Table 8.2 Analysis of Commonalities

Policy - Criterion 1.1 (Kerala)

Table 8.3 Analysis of Commonalities

Policy - Criterion 1.2 (Bhopal)

Table 8.4 Analysis of Commonalities

Policy - Criterion 1.3 (Bhopal)

Table 8.5 Analysis of Commonalities

Policy - Criterion 1.4 (Bhopal)

Table 8.6 Analysis of Commonalities

Policy - Criterion 1.5 (Bhopal)

Table 8.7 Analysis of Commonalities

Policy - Criterion 1.6 (Bhopal)

Table 9.1 Analysis of Commonalities

Ecology - Criterion 2.1 (Kerala)/2.4 (Bhopal)

Table 9.2 Analysis of Commonalities

Ecology - Criterion 2.2 (Kerala and Bhopal)

Table 9.3 Analysis of Commonalities

Ecology - Criterion 2.3 (Kerala and Bhopal)

Table 9.4 Analysis of Commonalities

Ecology - Criterion 2.1 (Bhopal) 
Table 9.5 Analysis of Commonalities

Ecology - Criterion 2.5 (Bhopal)

Table 10.1 Analysis of Commonalities

Social - Criterion 3.1 (Kerala and Bhopal)

Table 10.2 Analysis of Commonalities

Social - Criterion 3.2 (Kerala and Bhopal)

Table 10.3 Analysis of Commonalities

Social - Criterion 3.3 (Kerala and Bhopal)

Table 10.4 Analysis of Commonalities

Social - Criterion 3.4 (Kerala and Bhopal)

Table 10.5 Analysis of Commonalities

Social - Criterion 3.5 (Kerala and Bhopal)

Table 10.6 Analysis of Commonalities

Social - Criterion 4.1 (Kerala)/3.6 (Bhopal)

Table 11.1 Analysis of Commonalities

Management - Criterion 5.1 (Kerala)/4.1 (Bhopal)

Table 11.2 Analysis of Commonalities

Management - Criterion 5.2 (Kerala)/4.2 (Bhopal)

Table 11.3 Analysis of Commonalities

Management - Criterion 5.3 (Kerala)/4.3 (Bhopal)

Table 11.4 Analysis of Commonalities

Management - Criterion 5.4 (Kerala)/4.4 (Bhopal)

Table 12. Sources of PCIV in plantations in Kerala 25

Table 13. Sources of PCIV in plantations in Madhya Pradesh 26

Table 14. Level of commonality of C\&I for the compiled final set 26

Table 15. Final set of criteria and indicators of sustainable management for tropical plantation forests in India 


\section{Acknowledgements}

This work has been strongly supported by Senior Officers of the Kerala Forest Department, Madhya Pradesh Forest Department and Madhya Pradesh Forest Development Corporation. Scientists of KFRI and IIFM contributed significantly by testing and developing the C\&I. Dr K.S.S. Nair (Former Director, KFRI) and Dr J.K. Sharma (Director, KFRI) accorded unstinting cooperation. Dr Ravi Prabhu, Dr Carol Colfer and C\&I team members of CIFOR provided guidance through publications, reports and CIMAT. The authors are indebted to Dr Christian Cossalter (CIFOR, Indonesia) and Dr Peter Hopmans (Centre for Forest Tree Technology, Australia) for academic and personal support. Authors are also thankful to Ms Ajitha S, for meticulously word processing the manuscript. 


\section{Summary}

Forest plantations are an important resource of wood, fuel and a variety of other forest products in India. Development of a framework of criteria and indicators (C\&I) for the sustainable management of plantations has been given high priority in the National Forest Policy, revised in 1988. Furthermore, a national initiative known as the Bhopal-India Process was undertaken recently to propose C\&I for sustainable forest management in India.

In recent years CIFOR has developed a system for testing C\&I for assessing the sustainability of management of natural forests at the level of a forest management unit (FMU). This system was used to develop C\&I for teak and eucalypt plantations in two states in India. Development and evaluation of C\&I was conducted by the Kerala Forest Research Institute (KFRI), Peechi, Kerala, in collaboration with the Indian Institute of Forest Management, Bhopal, in Madhya Pradesh. The project provided an opportunity for forestry scientists, forest managers, local communities, and NGOs in Kerala and Madhya Pradesh to participate in the testing and evaluation of C\&I of sustainable management of plantations based on the Iterative Filtering and Generation Method (IFGM) developed for natural forests by CIFOR.

Field testing in Kerala was conducted in an age series of teak plantations at Nilambur and in young eucalypt plantations of the Punalur forest district. Both FMUs were managed by the Department of Forestry in Kerala. In Madhya Pradesh field testing was conducted in teak plantations of the Raipur district managed by the Madhya Pradesh Forest Development Corporation (MPFDC).

The selection of candidate sets of C\&I during stage 1 of the IFGM process from the vast array of published information was found to be time consuming. To rationalise this process teams found it necessary to first group all C\&I under four principles: viz. policy and planning, ecology, socioeconomic and management. These were then further divided into subgroups before starting the selection process (Filter 1) for the candidate sets for field testing.

Field testing of C\&I based on stage 2 of the IFGM process evolved and teams became more proficient during the two tests conducted in Kerala and the third test later on in Madhya Pradesh. The three teams defined sets of C\&I, as well as verifiers for some indicators, specific to each test site. Comparison of these three sets showed that a high proportion of policy indicators proposed for teak plantations in Madhya Pradesh were unique (Table 14) due to differences in forest policies and organisations responsible for managing plantations in the two states. Likewise, a number of ecology indicators addressed specific local issues. A large number of socio-economic indicators were common for all sites reflecting similarity of social issues. Management issues were also similar, consistent with the historical development of plantation management in the two states.

Stakeholder participation during the field tests and final workshops, including local communities and NGOs played an essential role in shaping C\&I related to social and economic concerns. This raised a number of important issues including: 
- impact of plantation development on water supplies to villages and settlements;

- loss of biodiversity and the long-term impact on NWFP collected by local communities to supplement income;

- sharing of benefits from plantation development to improve opportunities for schooling, training and employment; and

- environmental impacts, such as soil erosion and contamination.

The site-specific C\&I developed by the three teams were examined for commonalities and this formed the basis for a minimum set of C\&I applicable to the three sites included in this project and considered to be more widely relevant to plantation forestry across India.This evaluation also identified a number of unique C\&I addressing policy, ecological and socio-economic issues of local importance. The results from this project demonstrated the importance of testing and evaluating C\&I at the FMU level to ensure that local issues pertaining to the sustainable management of forest plantations are addressed. 


\section{Introduction}

There are over 100 countries in the world involved in developing national-level criteria and indicators for assessing trends in the state of their forests (Wijewardena et al. 1977). Despite similarities in the fundamental elements of C\&I, experiences differ from country to country and within regions. CIFOR has led a research project on testing criteria and indicators for sustainable management of natural forests involving several governmental and non-governmental organisations (Prabhu et al. 1996, 1998). The present project used this experience to develop and evaluate C\&I for community managed forests and tree plantations in India.

Forest plantations in India now comprise some 19 million ha and represent a significant proportion of the total plantation resource of around 70 million ha in the Asia-Oceania region. (See
FAO, State of the World's Forests for data on international plantation resources.) Sustainable management of plantations is important for ensuring an adequate supply of wood and other forest products for future generations. Hence this project on testing $\mathrm{C} \& \mathrm{I}$ for forest plantations was taken up in India. Testing was conducted in two states: Kerala, where the first teak plantation in the world was established as early as 1841; and in Madhya Pradesh, which has the largest recorded area of natural forests and plantations in the country. The lead institution was the Kerala Forest Research Institute (KFRI), Peechi, Kerala, in collaboration with the Indian Institute of Forest Management, Bhopal, in Madhya Pradesh. Testing was carried out in Kerala on teak and eucalypt plantations and in Madhya Pradesh on teak plantations only. 


\section{Methods}

The CIFOR process for developing, testing and selecting C\&I for sustainable forest management is based on an Iterative Filtering and Generation Method (IFGM) comprising three stages of evaluation or filters (Prabhu et al. 1999).

- The first stage (Filter No. 1) identifies an appropriate set of C\&I from various sources, based mainly on professional judgement by the expert team(s).

- The second stage (Filter No. 2) evaluates the candidate set on-site based on discussions and interviews with stakeholders, field surveys and documented information. Regular team discussions are held during this stage to review and revise proposed C\&I and to address overlap and discrepancies.

- The third stage (Filter No. 3) is a post-field workshop to review and revise the proposed C\&I with input from the team, as well as invited participants with expertise in the various disciplines. Following this workshop a final report is prepared by the team on C\&I selected for each site, including comments on the IFGM process.

The CIFOR IFGM process was adopted for the development of C\&I for plantations in Kerala and Madhya Pradesh. Three interdisciplinary expert teams were constituted in Kerala (Teams 1 and 2) and Madhya Pradesh (Team 3) to select and evaluate C\&I for teak and eucalypt plantations in Kerala, and for teak plantations in Madhya Pradesh. The composition of the teams is provided in Tables 1-3.
In accordance with CIFOR guidelines, the teams were familiarised with the IFGM process for testing C\&I and thereafter candidate sets were selected from published C\&I developed by the following organisations:

1. International Tropical Timber Organization (1992)

2. Amazon Cooperation Treaty A.C. (1995)

3. The Montreal Process (1995)

4. African Timber Organization (1998)

5. Forest Stewardship Council A.C. (1996)

6. Scientific Certification Systems (1998)

7. SmartWood Programme (1993)

8. The Soil Association Marketing Company Ltd. (1994)

9. Bhopal-India Process (1999)

10. National Forest Policy (1988)

The candidate sets for field testing were selected or new ones were created using CIFOR Filter 1 (See Annex 1, Form 1). This process of familiarisation with the IFGM conceptual framework of testing and developing C\&I and the selection of candidate sets for field testing took 10 days. During the filtering process the teams referred regularly to two vital documents available for the Indian tests: The National Forest Policy of 1988 and the proposed national C\&I being developed through the Bhopal-India Process (BIP 1999).

As part of the second stage of the IFGM process (see Annex 2, Filter 2), field tests were carried out in respective Forest Management Units, closely involving local staff, stakeholders and other 
users. Periodic visits, questionnaire surveys, interviews, Participatory Rural Appraisal, etc. were the common methods used to collect the information needed for this stage. Each C\&I was evaluated in the field by team members and their opinions and scoring were analysed to define practical sets of C\&I.

The C\&I sets developed for each field site were reviewed again by the teams in a final postfieldwork workshop (Filter 3) to formulate the final C\&I specific to each site.

\subsection{Description of Test Sites}

\subsubsection{Teak plantations in Kerala}

Natural forests in the state of Kerala range from temperate hill forests to dry scrub jungles and are recognised for their rich biodiversity of flora and fauna. Traditionally, production of wood has been the major objective of forest management. More recently the attention of forest management has turned to conservation, ecological balance, ecorestoration, recreation, biodiversity conservation and finally to multiple use management with people's participation.

The Kerala Forest Department is the single largest teak planter in Kerala and is responsible for the management of about 65,000 ha of teak plantations. The first recorded teak plantation in the world was established at Nilambur, Kerala, in 1841. Until the 1980s, teak was raised after clear felling natural forests. After a ban on clear felling was introduced in 1982, new plantations are established only in areas already under teak.

At Nilambur the site quality distribution is skewed towards $\mathrm{IV}^{\text {th }}$ and $\mathrm{V}^{\text {th }}$ classes and plantations of age $<30$ years predominate. Growth is generally slow, as indicated by the average Mean Annual Increment (MAI) of $2.4 \mathrm{~m}^{3} / \mathrm{ha} / \mathrm{yr}$ compared with an estimated potential MAI of 5.0 $\mathrm{m}^{3} / \mathrm{ha} / \mathrm{yr}$. Management practices such as soil erosion control, fertiliser input, soil cultivation and genetic improvement all contribute to the ecological, social and economic sustainability of teak plantations.
An age series of plantations (1-60 years) at Nilambur was selected for the field testing of C\&I. The FMU (250 ha) comprised a forested catchment with varying slopes and aspects and a permanent stream.

The population at the Nilambur test site of around 700 people, including four tribal settlements, depends on plantation labour, nonwood forest products (NWFP), casual labour and cottage industries. The main opportunities for unskilled labour in plantations include fire watching, nursery management, planting, weeding, fertilising and thinning, as well as more skilled jobs such as final felling, grading, loading and transportation.

\subsubsection{Eucalypt plantations in Kerala}

Eucalypts were introduced in Kerala in the late 1950s for pulpwood. There are about 90,000 ha of eucalypt plantations managed by the Kerala Forest Department and Kerala Forest Development Corporation. Nearly $56 \%$ of the area is above 20 years of age. The dominant species are Eucalyptus tereticornis and E. grandis. The yield of eucalypt ranges from 7 to $10 \mathrm{~m}^{3} / \mathrm{ha} / \mathrm{yr}$, which is well below international yields. Correct matching of sites and species are considered to be the important criteria for increasing the productivity of this species.

The E. tereticornis plantations of the Punalur Forest Division, comprising an FMU of around 200 ha, were selected for the development and testing of C\&I by Team 2. The test was conducted in an age series of 1 to 6 years of first and second rotation coppice regrowth and also in recently established clonal plantations (clones from Bhadrachalam Paper Boards, Andhra Pradesh, India).

The FMU is surrounded by rubber plantations and three settlements of local people, including farmers with paddy fields and unskilled labourers. There is opportunity for seasonal employment as fire watchers, nursery men and for planting and tending operations to supplement income from farming. The felling, processing and transportation of harvested materials is mostly done by contract labour imported from other locations. 


\subsubsection{Teak plantations in Madhya Pradesh} Madhya Pradesh accounts for about $25 \%$ of the total forest area of India. The state harbours a rich flora of some 1860 species of flowering plants. The state is also rich in wildlife including tigers, swamp deer and wild buffalo, and is the torch bearer of wildlife conservation in India with more than $15 \%$ of the country's total tiger population.

Since the 1950 s approximately 1.7 million ha of natural forests have been converted to agricultural land use. Teak plantations of varying site quality comprise about 1 million ha making Madhya Pradesh one of the most important teakgrowing states in India. The Madhya Pradesh Forest Development Corporation manages about 33,120 ha of teak plantations. The field testing of C\&I was carried out in 1184 ha of plantations in the North Forest Division of Raipur, part of the Barnawapara project. The general topography of the region is flat to undulating with elevation ranging from $225-550 \mathrm{~m}$. The project area is the catchment of the Mahanadi River. The climate is hot and humid with an annual summerdominated rainfall of $1200 \mathrm{~mm}$. The growth of teak is generally poor with an average MAI of $2.5 \mathrm{~m}^{3} / \mathrm{ha} / \mathrm{yr}$ and management practices are directed towards enhancement of productivity.

The FMU includes 12 settlements of mainly farming communities managing about 1400 ha of agricultural land of low productivity. Low crop production together with scarcity of water has resulted in famine and starvation during off-seasons. Villagers rely heavily on income from plantation activities such as planting, thinning, fire protection, felling and maintenance of roads for their survival. In addition, income is derived from the collection of Tendu leaves (Diospyros malanoxylon), an important NWFP that provides a supplementary income for many households in this region.

\subsection{Composition of test teams}

The expertise and professional experience of team members together with their familiarity and proficiency with C\&I of sustainable forest management has been summarised for each team in Tables 1-3 below.

Table 1. Team 1 - Teak, Kerala

\begin{tabular}{|c|c|c|c|c|c|}
\hline $\begin{array}{l}\text { Sl. } \\
\text { No. }\end{array}$ & Expertise & $\begin{array}{c}\text { Years of } \\
\text { experience }\end{array}$ & $\begin{array}{l}\text { Knowledge } \\
\text { of C\&I }\end{array}$ & Country & Site/Knowledge \\
\hline 1. & Forester & 30 & Some & India & 30 years in Kerala \\
\hline 2. & Plantation management & 8 & Good & India & Experience in Kerala and Pondicherry \\
\hline 3. & Biodiversity & 5 & Some & India & Expert in Kerala forest biodiversity \\
\hline 4. & Anthropology & 5 & Good & India & $\begin{array}{l}\text { Experience in social anthropology of } \\
\text { Kerala }\end{array}$ \\
\hline 5. & Gender specialist & 10 & Some & India & Problems of women in Kerala \\
\hline 6. & Social scientist & 20 & Good & India & $\begin{array}{l}\text { Experience in forest-people } \\
\text { interactions }\end{array}$ \\
\hline 7. & Soil, Ecology & 25 & Good & India & Forest soils of Kerala and productivity \\
\hline
\end{tabular}


Table 2. Team 2 - Eucalypt, Kerala

\begin{tabular}{llccll}
\hline $\begin{array}{c}\text { SI. } \\
\text { No. }\end{array}$ & $\begin{array}{c}\text { Years of } \\
\text { experience }\end{array}$ & $\begin{array}{c}\text { Knowledge } \\
\text { of C\&I }\end{array}$ & Country & Site/Knowledge \\
\hline 1. & Forester & 15 & Some & India & Plantation forestry in Kerala \\
2. & Plantation management & 10 & Some & India & Eucalypt specialist \\
3. Gender specialist & 5 & Some & India & Women's issues in Kerala \\
4. Botany & 15 & Good & India & Experience in Western Ghat Kerala \\
5. Soil, Ecology & 20 & Good & India & Soil fertility, site management in Kerala \\
6. Social science & 15 & Some & India & Experience in Kerala \\
7. Forest economics & 15 & Good & India & \\
\hline
\end{tabular}

Table 3. Team 3 - Teak, Madhya Pradesh

\begin{tabular}{|c|c|c|c|c|c|}
\hline $\begin{array}{l}\text { Sl. } \\
\text { No. }\end{array}$ & Expertise & $\begin{array}{c}\text { Years of } \\
\text { experience }\end{array}$ & $\begin{array}{l}\text { Knowledge } \\
\text { of C\&I }\end{array}$ & Country & Site/Knowledge \\
\hline 1. & Forester & 20 & Some & India & $\begin{array}{l}15 \text { years in Orissa \& } 2 \text { years in } \\
\text { Madhya Pradesh }\end{array}$ \\
\hline 2. & Plantation management & 8 & Good & India & Experience in Kerala \\
\hline 3. & Biodiversity & 10 & Some & India & Experience in Madhya Pradesh \\
\hline 4. & Social science & 15 & Some & India & Experience in Madhya Pradesh \\
\hline 5. & Social science & 15 & Some & India & Experience in Kerala \\
\hline 6. & Biodiversity & 10 & Some & India & Experience in Madhya Pradesh \\
\hline 7. & Soil, Ecology & 20 & Good & India & $\begin{array}{l}\text { Experience in Kerala and } \\
\text { Madhya Pradesh }\end{array}$ \\
\hline
\end{tabular}




\section{Results and Discussion}

\subsection{Evaluation of Criteria and Indicators through Form 1}

All teams were provided with the 'tool box' for testing C\&I developed by Prabhu et al. (1998). The base set consists of C\&I from the eight organisations as listed in the methods section. A summary of the candidate sets selected for field testing by each of the teams after the first evaluation (Filter 1) is provided in Table 4.

Because of their familiarity with ecology, socio-economic and management issues, the team members gave approximately equal weight to the different principles of sustainable management of plantation forests.

\subsection{Field evaluation of Criteria and Indicators}

The candidate sets of C\&I were taken to the field and evaluated based on stage 2 of the IFGM process using Form 2. The evaluations were carried out in teak and eucalypt plantations and a complete listing of Principles, Criteria, Indicators and some Verifiers (PCIV) selected for each site after field testing by the teams is provided in Annexes 3.1-3.3. A summary of C\&I accepted by each team after field testing is shown in Table 5.

After completion of stage 2 field testing, the two teams in Kerala proposed 5 principles (two for Social issues) while the third team in Madhya Pradesh proposed only 4. Furthermore, the total C\&I accepted by the teams were 18 criteria and 55 indicators by Team 1, 18 criteria and 56 indicators by Team 2, and 21 criteria and 47 indicators by Team 3 . After the field evaluation there was a reduction in policy C\&I tested and accepted by Teams 1 and 2, and an increase in C\&I for policy, ecology and social principles accepted by Team 3 (Table 6). The changes in the number of C\&I after field testing of the candidate set selected by the teams during stage 1 (Filter 1) are shown for each site in Table 6. There was an overall reduction in C\&I from 228 to 215 following stage 2 field testing.

Table 4. Number of C\&I selected for field testing

\begin{tabular}{clllcc}
\hline Teams & Policy & Ecology & Social & Management & Total \\
\hline T1 & $24(29 \%)$ & $19(22 \%)$ & $24(29 \%)$ & $17(20 \%)$ & $84(100 \%)$ \\
T2 & $24(29 \%)$ & $19(22 \%)$ & $24(29 \%)$ & $17(20 \%)$ & $84(100 \%)$ \\
T3 & $9(15 \%)$ & $14(23 \%)$ & $20(29 \%)$ & $17(28 \%)$ & $60(100 \%)$ \\
Total & 57 & 52 & 68 & 51 & \\
Ave. & 19 & 17.3 & 22.7 & 17 & \\
\hline
\end{tabular}


Table 5. Number of C\&l accepted as final after field testing by Teams

\begin{tabular}{lccc}
\hline & Team 1 & Team 2 & Team 3 \\
\hline Total C\&l selected for field testing & 84 & 84 & 60 \\
C\&l accepted after field testing: & & & 13 \\
Policy & 14 & 14 & 15 \\
Ecology & 18 & 19 & 23 \\
Social & 24 & 24 & 17 \\
Management & 17 & 17 & 68 \\
Total C\&I (Final) & 73 & 74 & \\
\hline
\end{tabular}

Table 6. Changes in the total number of C\&I between pre-field and post-field evaluation (Accepted C\&I)

\begin{tabular}{|c|c|c|c|c|c|c|c|c|}
\hline \multirow[t]{2}{*}{ Teams } & \multicolumn{2}{|c|}{ Policy } & \multicolumn{2}{|c|}{ Ecology } & \multicolumn{2}{|c|}{ Social } & \multicolumn{2}{|c|}{ Management } \\
\hline & Pre & Post & Pre & Post & Pre & Post & Pre & Post \\
\hline $\mathrm{T} 1$ & 24 & 14 & 19 & 18 & 24 & 24 & 17 & 17 \\
\hline T2 & 24 & 14 & 19 & 19 & 24 & 24 & 17 & 17 \\
\hline T3 & 9 & 13 & 14 & 15 & 20 & 23 & 17 & 17 \\
\hline
\end{tabular}

As part of the stage 2 evaluation, C\&I are given a ranking for each of nine attributes considered to be important as a measure of suitability and utility of a particular indicator (see Prabhu et al. 1999). A scale of 1 to 5 was used to rank C\&I, where 1 means unimportant/no utility and 5 means important/high utility. The ranking of C\&I field tested by the teams was summarised for all sites and average scores are given for each attribute (Table 7). Maximum scores were achieved for indicators addressing Management issues as the C\&I were generally considered to be easy to detect, record and interpret. High values for Social issues were achieved for 'closely related to assess goal' and 'C\&I are relevant'. Policy issues often received low values because of the difficulty in distinguishing between national and FMU levels and the vague nature of each indicator. The characteristics of C\&I for Ecology also received low scores as team members felt that reproducible results are difficult to achieve. The evaluation against these standard attributes showed some of the strengths and weaknesses of C\&I.
It also highlights the importance of accepting a degree of overlap between C\&I to ensure that specific aspects of sustainability are addressed thoroughly.

\subsection{Content analysis of C\&I proposed by teams}

One of the objectives of this project is to propose a minimum set of C\&I for the assessment of sustainability of plantations across India. Accordingly, the three sets of C\&I selected after field testing by the teams (as shown in Annexes 3.1-3.3) were compared on the basis of their content to obtain a core set applicable to all three sites. A comparison of the selected C\&I relating to various principles is provided in Tables 8, 9, 10 and 11. Comments and background information explaining commonalities and differences between C\&I for each of the sites are provided with each table. 
Table 7. Average scores ${ }^{\star}$ for 215 Criteria and Indicators against 9 key attributes

\begin{tabular}{lcccc}
\hline \multicolumn{1}{c}{ Attribute of C\&I } & Policy & Ecology & Social & Management \\
\hline Summary/integrative measure & 3.8 & 3.7 & 3.8 & 4.4 \\
Closely related to assess goal & 3.4 & 3.6 & 4.0 & 4.0 \\
Response range to stress & 3.3 & 3.5 & 3.8 & 3.9 \\
Diagnosticaly specific & 3.2 & 3.5 & 3.8 & 3.9 \\
Appealing to user & 3.5 & 3.4 & 3.9 & 4.4 \\
Easy to detect, record, interpret & 3.8 & 3.4 & 3.8 & 4.5 \\
Precisely defined & 3.5 & 3.5 & 3.9 & 4.3 \\
Produces replicable results & 3.7 & 3.3 & 4.0 & 4.4 \\
Relevant & 3.7 & 4.0 & 4.6 & 4.4 \\
Total & 31.8 & 32.0 & 35.6 & 38.1 \\
Average & 3.5 & 3.5 & 4.0 & 4.2 \\
\hline
\end{tabular}

* average of three teams

Table 8.1 Analysis of Commonalities

Policy - Criterion 1.1 (Bhopal)

\begin{tabular}{|c|c|c|}
\hline $\begin{array}{l}\text { Team } \\
\text { Test }\end{array}$ & Criterion (Id No./Description) & Indicators (Id No./Description) \\
\hline $\begin{array}{l}\text { Kerala } \\
\text { Team } 1\end{array}$ & & \\
\hline $\begin{array}{l}\text { Kerala } \\
\text { Team } 2\end{array}$ & & \\
\hline $\begin{array}{l}\text { Bhopal } \\
\text { Team } 3\end{array}$ & $\begin{array}{l}\text { 1.1 There exists policy and legal framework } \\
\text { for plantation land use }\end{array}$ & \\
\hline
\end{tabular}

Notes:

Plantation forestry in India has a long history originating in the 1840s. Through observation and experimentation, British foresters had developed silvicultural, administrative and legal frameworks for plantation forestry, establishment, management and development. These are reflected in detail in the forest working plans and crystallised in forest policies (Forest Policy of 1895). Since independence two more forest policies have been formulated (Forest Policy 1952 and 1988). Hence only one team (Team 3) insisted on retaining this criterion. Indicators are absent as these could not be well defined; possibly required for C\&l at the national level and not at FMU level. 
Table 8.2 Analysis of Commonalities

Policy - Criterion 1.1 (Kerala)

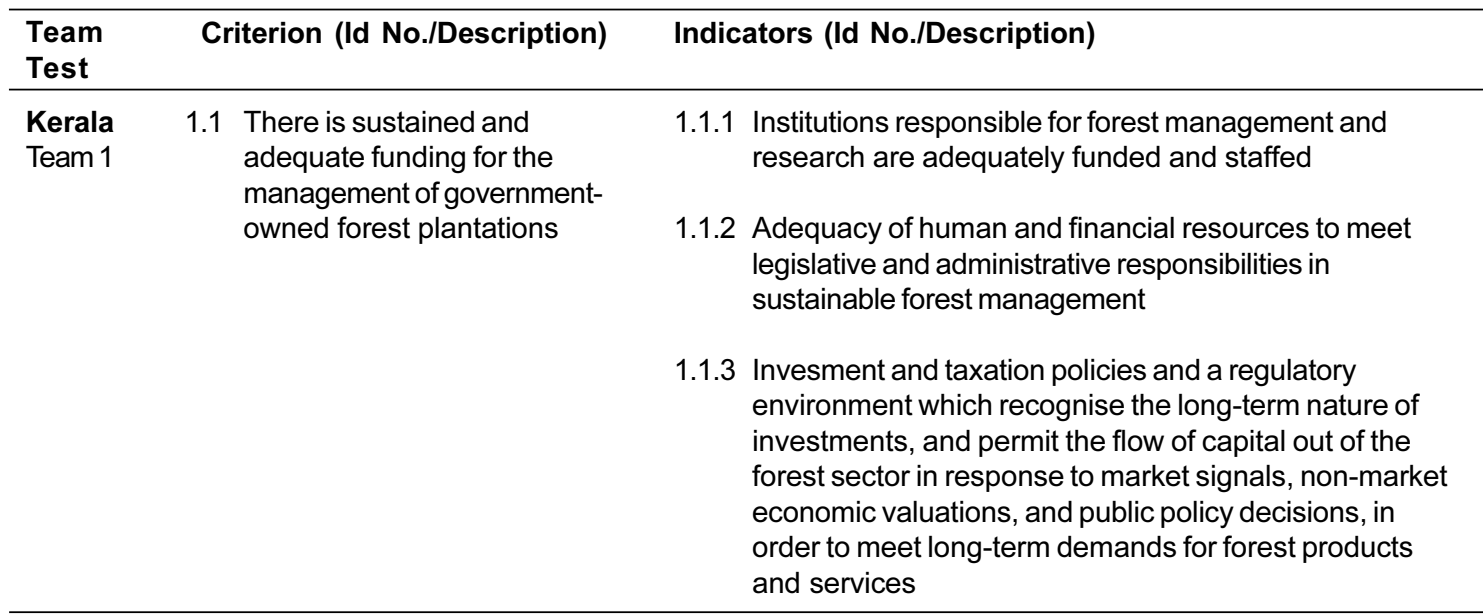

Kerala

Team 2
1.1 There is sustained and adequate funding for the management of government private and industry-owned forest plantations
1.1.1 Institutions responsible for forest management and research are adequately funded and staffed

1.1.2 Adequacy of human and financial resources to meet legislative and administrative responsibilities in sustainable forest management

1.1.3 Investment and taxation policies and a regulatory environment which recognise the long-term nature of invesmets and permit the flow of capital out of the forest sector in response to market signals, non-market economic valuations, and public policy decisions in order to meet long-term demands for forest products and services

\section{Bhopal}

Team 3

\section{Notes:}

All forest plantations in Kerala are government owned and hence Team 1 and Team 2 insisted on including the criteria on sustained and adequate funding. The two teams experienced lack of adequate and timely funding as one of the causes of mismanagement. In Madhya Pradesh the MPFDC is a corporation with more autonomy and access to public and private financial sources, so Team 3 did not consider this criterion as important. 
Table 8.3 Analysis of Commonalities

Policy - Criterion 1.2 (Bhopal)

\begin{tabular}{lcc}
\hline $\begin{array}{l}\text { Team } \\
\text { Test }\end{array}$ & Criterion (Id No./Description) & Indicators (Id No./Description) \\
\hline $\begin{array}{l}\text { Kerala } \\
\text { Team 1 }\end{array}$ & & \\
\hline $\begin{array}{l}\text { Kerala } \\
\text { Team 2 }\end{array}$ & & \\
\hline $\begin{array}{l}\text { Bhopal } \\
\text { Team 3 }\end{array}$ & $\begin{array}{r}1.2 \text { There exists adequate and trained } \\
\text { manpower in plantation forestry }\end{array}$ & $\begin{array}{l}1.2 .1 \text { Periodically of relevant training } \\
\text { programmes } \\
\text { (1.2.2 } \begin{array}{l}\text { Content of the training programme is } \\
\text { relevant }\end{array}\end{array}$ \\
\hline
\end{tabular}

Notes:

In Kerala, government forest departments and the forest service wholly manage forest plantations. It is a prerequisite for all staff to be trained in traditional forestry institutions prior to or after receiving employment. The MPFDC is independently recruits staff from the open market, hence Team 3 realised the importance of forestry training to field and executive staff.

At present, plantation management is done by staff trained in regular forestry training institutions. It is necessary to reorient this training to improve performance of the service.

Table 8.4 Analysis of Commonalities

Policy - Criterion 1.3 (Bhopal)

\begin{tabular}{lll}
\hline $\begin{array}{l}\text { Team } \\
\text { Test }\end{array}$ & Criterion (Id No./Description) & Indicators (Id No./Description) \\
\hline $\begin{array}{l}\text { Kerala } \\
\text { Team 1 }\end{array}$ & \\
\hline Kerala & \\
Team 2 & \\
\hline $\begin{array}{l}\text { Bhopal } \\
\text { Team 3 }\end{array}$ & $\begin{array}{l}\text { Information for forest resource accounting, } \\
\text { including that of plantation forests, is } \\
\text { available on a periodic basis }\end{array}$ & \\
\hline
\end{tabular}

Notes:

Forest working plans or management plans at the level of the forest division are revised every 10 years. They contain an evaluation of past management and resource accounting which enables corrections and improvements to be made. The Madhya Pradesh team retained criterion 1.3 with the intention of making the teak plantation business more scientific. 
Table 8.5 Analysis of Commonalities

Policy - Criterion 1.4 (Bhopal)

\begin{tabular}{lll}
\hline $\begin{array}{l}\text { Team } \\
\text { Test }\end{array}$ & Criterion (Id No./Description) & Indicators (Id No./Description) \\
\hline $\begin{array}{l}\text { Kerala } \\
\text { Team 1 }\end{array}$ & \\
\hline $\begin{array}{l}\text { Kerala } \\
\text { Team2 }\end{array}$ & \\
\hline $\begin{array}{l}\text { Bhopal } \\
\text { Team 3 }\end{array}$ & \begin{tabular}{l}
$1.4 \begin{array}{l}\text { Monitoring and evaluation of the plantation } \\
\text { projects and forest resource accounting } \\
\text { are carried out periodically }\end{array}$ \\
\hline
\end{tabular} \\
\hline
\end{tabular}

Notes:

It has been an age-old procedure in plantation forestry programmes to assess the resource base through inventories (Mean Annual Increment and Site Quality Assessment). These were conducted through working plans for each Forest Management Unit (division) every 10 years. At MPFDC this process is carried out more rigorously (once every 5 years) and the team felt that more relevant indicators and modern verifiers have to be evolved. The team felt that more time for case studies is required to undertake this mission.

Table 8.6 Analysis of Commonalities

Policy - Criterion 1.5 (Bhopal)

\begin{tabular}{lll}
\hline $\begin{array}{l}\text { Team } \\
\text { Test }\end{array}$ & Criterion (Id No./Description) & Indicators (Id No./Description) \\
\hline Kerala & \\
Team 1 & \\
\hline Kerala & \\
Team 2 & \\
\hline $\begin{array}{l}\text { Bhopal } \\
\text { Team 3 }\end{array}$ & $\begin{array}{l}\text { Reinvestment policies are conducive to } \\
\text { sustainable plantation management }\end{array}$ \\
\hline
\end{tabular}

Notes:

Proceeds of sales by public auction from plantation forestry programmes at present are credited to the State Exchequer. Departments are sometimes constrained in providing adequate funding to operations that enable sustainable plantation management. The Kerala teams took reinvestment policies as granted but the Bhopal team (because the test was conducted in the plantation of a corporation) felt the need to evolve firm reinvestment policies in this sector. 
Table 8.7 Analysis of Commonalities

Policy - Criterion 1.6 (Bhopal)

\begin{tabular}{|c|c|c|}
\hline $\begin{array}{l}\text { Team } \\
\text { Test }\end{array}$ & Criterion (Id No./Description) & Indicators (Id No./Description) \\
\hline $\begin{array}{l}\text { Kerala } \\
\text { Team } 1\end{array}$ & & \\
\hline $\begin{array}{l}\text { Kerala } \\
\text { Team } 2\end{array}$ & & \\
\hline $\begin{array}{l}\text { Bhopal } \\
\text { Team } 3\end{array}$ & $\begin{array}{l}\text { 1.6 Policy and legislation } \\
\text { encourage and efficiently } \\
\text { regulate the plantation forestry } \\
\text { business in the private sector }\end{array}$ & $\begin{array}{l}\text { 1.6.1 Land conversion, type of land and change in } \\
\text { cropping pattern are recorded } \\
\text { 1.6.2 Production targets, markets and financial goals are } \\
\text { stated } \\
\text { 1.6.3 Product quality is monitored } \\
\text { 1.6.4 There is provision for government intervention in } \\
\text { existing rules, taxation policies and the regulatory } \\
\text { environment }\end{array}$ \\
\hline
\end{tabular}

Notes:

There is an increasing interest in developing plantation forestry in the private sector to cater for the needs of woodbased industries. Certain regulations, both at national and FMU levels, for SFM are warranted. 
Table 9.1 Analysis of Commonalities

Ecology - Criterion 2.1 (Kerala)/2.4 (Bhopal)

\begin{tabular}{|c|c|c|}
\hline $\begin{array}{l}\text { Team } \\
\text { Test }\end{array}$ & Criterion (Id No./Description) & Indicators (Id No./Description) \\
\hline $\begin{array}{l}\text { Kerala } \\
\text { Team } 1\end{array}$ & $\begin{array}{l}2.1 \text { Impacts on } \\
\text { biodiversity of the } \\
\text { forest landscape } \\
\text { are minimised }\end{array}$ & 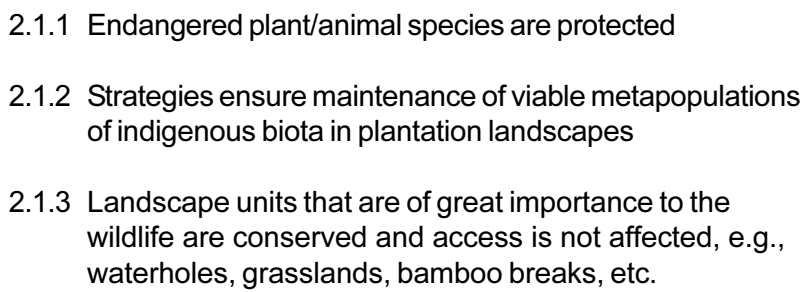 \\
\hline $\begin{array}{l}\text { Kerala } \\
\text { Team } 2\end{array}$ & $\begin{array}{l}2.1 \text { Impacts on } \\
\text { biodiversity of the } \\
\text { forest landscape } \\
\text { are minimised }\end{array}$ & $\begin{array}{l}\text { 2.1.1 Endangered plant/animal species are protected } \\
\text { 2.1.2 Strategies ensure maintenance of viable metapopulations } \\
\text { of indigenous biota in plantation landscapes } \\
\text { 2.1.3 Landscape units that are of great importance to the } \\
\text { wildlife are conserved and access is not affected, e.g., } \\
\text { waterholes, grasslands, bamboo breaks, etc. }\end{array}$ \\
\hline $\begin{array}{l}\text { Bhopal } \\
\text { Team } 3\end{array}$ & $\begin{array}{l}2.4 \text { Adverse impact on } \\
\text { biodiversity of the } \\
\text { forest landscape is } \\
\text { minimised }\end{array}$ & $\begin{array}{l}\text { 2.4.1 Endangered plant/animal species are protected } \\
\text { 2.4.2 Strategies ensure maintenance of viable metapopulations } \\
\text { of indigenous biota in plantation landscapes }\end{array}$ \\
\hline
\end{tabular}

Notes:

In Kerala and Madhya Pradesh, natural forests with diversity both in species and landscapes are converted to monospecies commercial plantations. Hence the issue of adverse impacts on biodiversity assumes importance. In Kerala forest conservation relates back to the ban on establishing new plantations after clearfelling natural forests as early as 1982. In Madhya Pradesh, in contrast, new forest plantations have been established at the cost of natural forests. Therefore, while the Kerala team stressed any impact on biodiversity through establishment of plantations, the Bhopal team referred to adverse impacts only. 
Table 9.2 Analysis of Commonalities

Ecology - Criterion 2.2 (Kerala and Bhopal)

\begin{tabular}{|c|c|}
\hline $\begin{array}{l}\text { Team } \\
\text { Test }\end{array}$ & Criterion (Id No./Description) \\
\hline $\begin{array}{l}\text { Kerala } \\
\text { Team } 1\end{array}$ & $\begin{array}{l}\text { 2.2 Maintenance of the health and } \\
\text { vitality of teak plantation } \\
\text { ecosystems }\end{array}$ \\
\hline
\end{tabular}

Indicators (Id No./Description)

2.2.1 Protection of the plantation against fire, pests and diseases

2.2.2 Based on the identification of key biological areas, roughly $10 \%$ of the total area under forest management (not including stream or roadside buffers) is designated as a 'conservation zone', i.e., land or forest to be conserved in its natural state without logging

2.2.3 No chemical contamination of food chains and
ecosystems

2.2.4 Regulations for the introduction of single provenance/ clones

2.2.5 Minimisation of impacts of monocultures through mixed cropping

\begin{tabular}{|c|c|c|}
\hline $\begin{array}{l}\text { Kerala } \\
\text { Team } 2\end{array}$ & 2.2 & $\begin{array}{l}\text { Maintenance of the health and } \\
\text { vitality of eucalypt plantation } \\
\text { ecosystems }\end{array}$ \\
\hline
\end{tabular}

2.2.1 Protection of the plantation against fire, pests and deseases.

2.2.2 Based on the identification of key biological areas, roughly $10 \%$ of the total area under forest management (not including stream or roadside buffers) is designated as a 'conservation zone', i.e., land or forest to be conserved in its natural state without logging

2.2.3 No chemical contamination of food chains and ecosystems 2.2.4 Regulations for the introduction of single provenance/
clones

2.2.5 Minimisation of impacts of monocultures through mixed cropping

$\begin{array}{ll}\text { Bhopal } & 2.2 \begin{array}{l}\text { Maintenance of the health and } \\ \text { vitality of teak plantation } \\ \text { ecom 3 }\end{array} \\ & \text { ecosystems }\end{array}$

2.2.1 Protection of the plantation against fire, pests and deseases.
2.2.2 No chemical contamination of food chains and ecosystems

2.2.3 Genetic diversity of teak is maintained

Notes:

In plantations in Kerala, during the colonial period, patches of natural vegetation/forests were retained to guard against pests and diseases and fire and for providing a niche for flora and fauna. At present this practice has been dispensed with. At plantation sites of MPFDC, miscellaneous species are retained around compartments at a width of 20 metres. Aerial spraying, attempted earlier to control pests, is not practised at present because of possible contamination of the food chain. There were incidences of mass mortality of young cattle and poultry in the neighbourhood of plantations sprayed annually. In the Indian context, with high man-land ratio, local people participate in fire protection activities. Eucalypt plantations in Kerala are devastated by fungal diseases. As chemical control is not feasible, due to practical problems and environmental issues, the solution is only through developing disease-resistant clones. 
Table 9.3 Analysis of Commonalities

Ecology - Criterion 2.3 (Kerala and Bhopal)

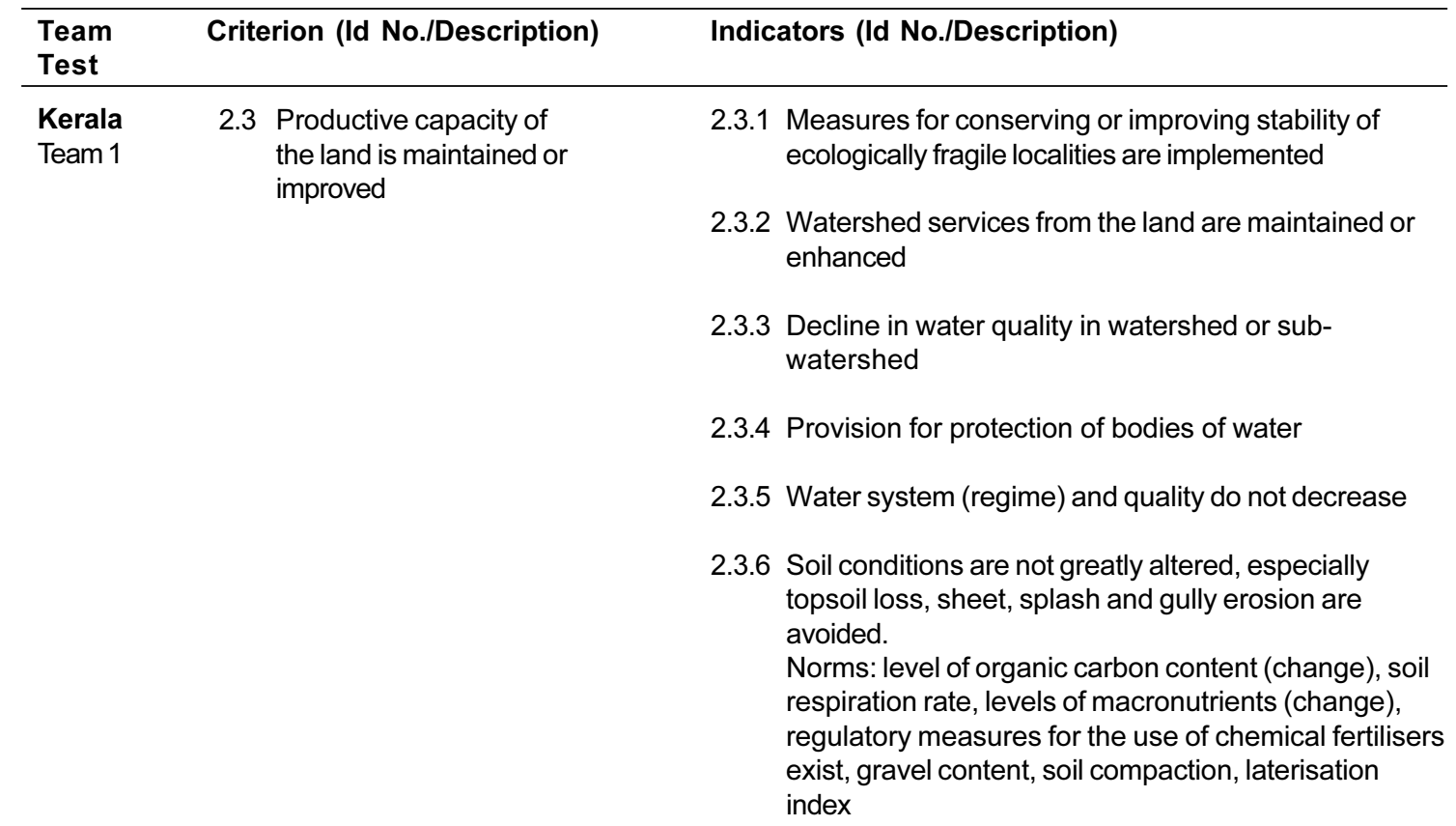

2.3.7 No inadvertent ponding or water logging as a result of forest management

Kerala 2.3 Productive capacity of Team 2 the land is maintained or improved
2.3.1 Measures for conserving or improving stability of ecologically fragile localities are implemented

2.3.2 Watershed services from the land are maintained or enhanced

2.3.3 Decline in water quality in watershed or subwatershed

\subsubsection{Provision for protection of bodies of water}

2.3.5 Water system (regime) and quality do not decrease

2.3.6 Soil conditions are not greatly altered, especially topsoil loss, sheet, splash and gully erosion are avoided.

Norms: level of organic carbon content (change), soil respiration rate, levels of macronutrients (change), regulatory measures for the use of chemical fertilisers exist, gravel content, soil compaction, laterisation index

2.3.7 No inadvertent ponding or water logging as a result of forest management

2.3.8 Nutrient losses due to short rotation are replenished on a scientific basis 
Table 9.3 (continued)

\begin{tabular}{lcc}
$\begin{array}{l}\text { Team } \\
\text { Test }\end{array}$ & Criterion (Id No./Description) & Indicators (Id No./Description) \\
\hline $\begin{array}{l}\text { Bhopal } \\
\text { Team } 3\end{array}$ & $\begin{array}{c}2.3 \text { Productive capacity of the land } \\
\text { is maintained or improved }\end{array}$ & $\begin{array}{l}2.3 .1 \\
\text { Optimal stocking (as per the management plan) so as } \\
\text { to minimise canopy opening }\end{array}$ \\
& $\begin{array}{c}2.3 .2 \begin{array}{l}\text { Measures for coserving or improving stability of } \\
\text { ecologically fragile localities are implemented }\end{array} \\
\text { 2.3.3 } \begin{array}{l}\text { Productive capacity of the soil is maintained or } \\
\text { improved }\end{array}\end{array}$ \\
\hline
\end{tabular}

Notes:

Sustainability of wood production over successive rotations has been of serious concern even during the British India period. Yield declines in second rotation plantations have been explained with reference to site quality, soil degradation, nutrient losses, etc. Therefore the three teams agreed on the need to implement mitigative measures at the FMU level in order to maintain and or improve the productive capacity of the site.

Table 9.4 Analysis of Commonalities

Ecology - Criterion 2.1 (Bhopal)

\begin{tabular}{lcr}
\hline $\begin{array}{l}\text { Team } \\
\text { Test }\end{array}$ & Criterion (Id No./Description) & Indicators (Id No./Description) \\
\hline $\begin{array}{l}\text { Kerala } \\
\text { Team } 1\end{array}$ & & \\
\hline $\begin{array}{l}\text { Kerala } \\
\text { Team 2 }\end{array}$ & & \\
\hline $\begin{array}{l}\text { Bhopal } \\
\text { Team 3 }\end{array}$ & $\begin{array}{l}\text { Areas under natural forests and } \\
\text { plantations are maintained or } \\
\text { improved }\end{array}$ & $\begin{array}{r}2.1 .1 \\
\text { In a given FMU, the percentage of plantations does } \\
\text { not exceed more than } 50 \% \text { of the forest land area }\end{array}$ \\
\hline
\end{tabular}

Notes:

In Madhya Pradesh plantation programmes are replacing natural forests at an increasing rate. Hence the indicator for preserving at least $50 \%$ of the area under natural forests in each FMU is relevant. Conservation of forests in Madhya Pradesh assumes great importance as the state controls more than $25 \%$ of the total forest area.

The bulk of the plantations (teak and eucalypt) in Kerala are of very low productivity. To increase production the only alternative is to improve the plantations already available, as there is a ban on establishing plantations by clearing natural forests.

Table 9.5 Analysis of Commonalities

Ecology - Criterion 2.5 (Bhopal)

\begin{tabular}{|c|c|c|}
\hline $\begin{array}{l}\text { Team } \\
\text { Test }\end{array}$ & Criterion (Id No./Description) & Indicators (Id No./Description) \\
\hline $\begin{array}{l}\text { Kerala } \\
\text { Team } 1\end{array}$ & & \\
\hline
\end{tabular}

Kerala

Team 2

\begin{tabular}{lll}
\hline $\begin{array}{l}\text { Bhopal } \\
\text { Team } 3\end{array}$ & $\begin{array}{l}2.5 \\
\text { Watershed functions of the land } \\
\text { are maintained or enhanced }\end{array}$ & 2.5 .1 Water quality is maintained or enhanced \\
\hline
\end{tabular}

Notes:

As Madhya Pradesh is a low-rainfall area, prone to periodic droughts and forest cover is a major part of the land use, watershed services in the forests assume great importance. 
Table 10.1 Analysis of Commonalities

Social - Criterion 3.1 (Kerala and Bhopal)

\begin{tabular}{|c|c|c|}
\hline Team & Criterion (Id No./Description) & Indicators (Id No./Description) \\
\hline \multirow[t]{8}{*}{$\begin{array}{l}\text { Kerala } \\
\text { Team } 1\end{array}$} & $\begin{array}{l}\text { 3.1 Local people accrue direct or } \\
\text { indirect benefits from the } \\
\text { plantation activities }\end{array}$ & $\begin{array}{l}\text { 3.1.1 Local people are given employment and promotion } \\
\text { opportunities }\end{array}$ \\
\hline & & 3.1.2 Local people are given training (job-oriented) \\
\hline & & $\begin{array}{l}\text { 3.1.3 Schools and educational facilities for local and other } \\
\text { employees }\end{array}$ \\
\hline & & $\begin{array}{l}\text { 3.1.4 Local and indigenous people are given preference in } \\
\text { competitive bidding and are encouraged to take up } \\
\text { contract activities }\end{array}$ \\
\hline & & $\begin{array}{l}\text { 3.1.5 Supply of fuel for employees and locals under the } \\
\text { collective management programme }\end{array}$ \\
\hline & & $\begin{array}{l}\text { 3.1.6 Water conservation/water distribution facilities equally } \\
\text { benefit employees and local people, either at a } \\
\text { concessional rate or free of cost }\end{array}$ \\
\hline & & $\begin{array}{l}\text { 3.1.7 Road and other communication systems are accessible } \\
\text { to local people as well }\end{array}$ \\
\hline & & $\begin{array}{l}\text { 3.1.8 Local food security is not affected because of plantation } \\
\text { extension }\end{array}$ \\
\hline
\end{tabular}

Kerala

Team2
3.1 Local people accrue direct or indirect benefits from the plantation activities
3.1.1 Local people are given employment and promotion opportunities

3.1.2 Local people are given training (job-oriented)

3.1.3 Schools and educational facilities for local and other employees

3.1.4 Local and indigenous people are given preference in competitive bidding and are encouraged to take up contract activities

3.1.5 Supply of fuel for employees and locals under the collective management programme

3.1.6 Water conservation/water distribution facilities equally benefit employees and local people, either at a concessional rate or free of cost

3.1.7 Road and other communication systems are accessible to local people as well

3.1.8 Local food security is not affected because of plantation extension 
Table 10.1 (continued)

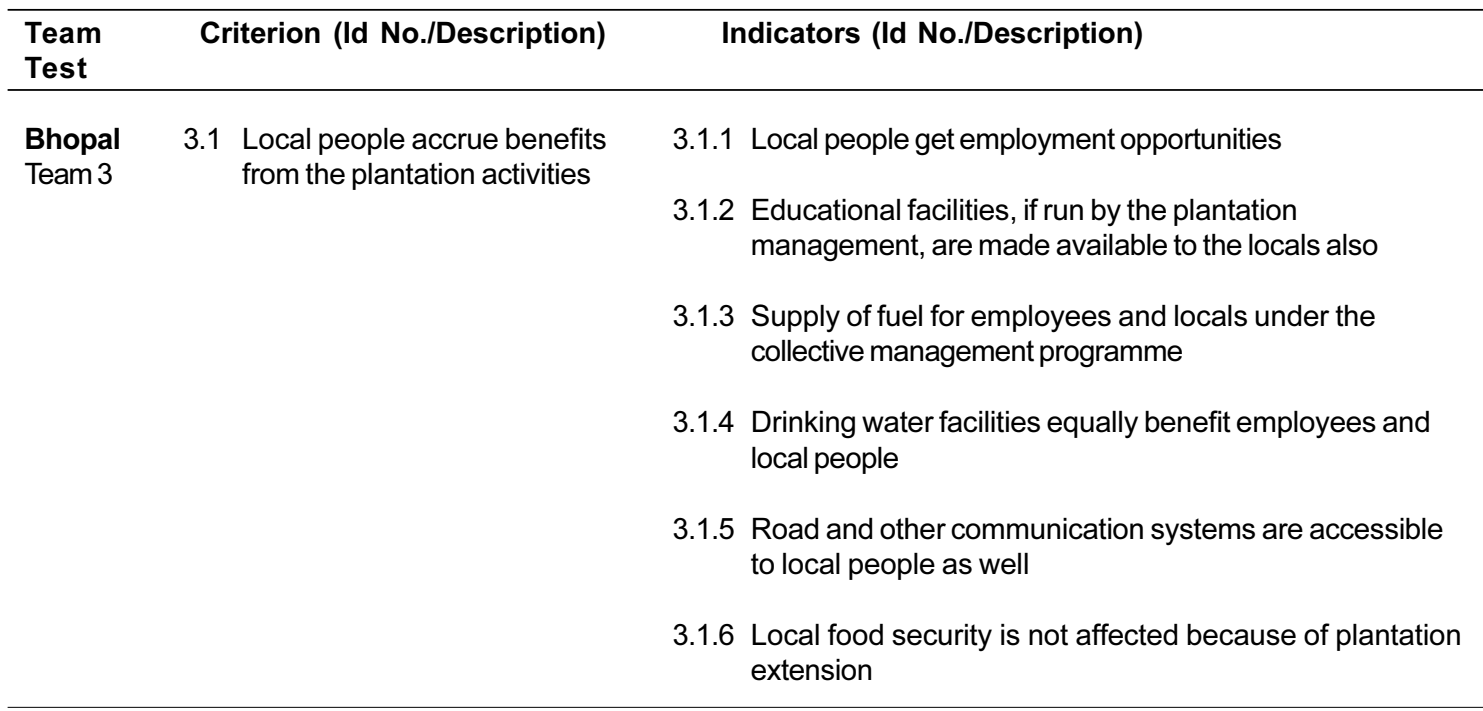

Notes:

In Kerala and Madhya Pradesh forest plantations are interpersed with human settlements. The population previously derived benefits from natural forests, which are now converted to plantations. Hence the need for ensuring more or less the same supply of benefits in the form of wages, goods and services. People settled in the fringes are the migrant group from Orissa and other parts of Madhya Pradesh, and were the labour force during the establishment of plantations by clearing natural forests. As the Forest Development Corporation is the only government agency working in the FMU it should assume responsibility for providing most of the social services, unlike in Kerala where different agencies for social advancement are active throughout.

Table 10.2 Analysis of Commonalities

Social - Criterion 3.2 (Kerala and Bhopal)

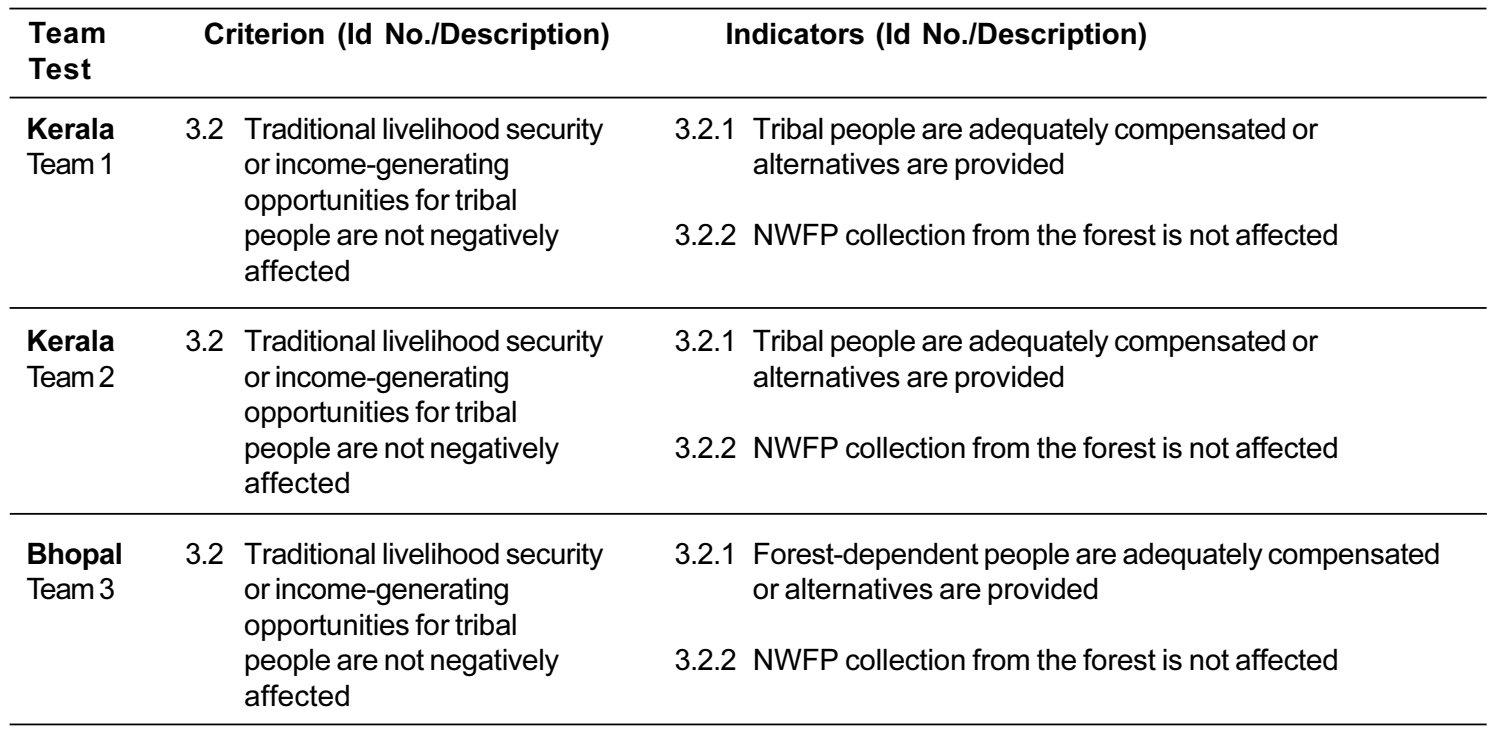

Notes:

In Kerala traditional rights to forest products lie with the tribal populations, who are issued permits. In Madhya Pradesh all stakeholders are permitted to extract forest products. 
Table 10.3 Analysis of Commonalities

Social - Criterion 3.3 (Kerala and Bhopal)

\begin{tabular}{lcc}
\hline $\begin{array}{l}\text { Team } \\
\text { Test }\end{array}$ & Criterion (Id No./Description) & Indicators (Id No./Description) \\
\hline $\begin{array}{l}\text { Kerala } \\
\text { Team 1 }\end{array}$ & $\begin{array}{c}3.3 \\
\begin{array}{l}\text { Labourers and employees are } \\
\text { compensated adequately and } \\
\text { their rights are protected }\end{array}\end{array}$ & $\begin{array}{c}3.3 .1 \\
\text { Periodic revision of employees' compensation } \\
\text { occurs }\end{array}$ \\
\hline $\begin{array}{l}\text { Kerala } \\
\text { Team } 2\end{array}$ & $3.3 \begin{array}{l}\text { Labourers and employees are } \\
\text { compensated adequately and } \\
\text { their rights are protected }\end{array}$ & 3.3 .2 Compliance with international or national labour rules \\
\hline $\begin{array}{l}\text { Bhopal } \\
\text { Team 3 }\end{array}$ & $\begin{array}{l}\text { occurs } \\
\text { compensated adequately and } \\
\text { their rights are protected }\end{array}$ & 3.3 .2 Compliance with international or national labour rules \\
\hline
\end{tabular}

Notes:

Trade union activities in forest labour are well organised and labour rules and regulations are implemented strictly. In Madhya Pradesh such a situation does not exist.

Table 10.4 Analysis of Commonalities Social - Criterion 3.4 (Kerala and Bhopal)

\begin{tabular}{|c|c|c|}
\hline $\begin{array}{l}\text { Team } \\
\text { Test }\end{array}$ & Criterion (Id No./Description) & Indicators (Id No./Description) \\
\hline $\begin{array}{l}\text { Kerala } \\
\text { Team } 1\end{array}$ & $\begin{array}{l}\text { 3.4 Tenure rights of the local } \\
\text { people are secure }\end{array}$ & $\begin{array}{l}\text { 3.4.1 No incidents of bullying and threats from plantation } \\
\text { authorities }\end{array}$ \\
\hline $\begin{array}{l}\text { Kerala } \\
\text { Team } 2\end{array}$ & $\begin{array}{l}\text { 3.4 Tenure rights of the local } \\
\text { people are secure }\end{array}$ & $\begin{array}{l}\text { 3.4.1 No incidents of bullying and threats from plantation } \\
\text { authorities }\end{array}$ \\
\hline $\begin{array}{l}\text { Bhopal } \\
\text { Team } 3\end{array}$ & $\begin{array}{l}\text { 3.4 Tenure rights of the local } \\
\text { people are secure }\end{array}$ & $\begin{array}{l}\text { 3.4.1 No incidents of bullying and threats from plantation } \\
\text { authorities }\end{array}$ \\
\hline
\end{tabular}


Table 10.5 Analysis of Commonalities

Social - Criterion 3.5 (Kerala and Bhopal)

\begin{tabular}{|c|c|c|}
\hline $\begin{array}{l}\text { Team } \\
\text { Test }\end{array}$ & Criterion (Id No./Description) & Indicators (Id No./Description) \\
\hline \multirow[t]{2}{*}{$\begin{array}{l}\text { Kerala } \\
\text { Team } 1\end{array}$} & $\begin{array}{l}3.5 \text { Indirect benefits from } \\
\text { tourism activities do } \\
\text { not have any hidden } \\
\text { social cost involved }\end{array}$ & $\begin{array}{l}\text { 3.5.1 Tourism activities associated with plantations do not affect } \\
\text { the local resource equity, displacement or marginalisation of } \\
\text { local or indigenous populations }\end{array}$ \\
\hline & & $\begin{array}{l}\text { 3.5.2 Plantation activities or other recreation facilities are not } \\
\text { gender discriminatory at the local level }\end{array}$ \\
\hline \multirow[t]{2}{*}{$\begin{array}{l}\text { Kerala } \\
\text { Team } 2\end{array}$} & $\begin{array}{l}3.5 \text { Indirect benefits from } \\
\text { tourism activities do } \\
\text { not have any hidden } \\
\text { social cost involved }\end{array}$ & $\begin{array}{l}\text { 3.5.1 Tourism activities associated with plantations do not affect } \\
\text { the local resource equity, and do not result in displacement } \\
\text { or marginalisation of local or indigenous populations }\end{array}$ \\
\hline & & $\begin{array}{l}\text { 3.5.2 Plantation activities or other recreation facilities are not } \\
\text { gender discriminatory at the local level }\end{array}$ \\
\hline \multirow[t]{2}{*}{$\begin{array}{l}\text { Bhopal } \\
\text { Team } 3\end{array}$} & $\begin{array}{l}3.5 \text { Indirect benefits from } \\
\text { tourism activities do } \\
\text { not have any hidden } \\
\text { social cost involved }\end{array}$ & $\begin{array}{l}\text { 3.5.1 Tourism activities associated with plantations do not affect } \\
\text { the local resource equity, and do not result in displacement } \\
\text { or marginalisation of local or indigenous populations }\end{array}$ \\
\hline & & $\begin{array}{l}\text { 3.5.2 Plantation activities or other recreation facilities are not } \\
\text { gender discriminatory at the local level }\end{array}$ \\
\hline
\end{tabular}

Notes:

Tourism activities are being spread into forest areas and plantation tourism can take away certain benefits enjoyed today by the local and tribal populations for the benefit of tour operators and tourists.

Table 10.6 Analysis of Commonalities

Social - Criterion 4.1 (Kerala)/3.6 (Bhopal)

\begin{tabular}{|c|c|c|}
\hline $\begin{array}{l}\text { Team } \\
\text { Test } \\
\end{array}$ & Criterion (Id No./Description) & Indicators (Id No./Description) \\
\hline $\begin{array}{l}\text { Kerala } \\
\text { Team } 1\end{array}$ & $\begin{array}{l}\text { 4.1 Plantation management } \\
\text { involves local people in } \\
\text { areas of common interest }\end{array}$ & $\begin{array}{l}\text { 4.1.1 Efficient maintenance of common wood lots } \\
\text { 4.1.2 Participation in fire protection } \\
\text { 4.1.3 Participation in watershed development programmes }\end{array}$ \\
\hline $\begin{array}{l}\text { Kerala } \\
\text { Team } 2\end{array}$ & $\begin{array}{l}\text { 4.1 Plantation management } \\
\text { involves local people in } \\
\text { areas of common interest }\end{array}$ & $\begin{array}{l}\text { 4.1.1 Efficient maintenance of common wood lots } \\
\text { 4.1.2 Participation in fire protection } \\
\text { 4.1.3 Participation in watershed development programmes }\end{array}$ \\
\hline $\begin{array}{l}\text { Bhopal } \\
\text { Team } 3\end{array}$ & $\begin{array}{l}\text { 3.6 Plantation management } \\
\text { involves local people in } \\
\text { areas of common interest }\end{array}$ & $\begin{array}{l}\text { 3.6.1 Efficient maintenance of common wood lots } \\
\text { 3.6.2 Participation in fire protection } \\
\text { 3.6.3 Participation in watershed development programmes } \\
\text { 3.6.4 Community participation in grazing control }\end{array}$ \\
\hline
\end{tabular}

Notes:

In Kerala, involvement of local people in maintenance of common wood lots, protection against fire and watershed development is a prerequisite to deriving goods and services from the forests. As grazing in forests is not a regular feature in Kerala as in Madhya Pradesh the indicator on grazing control refers to the latter state only. 
Table 11.1 Analysis of Commonalities

Management - Criterion 5.1 (Kerala)/4.1 (Bhopal)

\begin{tabular}{|c|c|c|}
\hline $\begin{array}{l}\text { Team } \\
\text { Test }\end{array}$ & Criterion (Id No./Description) & Indicators (Id No./Description) \\
\hline $\begin{array}{l}\text { Kerala } \\
\text { Team } 1\end{array}$ & $\begin{array}{l}\text { 5.1 Management objectives are } \\
\text { clearly and precisely described } \\
\text { and documented }\end{array}$ & $\begin{array}{l}\text { 5.1.1 Objectives are clearly stated in terms of major } \\
\text { functions of the plantation }\end{array}$ \\
\hline $\begin{array}{l}\text { Kerala } \\
\text { Team2 }\end{array}$ & $\begin{array}{l}\text { 5.1 Management objectives are } \\
\text { clearly and precisely described } \\
\text { and documented }\end{array}$ & $\begin{array}{l}\text { 5.1.1 Objectives are clearly stated in terms of major } \\
\text { functions of the plantation }\end{array}$ \\
\hline $\begin{array}{l}\text { Bhopal } \\
\text { Team } 3\end{array}$ & $\begin{array}{l}\text { 4.1 Management objectives are } \\
\text { clearly and precisely described } \\
\text { and documented }\end{array}$ & $\begin{array}{l}\text { 4.1.1 Objectives are clearly stated in terms of major } \\
\text { functions of the plantation }\end{array}$ \\
\hline
\end{tabular}

Notes:

Over the past 150 years forestry operations in India have been documented and managed through working plans and management plans.

Table 11.2 Analysis of Commonalities

Management - Criterion 5.2 (Kerala)/4.2 (Bhopal)

\begin{tabular}{|c|c|c|}
\hline $\begin{array}{l}\text { Team } \\
\text { Test }\end{array}$ & Criterion (Id No./Description) & Indicators (Id No./Description) \\
\hline $\begin{array}{l}\text { Kerala } \\
\text { Team } 1\end{array}$ & $\begin{array}{l}\text { 5.2 A comprehensive management } \\
\text { plan exists, which ensures the } \\
\text { economic and ecological } \\
\text { sustainability of the teak } \\
\text { plantation }\end{array}$ & $\begin{array}{l}\text { 5.2.1 A management plan is available } \\
\text { 5.2.2 Yield management plans ensure economic viability } \\
\text { 5.2.3 Marketing strategies avoid gluts in the market } \\
\text { 5.2.4 Management plans to ameliorate or counter natural } \\
\text { catastrophes (e.g., fires) and planning responses } \\
\text { for resource stabilisation and recovery } \\
\text { 5.2.5 Harvest regulation plans minimise adverse } \\
\text { environmental impacts }\end{array}$ \\
\hline $\begin{array}{l}\text { Kerala } \\
\text { Team2 }\end{array}$ & $\begin{array}{l}\text { 5.2 A comprehensive management } \\
\text { plan exists, which ensures the } \\
\text { economic and ecological } \\
\text { sustainability of the eucalypt } \\
\text { plantation }\end{array}$ & $\begin{array}{l}\text { 5.2.1 A management plan is available } \\
\text { 5.2.2 Yield management plans ensure economic viability } \\
\text { 5.2.3 Marketing strategies avoid gluts in the market } \\
\text { 5.2.4 Management plans to ameliorate or counter natural } \\
\text { catastrophes (e.g., fires) and planning responses } \\
\text { for resource stabilisation and recovery } \\
\text { 5.2.5 Harvest regulation plans minimise adverse } \\
\text { environmental impacts }\end{array}$ \\
\hline
\end{tabular}


Table 11.2 (continued)

\begin{tabular}{|c|c|c|}
\hline $\begin{array}{l}\text { Team } \\
\text { Test }\end{array}$ & Criterion (Id No./Description) & Indicators (Id No./Description) \\
\hline $\begin{array}{l}\text { Bhopal } \\
\text { Team } 3\end{array}$ & $\begin{array}{l}\text { 4.2 A comprehensive management } \\
\text { plan exists, which ensures the } \\
\text { economic and ecological } \\
\text { sustainability of the teak } \\
\text { plantation }\end{array}$ & $\begin{array}{l}\text { 4.2.1 A management plan is available } \\
\text { 4.2.2 Yield management plans ensure economic viability } \\
\text { 4.2.3 Marketing strategies avoid gluts in the market } \\
\text { 4.2.4 Management plans to ameliorate or counter natural } \\
\text { catastrophes (e.g., fires) and planning responses for } \\
\text { resource stabilisation and recovery }\end{array}$ \\
\hline
\end{tabular}

Notes:

Eucalypt wood is supplied to the industry at subsidised rates, a practice which has to be dispensed with. Teak wood from plantations is sold at open auction and hence prices are determined by national demand and supply scenarios.

Table 11.3 Analysis of Commonalities Management - Criterion 5.3 (Kerala)/4.3 (Bhopal)

\begin{tabular}{|c|c|c|}
\hline $\begin{array}{l}\text { Team } \\
\text { Test }\end{array}$ & Criterion (Id No./Description) & Indicators (Id No./Description) \\
\hline \multirow[t]{5}{*}{$\begin{array}{l}\text { Kerala } \\
\text { Team } 1\end{array}$} & $\begin{array}{l}\text { 5.3 The management plan is } \\
\text { effectively implemented }\end{array}$ & $\begin{array}{l}\text { 5.3.1 Harvest efficiency and product utilisation ensure } \\
\text { economic sustainability }\end{array}$ \\
\hline & & 5.3.2 Reduced-impact felling specified/implemented \\
\hline & & $\begin{array}{l}\text { 5.3.3 Sustainable timber production (in quality and } \\
\text { quantity) is guaranteed }\end{array}$ \\
\hline & & 5.3.4 Skidding damage to trees and soil is minimised \\
\hline & & $\begin{array}{l}\text { 5.3.5 Forest management minimises impacts of logging on } \\
\text { plantation's structure and biodiversity }\end{array}$ \\
\hline \multirow[t]{5}{*}{$\begin{array}{l}\text { Kerala } \\
\text { Team } 2\end{array}$} & $\begin{array}{l}\text { 5.3 The management plan is } \\
\text { effectively implemented }\end{array}$ & $\begin{array}{l}\text { 5.3.1 Harvest efficiency and product utilisation ensure } \\
\text { economic sustainability }\end{array}$ \\
\hline & & 5.3.2 Reduced-impact felling specified/implemented \\
\hline & & $\begin{array}{l}\text { 5.3.3 Sustainable timber production (in quality and } \\
\text { quantity) is guaranteed }\end{array}$ \\
\hline & & 5.3.4 Skidding damage to trees and soil is minimised \\
\hline & & $\begin{array}{l}\text { 5.3.5 Forest management minimises impacts of logging on } \\
\text { plantation's structure and biodiversity }\end{array}$ \\
\hline
\end{tabular}


Table 11.3 (continued)

\begin{tabular}{|c|c|c|}
\hline $\begin{array}{l}\text { Team } \\
\text { Test }\end{array}$ & Criterion (Id No./Description) & Indicators (Id No./Description) \\
\hline \multirow[t]{5}{*}{$\begin{array}{l}\text { Bhopal } \\
\text { Team } 3\end{array}$} & $\begin{array}{l}\text { 4.3 The management plan is } \\
\text { effectively implemented }\end{array}$ & $\begin{array}{l}\text { 4.3.1 Harvest efficiency and product utilisation ensure } \\
\text { economic sustainability }\end{array}$ \\
\hline & & 4.3.2 Reduced-impact felling specified/implemented \\
\hline & & $\begin{array}{l}\text { 4.3.3 Sustainable timber production (in quality and quantity) } \\
\text { is guaranteed }\end{array}$ \\
\hline & & 4.3.4 Skidding damage to trees and soil is minimised \\
\hline & & $\begin{array}{l}\text { 4.3.5 Forest management minimises impacts of logging on } \\
\text { plantation's structure and biodiversity }\end{array}$ \\
\hline
\end{tabular}

Notes:

Working plans and management plans are revised every ten years on the basis of evaluation of past performances and future needs.

Table 11.4 Analysis of Commonalities

Management - Criterion 5.4 (Kerala)/4.4 (Bhopal)

\begin{tabular}{|c|c|c|}
\hline $\begin{array}{l}\text { Team } \\
\text { Test }\end{array}$ & Criterion (Id No./Description) & Indicators (Id No./Description) \\
\hline $\begin{array}{l}\text { Kerala } \\
\text { Team } 1\end{array}$ & $\begin{array}{l}\text { 5.4 An efficient monitoring and } \\
\text { control system is present to } \\
\text { periodically revise management } \\
\text { prescriptions based on new } \\
\text { information }\end{array}$ & $\begin{array}{l}\text { 5.4.1 Documentation and records of all management } \\
\text { activities are kept in a form that makes it possible for } \\
\text { monitoring to occur }\end{array}$ \\
\hline $\begin{array}{l}\text { Kerala } \\
\text { Team2 }\end{array}$ & $\begin{array}{l}5.4 \text { An efficient monitoring and } \\
\text { control system is present to } \\
\text { periodically revise management } \\
\text { prescriptions based on new } \\
\text { information }\end{array}$ & 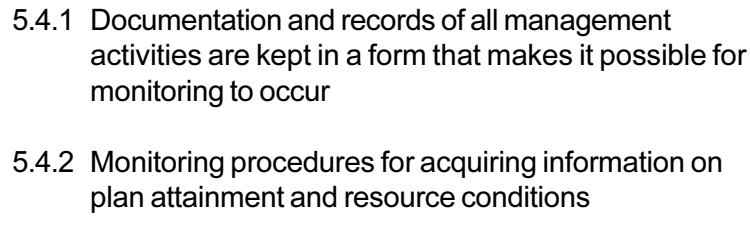 \\
\hline $\begin{array}{l}\text { Bhopal } \\
\text { Team 3 }\end{array}$ & $\begin{array}{l}\text { 4.4 An efficient monitoring and } \\
\text { control system is present to } \\
\text { periodically revise management } \\
\text { prescriptions based on new } \\
\text { information }\end{array}$ & $\begin{array}{l}\text { 4.4.1 Documentation and records of all management } \\
\text { activities are kept in a form that makes it possible for } \\
\text { monitoring to occur }\end{array}$ \\
\hline
\end{tabular}

Notes:

Working plans revised every ten years also serve monitoring purposes. 


\subsection{Sources of the final sets of Principles, Criteria, Indicators and Verifiers proposed by the three teams}

The sets of PCIV proposed by the teams to be field tested at each site are listed in Annexes 3.1 to 3.3. Included in these tables are the comments by the teams related to the original source (Reference) and the nature of any modifications to the C\&I as part of the IFGM field evaluation process conducted at each site.

The sources of the PCIV for Kerala and Madhya Pradesh are summarised in Tables 12 and 13. Results demonstrate the importance of the IFGM process of field testing C\&I that indicates where these may need to be modified and adapted to address those issues most relevant to plantations in Kerala and Madhya Pradesh. In Kerala the contribution from KFRI consisted of one principle, 5 criteria, 29 indicators and 44 verifiers (Table 12). In Madhya Pradesh BIP-KFRI provided one principle, 7 criteria, 15 indicators and 14 verifiers, while KFRI contributed 7 criteria, 19 indicators and 34 verifiers. The most exciting feature is the attempt to produce possible verifiers, as the Indian teams comprised a combination of experienced foresters, ecologists and social scientists. Only $38 \%$ of PCIV were drawn from other sources.

\subsection{Synthesis of common Criteria and Indicators proposed by the three teams}

The process of synthesising a core set of C\&I was based on identification of commonalities between the site-specific sets proposed by the teams. Indicators were classified into three categories: common (selected by all teams), semi-common (selected by two teams), and unique (selected by one team only). Results of this comparison (Table 14) also include indicators that were newly formulated during the field tests.

A high proportion of policy indicators proposed by Team 3 in Madhya Pradesh were unique (Table 14) and this reflects differences in forest policies and organisations responsible for managing plantations in the two states (see Tables 8.1-8.7). Likewise, a number of ecology indicators addressed specific local issues and were therefore classed as unique (see Tables 9.1-9.5). In contrast, a large proportion of socio-economic indicators were common reflecting the similarity in social issues between the test sites (see Tables 10.1-10.6). Management issues were common at all sites, this is consistent with the historical development of plantation forestry in the two states.

Based on this comparison of site-specific C\&I, a core set was formulated with C\&I common for the three sites (Table 15). This set of C\&I is considered to be more widely applicable to plantations across India.

Table 12. Sources of PCIV in plantations in Kerala

\begin{tabular}{|c|c|c|c|c|c|c|c|c|}
\hline & \multicolumn{2}{|c|}{ Principles } & \multicolumn{2}{|c|}{ Criteria } & \multicolumn{2}{|c|}{ Indicators } & \multicolumn{2}{|c|}{ Verifiers } \\
\hline & $\begin{array}{c}\text { New/ } \\
\text { Unchanged }\end{array}$ & $\begin{array}{l}\text { Refor- } \\
\text { mulated }\end{array}$ & $\begin{array}{c}\text { New/ } \\
\text { Unchanged }\end{array}$ & $\begin{array}{l}\text { Refor- } \\
\text { mulated }\end{array}$ & $\begin{array}{c}\text { New/ } \\
\text { Unchanged }\end{array}$ & $\begin{array}{l}\text { Refor- } \\
\text { mulated }\end{array}$ & $\begin{array}{c}\text { New/ } \\
\text { Unchanged }\end{array}$ & $\begin{array}{l}\text { Refor- } \\
\text { mulated }\end{array}$ \\
\hline KFRI & 1 & - & 5 & - & 29 & - & 44 & - \\
\hline CIFOR & - & 3 & 2 & 2 & 6 & 1 & 5 & - \\
\hline Montreal & - & - & 1 & 1 & 1 & - & 7 & - \\
\hline ATO & - & 1 & - & 1 & 1 & - & 1 & 1 \\
\hline SWP & - & - & - & 1 & 1 & 3 & 4 & 1 \\
\hline $\mathrm{ACT}$ & - & - & - & - & - & - & 1 & - \\
\hline SCS & - & - & - & - & - & 1 & 4 & 1 \\
\hline ІाTO & - & - & - & - & - & - & 2 & 2 \\
\hline SA & - & - & - & - & - & 5 & - & 2 \\
\hline Indonesia & - & - & - & - & - & - & 1 & - \\
\hline Côte d'Ivoire & - & - & - & - & 1 & - & - & - \\
\hline FSC & - & - & - & 2 & - & - & - & 1 \\
\hline Total & 1 & 4 & 8 & 7 & 39 & 10 & 69 & 8 \\
\hline
\end{tabular}


Table 12. Sources of PCIV in plantations in Kerala

\begin{tabular}{|c|c|c|c|c|c|c|c|c|c|c|c|c|}
\hline & \multicolumn{3}{|c|}{ Principles } & \multicolumn{3}{|c|}{ Criteria } & \multicolumn{3}{|c|}{ Indicators } & \multicolumn{3}{|c|}{ Verifiers } \\
\hline & $\mathrm{N}$ & U & $\mathrm{R}$ & $\mathrm{N}$ & $U$ & $\mathrm{R}$ & $\mathrm{N}$ & $U$ & $\mathrm{R}$ & $N$ & U & $\mathrm{R}$ \\
\hline KFRI & 1 & - & - & 1 & - & - & 1 & - & - & 1 & - & - \\
\hline CIFOR & - & 3 & 3 & - & 3 & 3 & - & 3 & 3 & - & 3 & 3 \\
\hline Montreal & - & - & - & - & - & - & - & - & - & - & - & - \\
\hline ATO & - & 1 & 1 & - & 1 & 1 & - & 1 & 1 & - & 1 & 1 \\
\hline SWP & - & - & - & - & - & - & - & - & - & - & - & - \\
\hline ACT & - & - & - & - & - & - & - & - & - & - & - & - \\
\hline SCS & - & - & - & - & - & - & - & - & - & - & - & - \\
\hline ITTO & - & - & - & - & - & - & - & - & - & - & - & - \\
\hline SA & - & - & - & - & - & - & - & - & - & - & - & - \\
\hline Indonesia & - & - & - & - & - & - & - & - & - & - & - & - \\
\hline Côte d'Ivoire & - & - & - & - & - & - & - & - & - & - & - & _ \\
\hline $\mathrm{FSC}$ & - & - & _ & - & - & $\ldots$ & - & - & _- & - & - & - \\
\hline Total & 1 & 4 & 4 & 1 & 4 & 4 & 1 & 4 & 4 & 1 & 4 & 4 \\
\hline
\end{tabular}

N: New; U: Unchanged; R: Reformulated

Table 13. Sources of PCIV in plantations in Madhya Pradesh

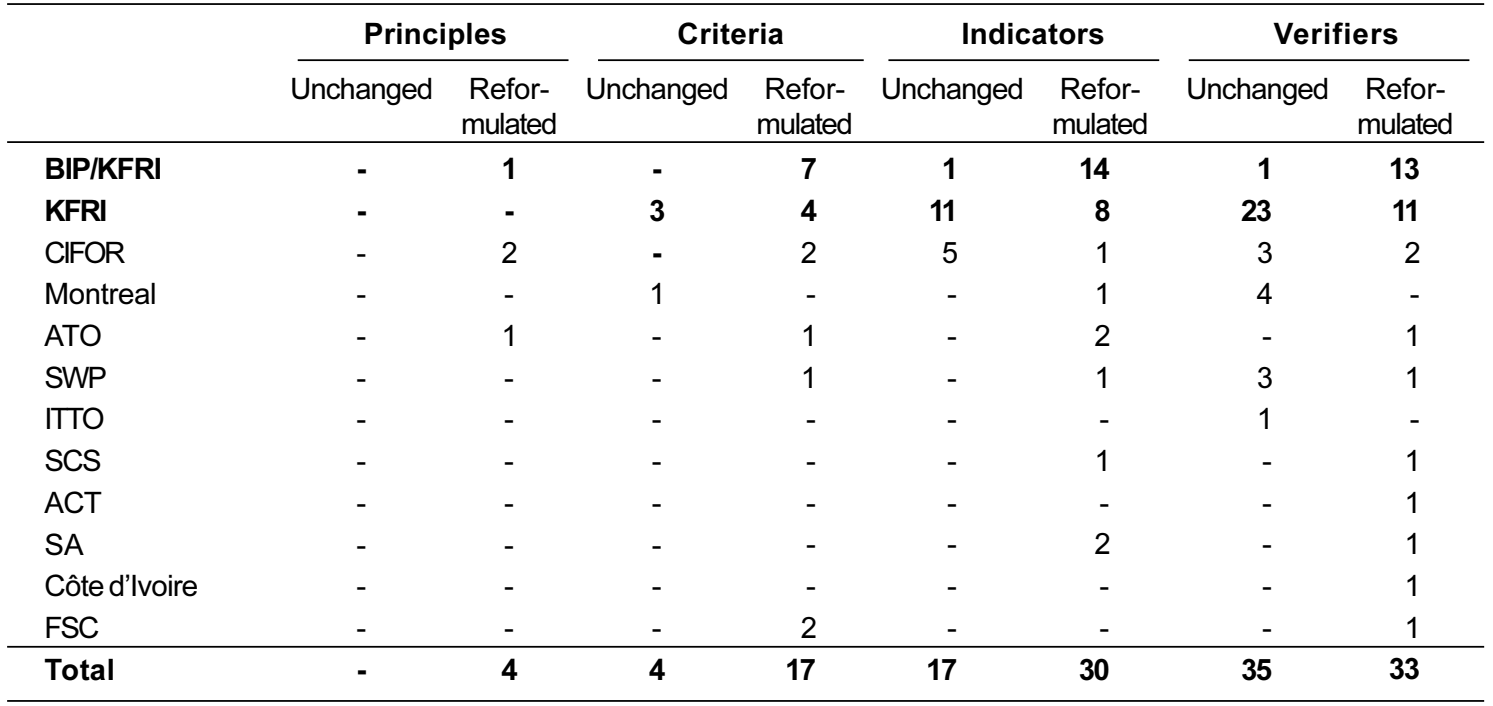

Table 14. Level of commonalty of C\&I for the compiled final set

\begin{tabular}{lcccc}
\hline & Policy & Ecology & Social & Management \\
\hline Common & - & 6 & 17 & 17 \\
Semi-common & 4 & 5 & 1 & - \\
Unique & 13 & 7 & 6 & - \\
New & - & 1 & 1 & - \\
\hline Total & $\mathbf{1 7}$ & $\mathbf{1 9}$ & $\mathbf{2 5}$ & $\mathbf{1 7}$ \\
\hline
\end{tabular}


Table 15. Final set of criteria and indicators of sustainable management for tropical plantation forests in India

\begin{tabular}{|c|c|c|c|}
\hline $\mathrm{C}$ & T1 & T2 & T3 \\
\hline \multicolumn{4}{|l|}{ Policy } \\
\hline $\begin{array}{l}\text { Planning and institutional frameworks are conducive to sustainable } \\
\text { management of forest plantations }\end{array}$ & & & * \\
\hline There exists policy and legal frameworks for plantation land use & & & * \\
\hline $\begin{array}{l}\text { There is sustained and adequate funding for the management of } \\
\text { government-owned forest plantations }\end{array}$ & * & * & \\
\hline $\begin{array}{l}\text { Institutions responsible for forest management and research are } \\
\text { adequately funded and staffed }\end{array}$ & * & * & \\
\hline $\begin{array}{l}\text { Adequacy of human and financial resources to meet legislative and } \\
\text { administrative responsibilities in sustainable forest management }\end{array}$ & * & * & \\
\hline $\begin{array}{l}\text { Investment and taxation policies and a regulatory environment which } \\
\text { recognise the long-term nature of investments and permit the flow of } \\
\text { capital out of the forest sector in response to market signals, non-market } \\
\text { economic valuations, and public policy decisions in order to meet long- } \\
\text { term demands for forest products and services }\end{array}$ & * & * & \\
\hline There exists adequate and trained manpower in plantation forestry & & & * \\
\hline Periodicity of relevant training programmes & & & * \\
\hline Content of the training programme is relevant & & & * \\
\hline $\begin{array}{l}\text { Information for forest resource accounting, including that of plantation } \\
\text { forests, is available on a periodic basis }\end{array}$ & & & * \\
\hline Management plans are user-friendly & & & * \\
\hline $\begin{array}{l}\text { Monitoring and evaluation of the plantation projects and forest } \\
\text { resource accounting are carried out periodically }\end{array}$ & & & * \\
\hline $\begin{array}{l}\text { Reinvestment policies are conducive to sustainable plantation } \\
\text { management }\end{array}$ & & & * \\
\hline $\begin{array}{l}\text { Policy and legislation encourage and efficiently regulate the plantation } \\
\text { forestry business in the private sector }\end{array}$ & & & * \\
\hline $\begin{array}{l}\text { Land conversion, type of land and change in cropping pattern are } \\
\text { recorded }\end{array}$ & & & * \\
\hline Production targets, markets and financial goals are stated & & & * \\
\hline Product quality is monitored & & & * \\
\hline $\begin{array}{l}\text { There is provision for government intervention in existing rules, taxation } \\
\text { policies and the regulatory environment }\end{array}$ & & & * \\
\hline
\end{tabular}


Table 15. Continued

\begin{tabular}{|c|c|c|c|}
\hline C & T1 & T2 & T3 \\
\hline \multicolumn{4}{|l|}{ Ecology } \\
\hline $\begin{array}{l}\text { Ecosystem integrity of the plantation-dominated forest landscape } \\
\text { is maintained }\end{array}$ & \multicolumn{3}{|c|}{ New } \\
\hline Impacts on biodiversity of the forest landscape are minimised & * & * & \\
\hline Endangered plant/animal species are protected & * & * & * \\
\hline $\begin{array}{l}\text { Strategies to ensure maintenance of viable metapopulations of indigenous } \\
\text { biota in plantation landscapes }\end{array}$ & * & * & * \\
\hline $\begin{array}{l}\text { Landscape units that are of great importance to the wildlife are } \\
\text { conserved and access is not affected, e.g., waterholes. grasslands, } \\
\text { bamboo breaks, etc. }\end{array}$ & * & * & \\
\hline $\begin{array}{l}\text { Area under natural forests on ridges, steep slopes and swamps has to } \\
\text { be maintained or improved }\end{array}$ & \multicolumn{3}{|c|}{ New } \\
\hline Maintenance of the health and vitality of plantation ecosystems & * & * & * \\
\hline Protection of the plantation against fire, pests and diseases & * & * & * \\
\hline $\begin{array}{l}\text { Based on the identification of key biological areas, roughly } 10 \% \text { of the } \\
\text { total area under forest management (not including stream or roadside } \\
\text { buffers) is designated as a 'conservation zone', i.e., land or forest to be } \\
\text { conserved in its natural state without logging }\end{array}$ & * & * & \\
\hline No chemical contamination of food chains and ecosystems & * & * & * \\
\hline Regulations for the introduction of single provenance/clones & * & * & \\
\hline Minimisation of impacts of monocultures through mixed cropping & * & * & \\
\hline Genetic diversity is maintained & & & * \\
\hline Productive capacity of the land is maintained or improved & * & * & * \\
\hline $\begin{array}{l}\text { Optimal stocking (as per the management plan) so as to minimise canopy } \\
\text { opening }\end{array}$ & & & * \\
\hline $\begin{array}{l}\text { Measures for conserving or improving stability of ecologically fragile } \\
\text { localities are implemented }\end{array}$ & * & * & * \\
\hline Nutrient losses due to short rotations are replenished on a scientific basis & & * & \\
\hline No inadvertent ponding or water logging as a result of forest management & * & * & \\
\hline Watershed functions of the land are maintained or enhanced & & & * \\
\hline Water quality is maintained or enhanced & & & * \\
\hline
\end{tabular}


Table 15. Continued

\begin{tabular}{|c|c|c|c|}
\hline $\mathrm{P} \quad \mathrm{C}$ & $\mathrm{T} 1$ & T2 & T3 \\
\hline \multicolumn{4}{|l|}{ Social } \\
\hline Socio-economic benefits are maintained or enhanced & & & * \\
\hline Local people accrue benefits from plantation activities & & & * \\
\hline $\begin{array}{l}\text { Local people, both men and women, get employment and promotion } \\
\text { opportunities }\end{array}$ & * & * & * \\
\hline Local people are given training (job-oriented) & * & * & \\
\hline $\begin{array}{l}\text { Educational facilities, if run by the plantation management, are made } \\
\text { available to the locals also }\end{array}$ & & & * \\
\hline $\begin{array}{l}\text { Supply of fuel for employees and locals under collective management } \\
\text { programme }\end{array}$ & * & * & * \\
\hline $\begin{array}{l}\text { Drinking water facilities, both quality and quantity, equally benefit } \\
\text { employees and local people }\end{array}$ & & & * \\
\hline $\begin{array}{l}\text { Road and other communication systems are accessible to local people as } \\
\text { well }\end{array}$ & * & * & * \\
\hline Local food security is not affected because of plantation extension & * & * & * \\
\hline $\begin{array}{l}\text { Village communities within plantations also enjoy the facilities available to } \\
\text { revenue-receiving villages }\end{array}$ & & New & \\
\hline $\begin{array}{l}\text { Traditional livelihood security or income-generation opportunities of } \\
\text { tribal people are not adversely affected }\end{array}$ & * & * & * \\
\hline $\begin{array}{l}\text { Forest-dependent people are adequately compensated or alternatives are } \\
\text { provided }\end{array}$ & & & * \\
\hline NWFP collection from the forest is not affected & * & * & * \\
\hline $\begin{array}{l}\text { Labourers and employees are compensated adequately and their } \\
\text { rights are protected }\end{array}$ & * & * & * \\
\hline Periodic wage revision occurs & & & * \\
\hline International/national labour rules are implemented & * & * & * \\
\hline Tenure rights of the local people are secure & * & * & * \\
\hline No incidents of bullying and threats from plantation authorities & * & * & * \\
\hline $\begin{array}{l}\text { Indirect benefits from tourism activities do not have any hidden social } \\
\text { cost involved }\end{array}$ & * & * & * \\
\hline $\begin{array}{l}\text { Tourism activities associated with plantations do not affect the local } \\
\text { resource equity, and do not result in displacement or marginalisation of the } \\
\text { local or indigenous populations }\end{array}$ & * & * & * \\
\hline $\begin{array}{l}\text { Plantation activities or other recreation facilities are not gender } \\
\text { discriminatory at the local level }\end{array}$ & * & * & * \\
\hline
\end{tabular}


Table 15. Continued

\begin{tabular}{|c|c|c|c|}
\hline P C I & T1 & T2 & T3 \\
\hline \multicolumn{3}{|l|}{} \\
\hline $\begin{array}{l}\text { Plantation management involves local people in areas of common } \\
\text { interest }\end{array}$ & $*$ & $*$ & $*$ \\
\hline Efficient maintenance of common wood lots & $*$ & $*$ & $*$ \\
\hline Participation in fire protection & $*$ & $*$ & $*$ \\
\hline Participation in watershed development programmes & $*$ & $*$ & $*$ \\
\hline Community participation in grazing control & & & $*$ \\
\hline
\end{tabular}


Table 15. Continued

\begin{tabular}{|c|c|c|c|}
\hline C & T1 & T2 & T3 \\
\hline \multicolumn{4}{|l|}{ Management } \\
\hline Yield and quality of forest products and services are improved & & & * \\
\hline $\begin{array}{l}\text { Management objectives are clearly and precisely described and } \\
\text { documented }\end{array}$ & * & * & * \\
\hline Objectives are clearly stated in terms of major functions of the plantation & * & * & * \\
\hline $\begin{array}{l}\text { A comprehensive management plan exists, which ensures the } \\
\text { economic and ecological sustainability of the plantation }\end{array}$ & * & * & * \\
\hline A management plan is available & * & * & * \\
\hline Yield management plans ensure economic viability & * & * & * \\
\hline Marketing strategies avoid gluts in the market & * & * & * \\
\hline $\begin{array}{l}\text { Management plans to ameliorate or counter natural catastrophes (e.g., } \\
\text { fires) and planning responses for resources stabilisation and recovery }\end{array}$ & * & * & * \\
\hline Harvest regulation plans minimise adverse environmental impacts & * & * & * \\
\hline The management plan is effectively implemented & * & * & * \\
\hline Harvest efficiency and product utilisation ensures economic sustainability & * & * & * \\
\hline Reduced-impact felling specified/implemented & * & * & * \\
\hline Sustainable timber production (in quality and quantity) is guaranteed & * & * & * \\
\hline Skidding damage to trees and soil is minimised & * & * & * \\
\hline $\begin{array}{l}\text { Forest management minimises impacts of logging on plantation's structure } \\
\text { and biodiversity }\end{array}$ & * & * & * \\
\hline $\begin{array}{l}\text { An efficient monitoring and control system is present to periodically } \\
\text { revise management prescriptions based on new information }\end{array}$ & * & * & * \\
\hline $\begin{array}{l}\text { Documentation and records of all management activities are kept in a form } \\
\text { that makes it possible for monitoring to occur }\end{array}$ & * & * & * \\
\hline $\begin{array}{l}\text { Monitoring procedures for acquiring information on plan attainment and } \\
\text { resource conditions }\end{array}$ & * & * & * \\
\hline
\end{tabular}




\section{Conclusions}

The project provided an opportunity for forestry scientists, forest managers, local communities and NGOs in Kerala and Madhya Pradesh to participate in the testing and evaluation of C\&I of sustainable management of plantations based on the IFGM process developed by CIFOR.

The selection of candidate sets of C\&I during stage 1 of the IFGM process, from the vast array of published information (in excess of $1000 \mathrm{C} \& \mathrm{I}$ ), was found to be time consuming and tedious by all three teams. This was due to a number of factors including:

- many published sets of C\&I were developed for natural forests;

- lack of consistency in hierarchical structure between published sets of C\&I; and

- C\&I were broadly defined, overlapping and difficult to apply at the FMU level.

The teams found it necessary to first group all C\&I under four principles: policy and planning, ecology, socio-economic and management. These C\&I groups were then further divided into subgroups before starting the selection process (Filter 1) to identify the candidate sets for field testing.

Field testing of C\&I based on stage 2 of the IFGM process evolved and teams became more proficient during the two tests conducted in Kerala. The third test in Madhya Pradesh was more effective because of the experience gained from the earlier tests in Kerala.
Stakeholder participation during the field tests and final workshops was invited. Local communities played an important role in shaping C\&I related to social and economic issues. During the final workshops a number of issues of concern to local communities and NGOs were identified including:

- impact of plantation development on water supplies to villages and settlements;

- loss of biodiversity and the long-term impact on NWFP collected by local communities to supplement income;

- sharing of benefits from plantation development to improve opportunities for schooling, training and employment; and

- environmental impacts, such as soil erosion and contamination.

The site-specific C\&I developed by the three teams were examined for commonalities and this formed the basis for a core set of C\&I applicable to the three sites included in this project. This core set is considered to be more widely applicable to plantation forestry in India. However, this evaluation also identified a number of unique C\&I addressing policy, ecological and social issues. This demonstrates the importance of testing and evaluating C\&I at the FMU level to ensure that local issues pertaining to the sustainable management of forest plantations are addressed. 


\section{References}

Bhopal-India Process. 1999. Bhopal India process for sustainable management of Indian forests. Indian Institute of Forest Management, Bhopal, Madhya Pradesh, India.

Prabhu, R., Colfer, C.J. Pierce, Venkateswarlu, P., Lay Cheng Tan, Rinekso Soekmadi and Wollenberg, E. 1996. Testing criteria and indicators for the sustainable management of forests: Phase 1. Final Report. CIFOR, Bogor, Indonesia.

Prabhu, R., Maynard, W., Ebaá Atyi, R., Colfer, C.J. Pierce, Shepherd, G., Venkateswarlu, P. and Tiayon, F. 1998. Testing and developing criteria and indicators for sustainable forest management in Cameroon: The Kribi Test Final Report. CIFOR, Bogor, Indonesia.
Prabhu, R., Colfer, C.J. Pierce and Dudley, R.G. 1999. Guidelines for developing, testing and selecting criteria and indicators for sustainable forest management. The Criteria and Indicators Toolbox Series No. 1. CIFOR, Bogor, Indonesia.

Wijewardena, D., Caswell, S.J. and PalmbergHerche, C. 1997. Criteria and indicators for sustainable forest management. Proceedings of the XI Forestry Congress 13-22 October, Antalya, Turkey. 


\title{
Annexes
}

\author{
Annex 1. Form 1
}

The objective of Filter 1 or response Form 1 is to provide a preliminary evaluation of all criteria and indicators to determine those most appropriate for assessing sustainability, based on professional judgement. This first examination should concentrate on eliminating only the most obviously deficient criteria and indicators. The result of this first evaluation is discussed with other team members to determine the set of C\&I considered by the team to be suitable for field evaluation. See Prabhu et al. (1999) for a detailed discussion of the purpose and application of Filter 1 of the IFGM procedure.

The following five questions have been designed to evaluate important attributes of criteria and indicators and to enable the elimination of obviously deficient criteria and indicators. A scale of 1-5 is used to rank criteria and indicators based on the following attributes and results are tabulated in Form 1 below.
1. Closely and unambiguously related to the assessment goal? Directly/obviously/ intuitively/logically linked to criterion or to sustainability

2. Easy to detect, record and interpret?

Easy to get the information, straightforward?

3. Provide a summary or integrative measure?

Summarises/integrates a lot of information, is it information efficient?

4. Adequate response range to changes in levels of stress?

Does the indicator continue to give you useful and meaningful information over a wide range of situations?

5. Is this item important and therefore selected as 'priority'?

Is it useful? Is it worth further investigation during the field phase?

\section{Form 1: Evaluation of Criteria and Indicators}

Please use a scale of $1=$ poor; $2=$ fair; $3=$ satisfactory; $4=$ good; $5=$ very good

\begin{tabular}{|l|c|c|c|c|c|c|}
\hline Source & $\begin{array}{c}\text { No. of C\&I as } \\
\text { printed in } \\
\text { source } \\
\text { document }\end{array}$ & $\begin{array}{c}\text { Class } \\
(\mathrm{P}, \mathrm{M}, \mathrm{E}, \mathrm{S}, \mathrm{F})\end{array}$ & $\begin{array}{c}\text { Closely and } \\
\text { unambiguously } \\
\text { related to the } \\
\text { assessment } \\
\text { goal? }\end{array}$ & $\begin{array}{c}\text { Easy to detect, } \\
\text { record and } \\
\text { interpret }\end{array}$ & $\begin{array}{c}\text { Provide a } \\
\text { summary or } \\
\text { integrative } \\
\text { measure? }\end{array}$ & $\begin{array}{c}\text { Important and } \\
\text { therefore } \\
\text { selected as } \\
\text { 'priority'? } \\
\text { Yes=1 No=0 }\end{array}$ \\
\hline & & & & & & \\
\hline & & & & & & \\
\hline & & & & & \\
\hline
\end{tabular}


Annex 2. Form 2

\section{TESTING CRITERIA AND INDICATORS: CIFOR METHOD} Form 2: Field Responses
EXPERT'S INITIALS

\section{P.C. Anil}
$\mathrm{A}=$
TEAMNO.
State source document
$\mathrm{B}=$
IDENTIFICATIONNO. IN SOURCE
$\mathrm{C}=$

FINAL IDENTIFICATION No. (As reported in Final List)
E Policy $=$ P, Social $=\mathrm{S}$, Production of

E Goods \& Services $=M$, Ecology $=E$, Financial \& Economic Aspects $=\mathrm{F}$

\section{CLASS}

Enter the selected criterion or indicator as stated in the source document in this space (use Box F for final vers.)

Protection of the plantation against fire, pests and diseases

Justify your selection of this criterion or indicator:

Fire, pests, and diseases are incidences common in teak plantations affecting productivity. The management measures adopted in each region involving local people and investments can be analysed.

ATTRIBUTES

Two entry boxes have been provided for each question in this section. The first box (a) refers to the criterion or indicator as listed in Box A, which is the initial selection. If the initial selection has to be modified, this will be recorded in Box F. This final version must be subjected to a renewal evaluation (f). By comparing evaluation (a) and (f) the reader can assess whether the final version is significantly better than the initial version.

Please use a scale of 1-5 when answering, where $1=$ no/bad/unimportant and $5=$ yes/good/important

\section{(a)(f)}

Provides a summary or integrative measure?

Closely and unambiguously related to the assesment goal?

Adequate response range to stresses? (Sensitive)

Diagnostically specific?

Appealing to users?

\section{\begin{tabular}{|l|l|}
\hline 5 & \\
\hline
\end{tabular}}

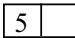

\begin{tabular}{|l|l|}
\hline 5 & \\
\hline
\end{tabular}

\begin{tabular}{|l|l|}
\hline 5 & \\
\hline
\end{tabular}

\begin{tabular}{|l|l|}
\hline 5 & \\
\hline
\end{tabular} (a)(f)

Easy to detect, record and interpret? Feasible Precisely defined? (clear)

Will it produce replicable results? (reliable)

How relevant is this criterion or indicator

Other

Provide bibliographic references (if any)

Give the ref. of C\&I in the Base Set (e.g. ATO) that overlaps (comes closest) to the criterion or indicator recommended above:

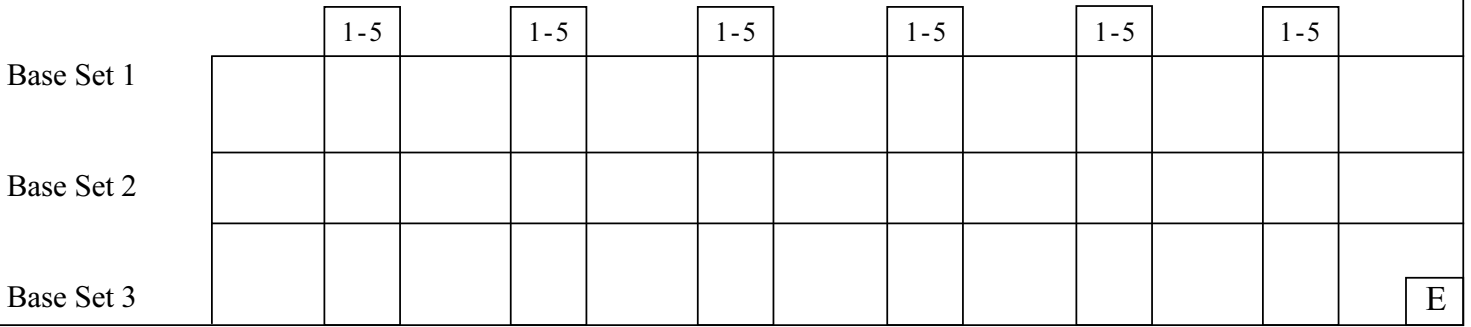




\section{Annex 2. Continued}

Final version of criterion/indicator, state only if different from definition in Box A:

Attempts were made to control fire with the participation of villagers/tribals living inside the forest. Pests were controlled earlier through aerial sprays but not attempted now. There is a green belt comprising other tree species along the border, dividing the plantations to minimise the pest attack and for easy movement.

Would this C\&I need to be evaluated

In the field?

In the office?

Both?

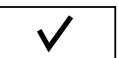

Please note below what kind of documentation would be required if the $C \& I$ were to be used in a proper field assessment of sustainable forest management

Forest Ranger's Office should have up to date records on

- Frequency of fire in the year

- Funds utilised to control fire, pest control

- Management strategies adopted, its strength, weakness, etc. 
Annex 2. Continued

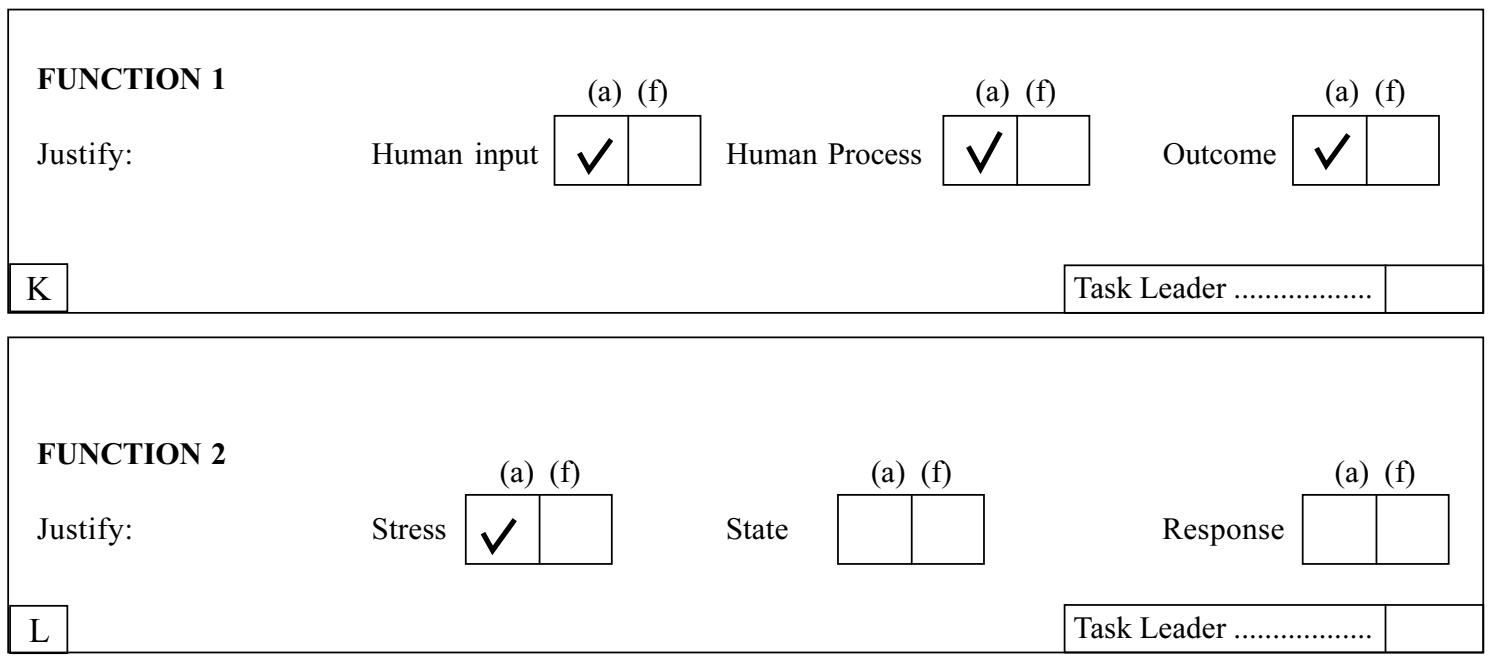

LINKAGES This criterion or indicator has an information value for the following areas/criteria/indicators:

Bio-physical:

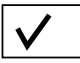

Social:

Management:

Other:

$\mathrm{M}$

Task Leader ...................

\section{WORKSHOP NOTES (For office use only)}

Did the workshop accept this criterion/indicator unchanged?

Why?

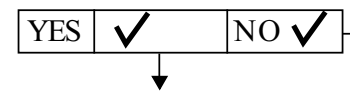

Were revisions called for? State version:

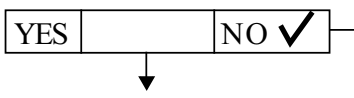

State justification for revision:

OR was this criterion or indicator rejected as being unsuitable?

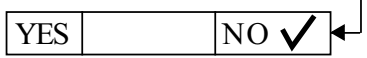

State reasons:

$\mathrm{N}$ 
Annex 3.1 Criteria and indicators of sustainable management for teak plantations in Kerala selected after field testing by Team 1.

\begin{tabular}{|c|l|l|l|l|l|l|}
\hline P & C & I & V & \multicolumn{2}{|c|}{ Description } & $\begin{array}{c}\text { Observation } \\
\text { Refer- } \\
\text { ence }\end{array}$ \\
\hline 1 & $\begin{array}{l}\text { Policy, planning and institutional frameworks are conducive to } \\
\text { sustainable management of teak plantation }\end{array}$ & Reformulated & CIFOR \\
\hline 1.1 & & & $\begin{array}{l}\text { There is sustained and adequate funding for the } \\
\text { management of government-owned forest } \\
\text { plantations }\end{array}$ & Reformulated & CIFOR \\
\hline & 1.1 .1 & & $\begin{array}{l}\text { Institutions responsible for forest management and } \\
\text { research are adequately funded and staffed }\end{array}$ & New & KFRI \\
\hline & 1.1 .2 & 1.1 .1 .1 & $\begin{array}{l}\text { Policy and planning are based on recent and accurate } \\
\text { information }\end{array}$ & Unchanged & CIFOR \\
\hline & 1.1 .3 & $\begin{array}{l}\text { Adequacy of human and financial resources to meet } \\
\text { legislative and administrarive responsibilities in sustainable } \\
\text { forest management }\end{array}$ & New & KFRI \\
\hline $\begin{array}{l}\text { Investment and taxation policies and a regulatory } \\
\text { environment which recognise the long-term nature of } \\
\text { investments and permit the flow of capital out of the forest } \\
\text { sector in response to market signals, non-market economic } \\
\text { valuations, and public policy decisions in order to meet long } \\
\text { term demands for forest products and services }\end{array}$ & Unchanged & Montreal \\
\end{tabular}


Annex 3.1 Continued

\begin{tabular}{|c|c|c|c|c|c|c|}
\hline $\mathrm{P}$ & $\mathrm{C}$ & I & V & Description & Observation & $\begin{array}{l}\text { Refer- } \\
\text { ence }\end{array}$ \\
\hline \multirow[t]{2}{*}{2} & \multicolumn{4}{|c|}{$\begin{array}{l}\text { The main ecological functions of the plantation teaks are } \\
\text { maintained }\end{array}$} & Reformulated & ATO \\
\hline & 2.1 & & & $\begin{array}{l}\text { Impacts on biodiversity of the forest landscape are } \\
\text { minimised }\end{array}$ & Unchanged & CIFOR \\
\hline & & 2.1 .1 & & Endangered plant/animal species are protected & Unchanged & CIFOR \\
\hline & & & 2.1.1.1 & $\begin{array}{l}\text { No tree of locally rare or endangered species or species } \\
\text { included in lists of sensitive species is felled }\end{array}$ & Unchanged & KFRI \\
\hline & & & 2.1.1.2 & $\begin{array}{l}\text { Floristically and faunistically rich patches of vegetation are } \\
\text { conserved }\end{array}$ & New & KFRI \\
\hline & & 2.1 .2 & & $\begin{array}{l}\text { Strategies to ensure maintenance of viable metapopulations } \\
\text { of indigenous biota in plantation landscapes }\end{array}$ & New & KFRI \\
\hline & & & 2.1.2.1 & $\begin{array}{l}\text { Indigenous and locally adapted species are permitted to } \\
\text { regenerate in gaps }\end{array}$ & New & KFRI \\
\hline & & & 2.1.2.2 & Corridors of unlogged forests are retained & Unchanged & CIFOR \\
\hline & & & 2.1.2.3 & $\begin{array}{l}\text { Raising plantations is not authorised if the vertical } \\
\text { stratification of a forest strip, which forms the wildlife } \\
\text { corridor, is disturbed }\end{array}$ & New & KFRI \\
\hline & & 2.1 .3 & & $\begin{array}{l}\text { Landscape units that are of great importance to wildlife are } \\
\text { conserved and access is not affected, e.g., waterholes, } \\
\text { grassland and bamboo breaks, etc. }\end{array}$ & New & KFRI \\
\hline & 2.2 & & & $\begin{array}{l}\text { Maintenance of health and vitality of forest } \\
\text { ecosystems }\end{array}$ & Unchanged & Montreal \\
\hline & & 2.2 .1 & & Protection of the plantation against fire & Unchanged & KFRI \\
\hline & & & 2.2.1.1 & Fire protection and control measures & New & KFRI \\
\hline & & 2.2 .2 & & $\begin{array}{l}\text { Based on the identification of key biological areas, roughly } \\
10 \% \text { of the total area under forest management (not } \\
\text { including stream or roadside buffers) is designated as a } \\
\text { 'conservation zone', i.e., land or forest to be conserved in } \\
\text { its natural state without logging }\end{array}$ & Unchanged & SWP \\
\hline & & & 2.2 .2 .1 & $\begin{array}{l}\text { Area and percentage of forest land with diminished } \\
\text { biological components indicative of changes in } \\
\text { fundamental ecological processes (e.g., soil nutrient } \\
\text { cycling, seed dispersion, pollination) and/or ecological } \\
\text { continuity (monitoring of functionally important species } \\
\text { such as fungi, arboreal epiphytes, nematodes, beetles and } \\
\text { wasps) }\end{array}$ & Unchanged & Montreal \\
\hline & & & 2.2 .2 .2 & $\begin{array}{l}\text { Observed circumstances in which ecologically important } \\
\text { areas were substantially altered through harvesting }\end{array}$ & Unchanged & SCS \\
\hline & & & 2.2.2.3 & $\begin{array}{l}\text { Conservation zone is preferably a contiguous blocks, } \\
\text { though it may be a series of smaller blocks linked by } \\
\text { corridors as wide as the average height of forest canopy in } \\
\text { mature forest (over } 75 \text { years) }\end{array}$ & Unchanged & SWP \\
\hline & & & 2.2 .2 .4 & $\begin{array}{l}\text { Special provisions for the protection of sensitive areas, } \\
\text { plains, stream banks, steep slopes should be defined in } \\
\text { management plan }\end{array}$ & Unchanged & ATO \\
\hline & & 2.2 .3 & & No chemical contamination of food chains and ecosystems & Unchanged & CIFOR \\
\hline
\end{tabular}


Annex 3.1 Continued

\begin{tabular}{|c|c|c|c|c|c|c|}
\hline$P$ & C & I & V & Description & Observation & $\begin{array}{l}\text { Refer- } \\
\text { ence }\end{array}$ \\
\hline & & & 2.2.3.1 & $\begin{array}{l}\text { Policies and procedures for proper use and disposal of } \\
\text { hazardous materials }\end{array}$ & Unchanged & SCS \\
\hline & & & 2.2.3.2 & $\begin{array}{l}\text { Extent to which silvicultural methods minimise the need for } \\
\text { pesticides (avoidance of cler cutting and other measures } \\
\text { designed to limit hardwood incursion) }\end{array}$ & Unchanged & Scs \\
\hline & & & 2.2.3.3 & Frequency of pesticide use and stated reasons for use & Unchanged & Scs \\
\hline & & & 2.2.3.4 & $\begin{array}{l}\text { Chemicals banned in Europe, America or the target } \\
\text { country are not used }\end{array}$ & Unchanged & $\begin{array}{l}\text { Indone- } \\
\text { sia }\end{array}$ \\
\hline & & & 2.2.3.5 & $\begin{array}{l}\text { Area and percentage of forest land experiencing an } \\
\text { accumulation of persistent toxic substances }\end{array}$ & Unchanged & Montreal \\
\hline & & & 2.2.3.6 & An integrated pest, disease and weed management plan & New & KFRI \\
\hline & & 2.2 .4 & & $\begin{array}{l}\text { Regulations for the introduction of single provenance/ } \\
\text { clones }\end{array}$ & New & KFRI \\
\hline & & & 2.2.4.1 & Use of only clones and provenances & New & KFRI \\
\hline & & & 2.2.4.2 & $\begin{array}{l}\text { Use of provenances well adapted to the site, having high } \\
\text { degree of disease and drought resistance }\end{array}$ & New & KFRI \\
\hline & & 2.2 .5 & & $\begin{array}{l}\text { Minimisation of impacts of monocultures through mixed } \\
\text { cropping }\end{array}$ & New & KFRI \\
\hline & 2.3 & & & $\begin{array}{l}\text { Productive capacity of the land is maintained or } \\
\text { improved }\end{array}$ & Reformulated & Montreal \\
\hline & & 2.3 .1 & & $\begin{array}{l}\text { Measures for conserving or improving stability of } \\
\text { ecologically fragile localities are implemented }\end{array}$ & New & KFRI \\
\hline & & & 2.3.1.1 & $\begin{array}{l}\text { Plantations prohibited on slopes of over } 30^{\circ} \text { measured } \\
\text { over a terrestrial distance of } 100 \mathrm{~m}\end{array}$ & New & KFRI \\
\hline & & & 2.3.1.2 & $\begin{array}{l}\text { Ecologically sensitive areas, especially buffer zones along } \\
\text { watercourses, are protected }\end{array}$ & Unchanged & CIFOR \\
\hline & & & 2.3.1.3 & $\begin{array}{l}\text { Shelter belts of natural vegetation are retained on the } \\
\text { ridges }\end{array}$ & New & KFRI \\
\hline & & 2.3 .2 & & $\begin{array}{l}\text { Watershed services from the land are maintained or } \\
\text { enhanced }\end{array}$ & New & KFRI \\
\hline & & & 2.3.2.1 & Water infiltration rate & New & KFRI \\
\hline & & 2.3 .3 & & Decline in water quality in watershed or sub-watershed & Unchanged & $\begin{array}{l}\text { Côte } \\
\text { d'Ivoire }\end{array}$ \\
\hline & & 2.3.4 & & Provision for protection of bodies of water & New & KFRI \\
\hline & & & 2.3.4.1 & $\begin{array}{l}\text { Percentage of stream kilometres in forested catchment in } \\
\text { which stream flow and timing has significantly deviated } \\
\text { from the historical range of variation }\end{array}$ & Unchanged & Montreal \\
\hline & & 2.3 .5 & & Water system (regime) and quality do not decrease & Unchanged & ATO \\
\hline & & & 2.3.5.1 & $\begin{array}{l}\text { Percentage of water bodies in forest areas (e.g., stream } \\
\text { kilometres, lake hectares) with significant variance of } \\
\text { biological diversity from the historical range of variability }\end{array}$ & Unchanged & Montreal \\
\hline & & & 2.3.5.2 & $\begin{array}{l}\text { Percentage of water bodies in forest areas (e.g., stream } \\
\text { kilometres, lake hectares) with significant variation from } \\
\text { the historical range of variability in } \mathrm{pH} \text {, dissolved oxygen, } \\
\text { levels of chemicals (electrical conductivity), sedimentation } \\
\text { or temperature change }\end{array}$ & Unchanged & Montreal \\
\hline
\end{tabular}




\section{Annex 3.1 Continued}

\begin{tabular}{|c|c|c|c|c|c|c|}
\hline P & C & I & V & Description & Observation & $\begin{array}{l}\text { Refer- } \\
\text { ence }\end{array}$ \\
\hline & & & 2.3.5.3 & Run-off regime is not altered & New & KFRI \\
\hline & & 2.3 .6 & & $\begin{array}{l}\text { Soil conditions are not greatly altered, especially topsoil } \\
\text { loss, sheet, splash and gully erosion, are avoided. Norms: } \\
\text { level of organic carbon content (change), soil respiration } \\
\text { rate, levels of macronutrients (change), regulatory } \\
\text { measures for the use of chemical fertiliser exist, gravel } \\
\text { content, soil compaction, laterisation index }\end{array}$ & New & KFRI \\
\hline & & & 2.3.6.1 & $\begin{array}{l}\text { Area and percentage of forest land with significant soil } \\
\text { erosion }\end{array}$ & Unchanged & Montreal \\
\hline & & & 2.3.6.2 & $\begin{array}{l}\text { Area and percentage of forest land with significantly } \\
\text { diminished soil organic matter and/or changes in other soil } \\
\text { chemical properties }\end{array}$ & Unchanged & Montreal \\
\hline & & & 2.3.6.3 & Soil conservation measures & Unchanged & ACT \\
\hline & & & 2.3.6.4 & Soil exposure & New & KFRI \\
\hline & & 2.3 .7 & & $\begin{array}{l}\text { No inadvertent ponding or water logging as a result of } \\
\text { forest management }\end{array}$ & Unchanged & CIFOR \\
\hline
\end{tabular}


Annex 3.1 Continued

\begin{tabular}{|c|c|c|c|c|c|c|}
\hline $\mathrm{P}$ & C & 1 & V & Description & Observation & $\begin{array}{l}\text { Refer- } \\
\text { ence }\end{array}$ \\
\hline \multicolumn{7}{|c|}{ SOCIAL } \\
\hline \multirow[t]{2}{*}{3} & \multicolumn{4}{|c|}{$\begin{array}{l}\text { Plantation establishment and management maintains or } \\
\text { enhances intergenerational access to resources, economic } \\
\text { benefits and infrastructural facilities for local people and other } \\
\text { plantation labourers }\end{array}$} & Reformulated & CIFOR \\
\hline & 3.1 & & & $\begin{array}{l}\text { Local people accrue direct or indirect benefits from } \\
\text { the plantation activities }\end{array}$ & New & KFRI \\
\hline & & 3.1 .1 & & $\begin{array}{l}\text { Local people, both men and women, get employment and } \\
\text { promotion opportunities }\end{array}$ & Reformulated & CIFOR \\
\hline & & & 3.1.1.1 & Proportion of local employees & New & KFRI \\
\hline & & & 3.1.1.2 & Reservation policies for locals exist and are followed & New & KFRI \\
\hline & & & 3.1.1.3 & $\begin{array}{l}\text { Proportion of/representation of officers in management } \\
\text { level }\end{array}$ & New & KFRI \\
\hline & & 3.1 .2 & & Local people are given training (job-oriented) & Reformulated & SA \\
\hline & & & 3.1.2.1 & $\begin{array}{l}\text { There is a regular locally relevant training programme or } \\
\text { skill development for locals run by the FMU }\end{array}$ & New & KFRI \\
\hline & & & 3.1.2.2 & The training programme is beneficial for locals & New & KFRI \\
\hline & & 3.1 .3 & & $\begin{array}{l}\text { Schools and educational facilities for local and other } \\
\text { employees }\end{array}$ & Reformulated & SA \\
\hline & & & 3.1.3.1 & Nature awareness programmes & New & KFRI \\
\hline & & & 3.1 .3 .2 & Student-teacher ratio & New & KFRI \\
\hline & & & 3.1.3.3 & Scholarships & New & KFRI \\
\hline & & 3.1 .4 & & $\begin{array}{l}\text { Local and indigenous people are given preference in } \\
\text { competitive bidding and are encouraged to take up contract } \\
\text { activities }\end{array}$ & New & KFRI \\
\hline & & & 3.1.4.1 & $\begin{array}{l}\text { Policy exists to give preference for locals in plantation } \\
\text { bidding }\end{array}$ & New & KFRI \\
\hline & & & 3.1 .4 .2 & Contractors are encouraged to employ locals & New & KFRI \\
\hline & & 3.1 .5 & & $\begin{array}{l}\text { Supply of fuel for employees and locals under collective } \\
\text { management programmes }\end{array}$ & New & KFRI \\
\hline & & & 3.1.5.1 & Cooking fuel & New & KFRI \\
\hline & & 3.1 .6 & & $\begin{array}{l}\text { Water conservation/water distribution facilities equally } \\
\text { benefit employees and local people, either at a } \\
\text { concessional rate or free of cost }\end{array}$ & New & KFRI \\
\hline & & & 3.1.6.1 & $\begin{array}{l}\text { There is a soil and water conservation programme } \\
\text { implemented by the FMU }\end{array}$ & New & KFRI \\
\hline & & & 3.1.6.2 & $\begin{array}{l}\text { Local people are educated on cost-effective and low-cost } \\
\text { soil and water conservation programmes }\end{array}$ & New & KFRI \\
\hline & & 3.1 .7 & & $\begin{array}{l}\text { Road and other communication systems are accessible to } \\
\text { local people as well }\end{array}$ & New & KFRI \\
\hline & & 3.1 .8 & & $\begin{array}{l}\text { Local food security is not affected because of plantation } \\
\text { extension }\end{array}$ & New & KFRI \\
\hline
\end{tabular}


Annex 3.1 Continued

\begin{tabular}{|c|c|c|c|c|c|c|}
\hline $\mathrm{P}$ & $\mathrm{C}$ & 1 & V & Description & Observation & $\begin{array}{l}\text { Refer- } \\
\text { ence }\end{array}$ \\
\hline & & & 3.1.8.1 & $\begin{array}{l}\text { Changes in cropping pattern to commercial crops following } \\
\text { plantation activities }\end{array}$ & New & KFRI \\
\hline & 3.2 & & & $\begin{array}{l}\text { Traditional livelihood security or income-generating } \\
\text { opportunities for people are not negatively affected }\end{array}$ & New & KFRI \\
\hline & & 3.2 .1 & & $\begin{array}{l}\text { Tribal people are adequately compensated or alternatives } \\
\text { are provided }\end{array}$ & New & KFRI \\
\hline & & & 3.2.1.1 & Details of resettlement & New & KFRI \\
\hline & & 3.2 .2 & & NWFP collection from the forest is not affected & & \\
\hline & 3.3 & & & $\begin{array}{l}\text { Labourers and employees are compensated } \\
\text { adequately and their rights are protected }\end{array}$ & Reformulated & SWP \\
\hline & & 3.3 .1 & & Periodic revision of employees' compensation occurs & Reformulated & SWP \\
\hline & & & 3.3.1.1 & Incidents of protests & New & KFRI \\
\hline & & 3.3 .2 & & Compliance with international or national labour rules & Reformulated & SA \\
\hline & & & 3.3.2.1 & Welfare schemes & New & KFRI \\
\hline & 3.4 & & & Tenure rights of the local people are secure & Reformulated & CIFOR \\
\hline & & 3.4 .1 & & $\begin{array}{l}\text { No incidents of bullying and threats from plantation } \\
\text { authorities }\end{array}$ & New & KFRI \\
\hline & & & 3.4.1.1 & Cases, rumours, etc. & New & KFRI \\
\hline & 3.5 & & & $\begin{array}{l}\text { Indirect benefits from tourism activities do not have } \\
\text { any hidden social cost involved }\end{array}$ & New & KFRI \\
\hline & & 3.5 .1 & & $\begin{array}{l}\text { Tourism activities associated with plantations do not affect } \\
\text { the local resource equity, displacement or marginalisation of } \\
\text { the local or indigenous populations }\end{array}$ & New & KFRI \\
\hline & & & 3.5.1.1 & Rise in land value & New & KFRI \\
\hline & & & 3.5.1.2 & Change in land use to urban & New & KFRI \\
\hline & & & 3.5.1.3 & $\begin{array}{l}\text { Privatisation of common water bodies, playing grounds or } \\
\text { pastoral lands }\end{array}$ & New & KFRI \\
\hline & & 3.5 .2 & & $\begin{array}{l}\text { Plantation activities or other recreation facilities are not } \\
\text { gender discriminatory at the local level }\end{array}$ & New & KFRI \\
\hline & & & 3.5.2.1 & Number of minor cases & New & KFRI \\
\hline \multirow[t]{5}{*}{4} & \multicolumn{4}{|c|}{$\begin{array}{l}\text { Stakeholders, including locals and forest actors, have a voice in } \\
\text { plantation management }\end{array}$} & Reformulated & CIFOR \\
\hline & 4.1 & & & $\begin{array}{l}\text { Plantation management involves local people in } \\
\text { areas of common interest }\end{array}$ & New & KFRI \\
\hline & & 4.1.1 & & Efficient maintenance of common wood lots & Reformulated & SWP \\
\hline & & 4.1 .2 & & Participation in fire protection & Reformulated & SA \\
\hline & & 4.1.3 & & Participation in watershed development programmes & New & KFRI \\
\hline
\end{tabular}


Annex 3.1 Continued

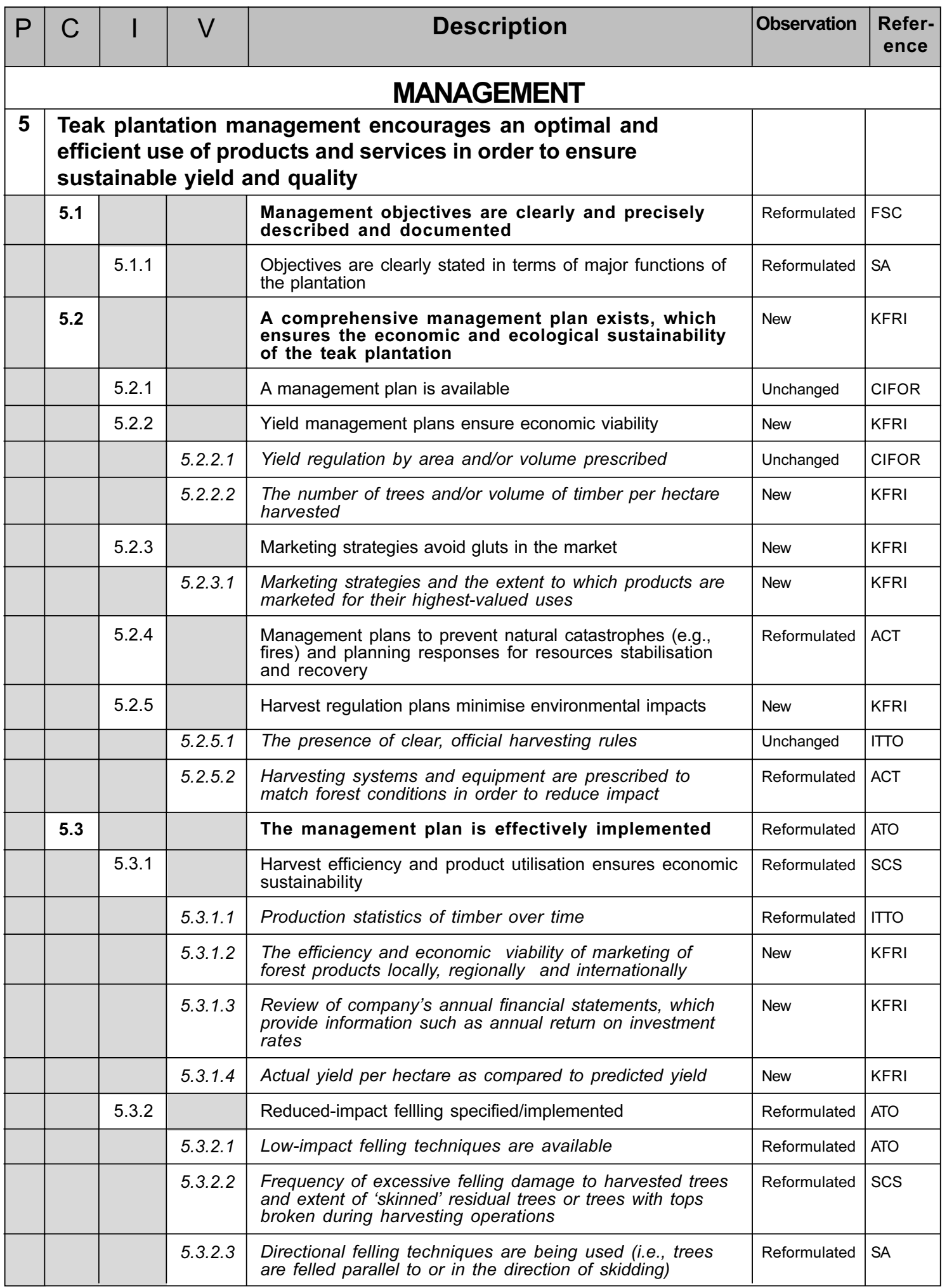




\section{Annex 3.1 Continued}

\begin{tabular}{|c|c|c|c|c|c|c|}
\hline $\mathrm{P}$ & C & I & V & Description & Observation & $\begin{array}{l}\text { Refer- } \\
\text { ence }\end{array}$ \\
\hline & & 5.3 .3 & & $\begin{array}{l}\text { Sustainable timber production (in quality and quantity) is } \\
\text { guaranteed }\end{array}$ & New & KFRI \\
\hline & & & 5.3.3.1 & $\begin{array}{l}\text { Silvicultural prescriptions (pre, during and post-harvest) } \\
\text { are being adhered to }\end{array}$ & New & KFRI \\
\hline & & & 5.3.3.2 & $\begin{array}{l}\text { Growth rates, stocking and regeneration are being } \\
\text { monitored by a suitable continuous forest inventory } \\
\text { system }\end{array}$ & Reformulated & FSC \\
\hline & & & 5.3.3.3 & $\begin{array}{l}\text { Extent to which expedient prescriptions such as diameter- } \\
\text { limit harvesting are routinely applied }\end{array}$ & New & KFRI \\
\hline & & & 5.3.3.4 & Harvest trees are marked prior to logging & Reformulated & ITTO \\
\hline & & & 5.3.3.5 & A pre-logging stand inventory & Unchanged & ITTO \\
\hline & & 5.3 .4 & & Skidding damage to trees and soil is mimised & Unchanged & CIFOR \\
\hline & & & 5.3.4.1 & $\begin{array}{l}\text { Front end of logs is lifted off ground during mechanical } \\
\text { skidding }\end{array}$ & Unchanged & SWP \\
\hline & & & 5.3 .4 .2 & Skid trail gradients do not exceed 25 degrees & Unchanged & SWP \\
\hline & & & 5.3.4.3 & $\begin{array}{l}\text { Specifications in terms of skid trail width and location have } \\
\text { been set and are being followed }\end{array}$ & Unchanged & SWP \\
\hline & & 5.3 .5 & & $\begin{array}{l}\text { Forest management minimises impacts of logging on } \\
\text { plantation's structure and biodiversity }\end{array}$ & New & KFRI \\
\hline & & & 5.3.5.1 & Canopy opening is minimised & Unchanged & CIFOR \\
\hline & 5.4 & & & $\begin{array}{l}\text { An efficient monitoring and control system is } \\
\text { present to periodically revise management } \\
\text { prescription based on new information }\end{array}$ & Reformulated & FSC \\
\hline & & 5.4 .1 & & $\begin{array}{l}\text { Documentation and records of all management activities are } \\
\text { kept in a form that makes it possible for monitoring to occur }\end{array}$ & Unchanged & CIFOR \\
\hline & & 5.4 .2 & & $\begin{array}{l}\text { Monitoring procedures for acquiring information on plan } \\
\text { attainment and resource conditions }\end{array}$ & New & KFRI \\
\hline & & & 5.4.2.1 & Records of annual areas cut over time & Reformulated & SWP \\
\hline & & & 5.4 .2 .2 & $\begin{array}{l}\text { Actual annual harvest levels as compared to planned } \\
\text { levels }\end{array}$ & New & KFRI \\
\hline & & & 5.4.2.3 & $\begin{array}{l}\text { Provision for monitoring the residual growing stock after } \\
\text { logging }\end{array}$ & New & KFRI \\
\hline
\end{tabular}


Annex 3.2 Criteria and indicators of sustainable management for eucalypt plantations in Kerala selected after field testing by Team 2 .

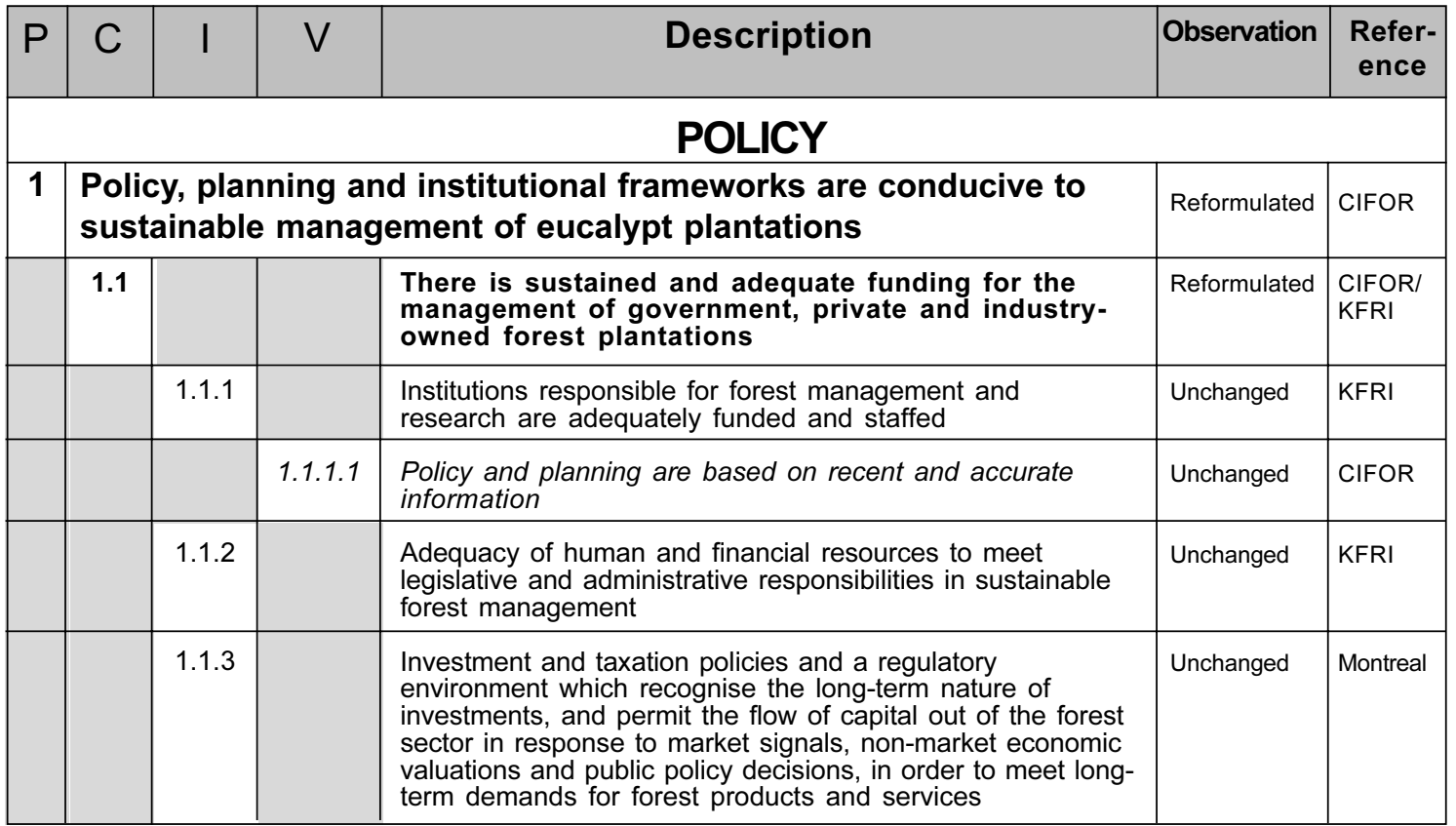


Annex 3.2 Continued

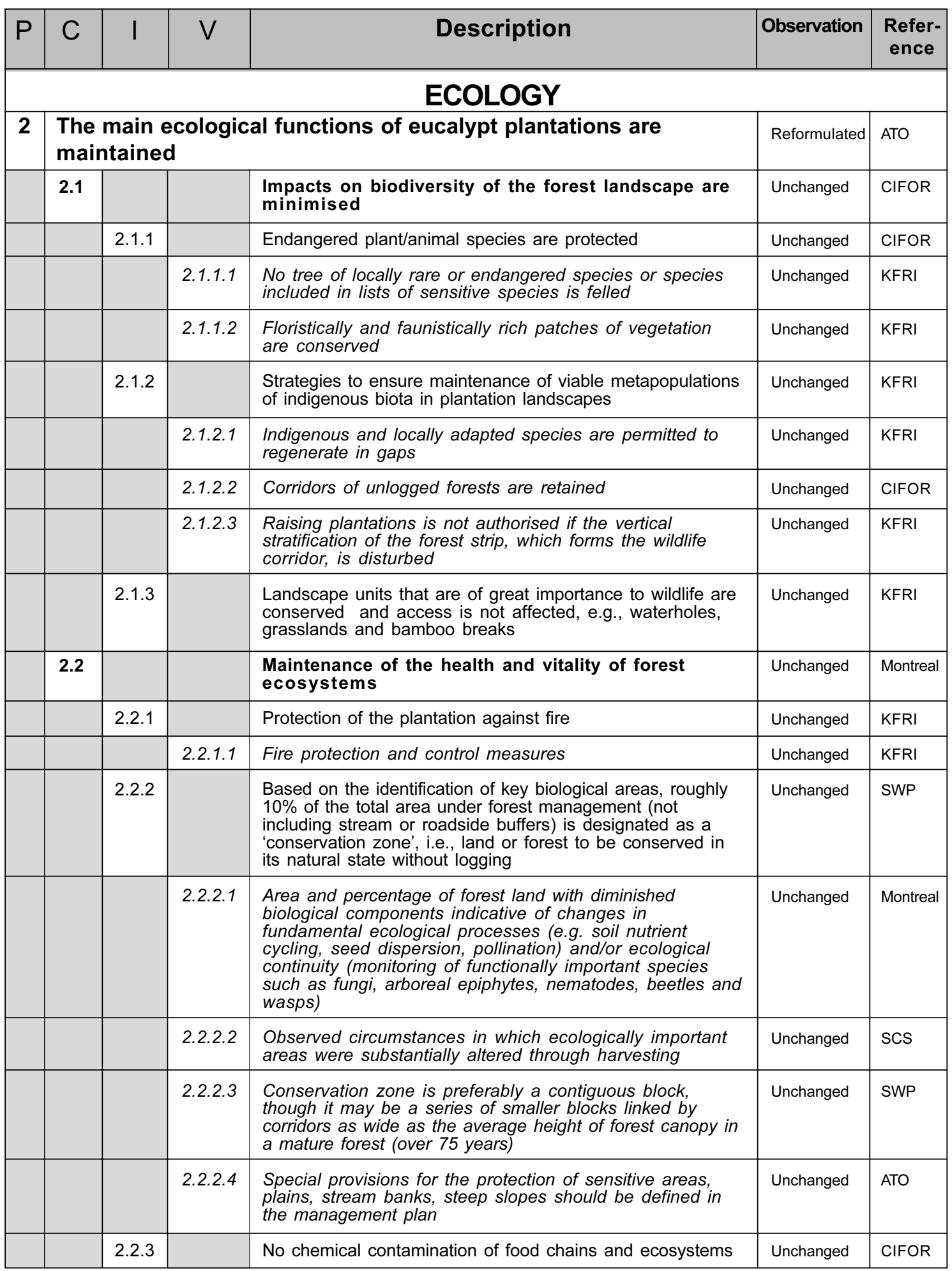


Annex 3.2 Continued

\begin{tabular}{|c|c|c|c|c|c|c|}
\hline $\mathrm{P}$ & $\mathrm{C}$ & I & V & Description & Observation & $\begin{array}{l}\text { Refer- } \\
\text { ence }\end{array}$ \\
\hline & & & 2.2.3.1 & $\begin{array}{l}\text { Policies and procedures for proper use and disposal of } \\
\text { hazardous materials }\end{array}$ & Unchanged & SCS \\
\hline & & & 2.2.3.2 & $\begin{array}{l}\text { Extent to which sivicultural methods minimise the need for } \\
\text { pesticides (avoidance of clear cutting and other measures } \\
\text { designed to limit hardwood incursion) }\end{array}$ & Unchanged & SCS \\
\hline & & & 2.2.3.3 & Frequency of pesticide use and stated reasons for use & Unchanged & Scs \\
\hline & & & 2.2.3.4 & $\begin{array}{l}\text { Chemicals banned in Europe, America or the target } \\
\text { country are not used }\end{array}$ & Unchanged & $\begin{array}{l}\text { Indo- } \\
\text { nesia }\end{array}$ \\
\hline & & & 2.2.3.5 & $\begin{array}{l}\text { Area and percentage of forest land experiencing an } \\
\text { accumulation of persistent toxic substances }\end{array}$ & Unchanged & Montreal \\
\hline & & & 2.2.3.6 & An integrated pest, disease and weed management plan & Unchanged & KFRI \\
\hline & & 2.2 .4 & & $\begin{array}{l}\text { Regulations for the introduction of single provenances/ } \\
\text { clones }\end{array}$ & Unchanged & KFRI \\
\hline & & & 2.2.4.1 & Use of only clones and provenances & Unchanged & SWP \\
\hline & & & 2.2.4.2 & $\begin{array}{l}\text { Use of provenances well adapted to the site, having high } \\
\text { degree of disease, drought resistance }\end{array}$ & Unchanged & KFRI \\
\hline & & 2.2 .5 & & $\begin{array}{l}\text { Minimisation of impacts of monocultures through mixed } \\
\text { cropping }\end{array}$ & Unchanged & KFRI \\
\hline & 2.3 & & & $\begin{array}{l}\text { Productive capacity of the land is maintained or } \\
\text { improved }\end{array}$ & Reformulated & Montreal \\
\hline & & 2.3 .1 & & $\begin{array}{l}\text { Measures for conserving or improving stability of } \\
\text { ecologically fragile localities are implemented }\end{array}$ & Unchanged & KFRI \\
\hline & & & 2.3.1.1 & $\begin{array}{l}\text { Plantations prohibited on slopes of over } 30^{\circ} \text { measured } \\
\text { over a terrestrial distance of } 100 \mathrm{~m}\end{array}$ & Unchanged & KFRI \\
\hline & & & 2.3.1.2 & $\begin{array}{l}\text { Ecologically sensitive areas, especially buffer zones along } \\
\text { watercourses, are protected }\end{array}$ & Unchanged & CIFOR \\
\hline & & & 2.3.1.3 & $\begin{array}{l}\text { Shelter belts of natural vegetation are retained on the } \\
\text { ridges }\end{array}$ & Unchanged & KFRI \\
\hline & & 2.3 .2 & & Watershed services of the land are maintained or enhanced & Unchanged & KFRI \\
\hline & & & 2.3.2.1 & Water infiltration rate & Unchanged & KFRI \\
\hline & & 2.3 .3 & & Decline in water quality in watershed or sub-watershed & Unchanged & $\begin{array}{l}\text { Côte } \\
\text { d'Ivoire }\end{array}$ \\
\hline & & 2.3.4 & & Provision for protection of bodies of water & Unchanged & KFRI \\
\hline & & & 2.3.4.1 & $\begin{array}{l}\text { Percentage of stream kilometers in forested catchment in } \\
\text { which stream flow and timing has significantly deviated } \\
\text { from the historical range of variation }\end{array}$ & Unchanged & Montreal \\
\hline & & 2.3 .5 & & Water system (regime) and quality do not decrease & Unchanged & ATO \\
\hline & & & 2.3.5.1 & $\begin{array}{l}\text { Percentage of water bodies in forest areas (e.g., stream } \\
\text { kilometres, lake hectares) with significant variance of } \\
\text { biological diversity from the historical range of variability }\end{array}$ & Unchanged & Montreal \\
\hline & & & 2.3.5.2 & $\begin{array}{l}\text { Percentage of water bodies in forest areas (e.g., stream } \\
\text { kilometres, lake hectares) with significant variation from } \\
\text { the historical range of variability in pH, dissolved oxygen, } \\
\text { levels of chemicals (electrical conductivity), sedimentation } \\
\text { or temperature change }\end{array}$ & Unchanged & Montreal \\
\hline & & & 2.3.5.3 & Run-off regime is not altered & Unchanged & KFRI \\
\hline
\end{tabular}




\section{Annex 3.2 Continued}

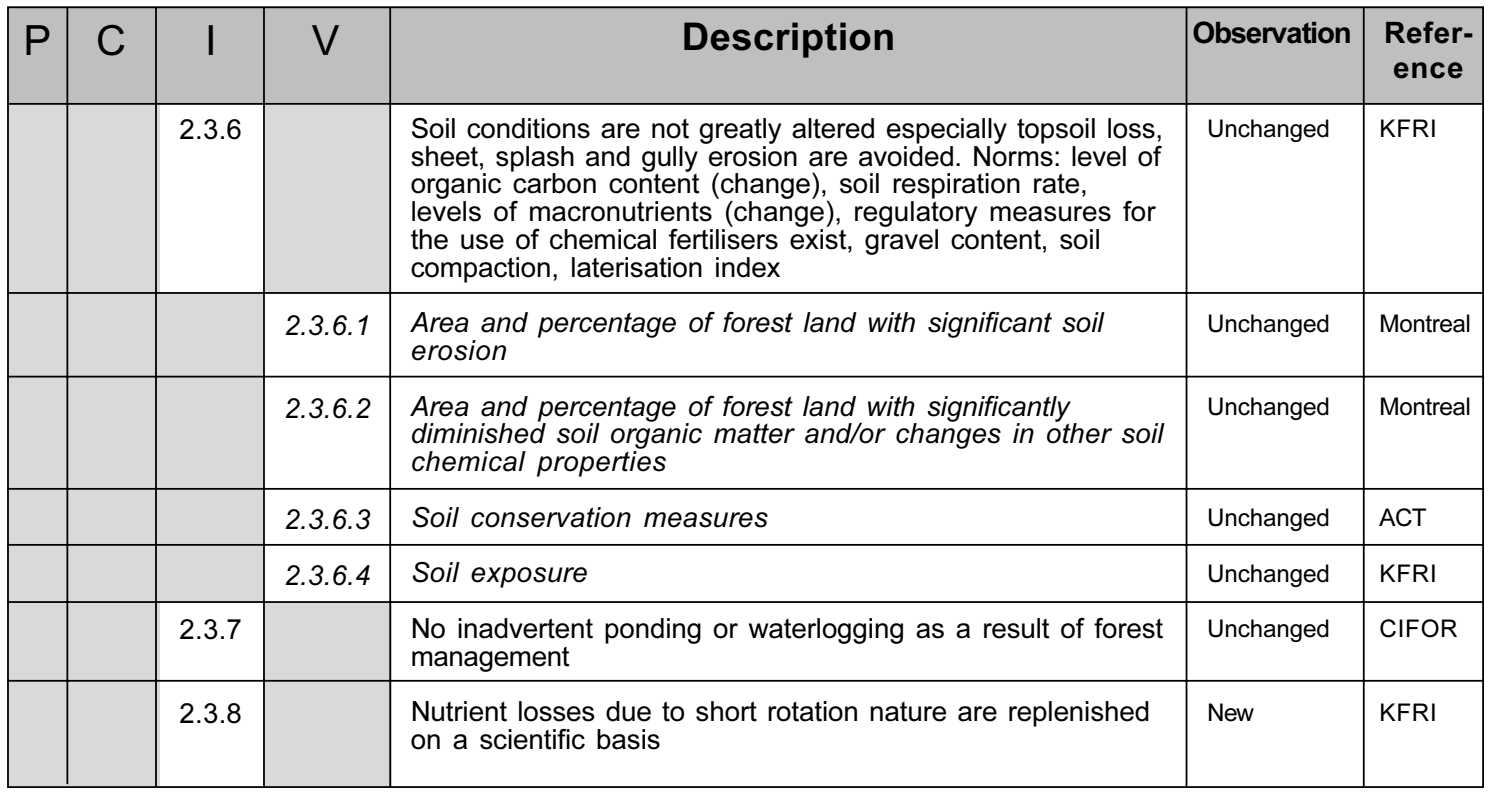


Annex 3.2 Continued

\begin{tabular}{|c|c|c|c|c|c|c|}
\hline $\mathrm{P}$ & C & I & V & Description & Observation & $\begin{array}{l}\text { Refer- } \\
\text { ence }\end{array}$ \\
\hline \multicolumn{7}{|c|}{ SOCIAL } \\
\hline \multirow[t]{2}{*}{3} & \multicolumn{4}{|c|}{$\begin{array}{l}\text { Plantation establishment and management maintains or } \\
\text { enhances intergenerational access to resources, economic } \\
\text { benefits and infrastructural facilities for local people and other } \\
\text { plantation labourers }\end{array}$} & Reformulated & CIFOR \\
\hline & 3.1 & & & $\begin{array}{l}\text { Local people accrue direct or indirect benefits from } \\
\text { the plantation activities }\end{array}$ & Unchanged & KFRI \\
\hline & & 3.1 .1 & & $\begin{array}{l}\text { Local people, both men and women, get employment and } \\
\text { promotion opportunities }\end{array}$ & Reformulated & CIFOR \\
\hline & & & 3.1 .1 .1 & Proportion of local employees & Unchanged & KFRI \\
\hline & & & 3.1 .1 .2 & Reservation policies for locals exist and are followed & Unchanged & KFRI \\
\hline & & & 3.1.1.3 & $\begin{array}{l}\text { Proportion of/representation of officers in management } \\
\text { level }\end{array}$ & Unchanged & KFRI \\
\hline & & 3.1 .2 & & Local people are given training (job-oriented) & Reformulated & SA \\
\hline & & & 3.1.2.1 & $\begin{array}{l}\text { There is a regular locally relevant training programme or } \\
\text { skill development for locals run by FMU }\end{array}$ & Unchanged & KFRI \\
\hline & & & 3.1.2.2 & The training programme is beneficial for locals & Unchanged & KFRI \\
\hline & & 3.1 .3 & & $\begin{array}{l}\text { Schools and educational facilities for local and other } \\
\text { employees }\end{array}$ & Reformulated & SA \\
\hline & & & 3.1.3.1 & Nature awareness pogrammes & Unchanged & KFRI \\
\hline & & & 3.1.3.2 & Student-teacher ratio & Unchanged & KFRI \\
\hline & & & 3.1 .3 .3 & Scholarships & Unchanged & KFRI \\
\hline & & 3.1 .4 & & $\begin{array}{l}\text { Local and indigenous people are given preference in } \\
\text { competitive bidding and are encouraged to take up contract } \\
\text { activities }\end{array}$ & Unchanged & KFRI \\
\hline & & & 3.1 .4 .1 & $\begin{array}{l}\text { Policy exists to give preference for locals in plantation } \\
\text { bidding }\end{array}$ & Unchanged & KFRI \\
\hline & & & 3.1 .4 .2 & Contractors are encouraged to employ locals & Unchanged & KFRI \\
\hline & & 3.1 .5 & & $\begin{array}{l}\text { Supply of fuel for employees and locals under collective } \\
\text { management programmes }\end{array}$ & Unchanged & KFRI \\
\hline & & & 3.1 .5 .1 & Cooking fuel & Unchanged & KFRI \\
\hline & & 3.1 .6 & & $\begin{array}{l}\text { Water conservation/water distribution facilities equally } \\
\text { benefit employees and local people either at a concessional } \\
\text { rate or free of cost }\end{array}$ & Unchanged & KFRI \\
\hline & & & 3.1 .6 .1 & $\begin{array}{l}\text { There is a soil and water conservation programme } \\
\text { implemented by the FMU }\end{array}$ & Unchanged & KFRI \\
\hline & & & 3.1 .6 .2 & $\begin{array}{l}\text { Local people are educated on cost-effective and low-cost } \\
\text { soil and water conservation programmes }\end{array}$ & Unchanged & KFRI \\
\hline & & 3.1 .7 & & $\begin{array}{l}\text { Road and other communication systems are accessible to } \\
\text { local people as well }\end{array}$ & Unchanged & KFRI \\
\hline & & 3.1 .8 & & $\begin{array}{l}\text { Local food security is not affected because of plantation } \\
\text { extension }\end{array}$ & Unchanged & KFRI \\
\hline
\end{tabular}


Annex 3.2 Continued

\begin{tabular}{|c|c|c|c|c|c|c|}
\hline$P$ & $\mathrm{C}$ & I & V & Description & Observation & $\begin{array}{l}\text { Refer- } \\
\text { ence }\end{array}$ \\
\hline & & & 3.1.8.1 & $\begin{array}{l}\text { Changes in cropping pattern to commercial crops following } \\
\text { plantation activities }\end{array}$ & Unchanged & KFRI \\
\hline & 3.2 & & & $\begin{array}{l}\text { Traditional livelihood security or income-generating } \\
\text { opportunities for people are not negatively affected }\end{array}$ & Unchanged & KFRI \\
\hline & & 3.2 .1 & & $\begin{array}{l}\text { Tribal people are adequately compensated or alternatives } \\
\text { are provided }\end{array}$ & Unchanged & KFRI \\
\hline & & & 3.2.1.1 & Details of resettlement & Unchanged & KFRI \\
\hline & & 3.2 .2 & & NWFP collection from the forest is not affected & Unchanged & KFRI \\
\hline & 3.3 & & & $\begin{array}{l}\text { Labourers and employees are compensated } \\
\text { adequately and their rights are protected }\end{array}$ & Reformulated & SWP \\
\hline & & 3.3 .1 & & Periodic revision of employees' compensation occurs & Reformulated & SWP \\
\hline & & & 3.3.1.1 & Incidents of protests & Unchanged & KFRI \\
\hline & & 3.3 .2 & & Compliance with international or national labour rules & Reformulated & SA \\
\hline & & & 3.3.2.1 & Welfare schemes & Unchanged & KFRI \\
\hline & 3.4 & & & Tenure rights of the local people are secure & Reformulated & CIFOR \\
\hline & & 3.4 .1 & & $\begin{array}{l}\text { No incident of bullying and threats from plantation } \\
\text { authorities }\end{array}$ & Unchanged & KFRI \\
\hline & & & 3.4.1.1 & Cases, rumours, etc. & Unchanged & KFRI \\
\hline & 3.5 & & & $\begin{array}{l}\text { Indirect benefits from tourism activities do not have } \\
\text { any hidden social cost involved }\end{array}$ & Unchanged & KFRI \\
\hline & & 3.5 .1 & & $\begin{array}{l}\text { Tourism activities associated with plantations do not affect } \\
\text { the local resource equity, and do not result in displacement } \\
\text { or marginalisation of local or indigenous populations }\end{array}$ & Unchanged & KFRI \\
\hline & & & 3.5.1.1 & Rise in land value & Unchanged & KFRI \\
\hline & & & 3.5.1.2 & Change in land use to urban & Unchanged & KFRI \\
\hline & & & 3.5.1.3 & $\begin{array}{l}\text { Privatisation of common water bodies, playing grounds or } \\
\text { pastoral lands }\end{array}$ & Unchanged & KFRI \\
\hline & & 3.5 .2 & & $\begin{array}{l}\text { Plantation activities or other recreation facilities are not } \\
\text { gender discriminatory at the local level }\end{array}$ & Unchanged & KFRI \\
\hline & & & 3.5.2.1 & Number of minor cases & Unchanged & KFRI \\
\hline \multirow[t]{5}{*}{4} & \multicolumn{4}{|c|}{$\begin{array}{l}\text { Stakeholders, including locals and forest actors, have a voice in } \\
\text { plantation management }\end{array}$} & Reformulated & CIFOR \\
\hline & 4.1 & & & $\begin{array}{l}\text { Plantation management involves local people in } \\
\text { areas of common interest }\end{array}$ & Unchanged & KFRI \\
\hline & & 4.1 .1 & & Efficient maintenance of common wood lots & Reformulated & SWP \\
\hline & & 4.1 .2 & & Participation in fire protection & Reformulated & SA \\
\hline & & 4.1 .3 & & Participation in watershed development programmes & Unchanged & KFRI \\
\hline
\end{tabular}


Annex 3.2 Continued

\begin{tabular}{|c|c|c|c|c|c|c|}
\hline $\mathrm{P}$ & C & I & V & Description & Observation & $\begin{array}{l}\text { Refer- } \\
\text { ence }\end{array}$ \\
\hline \multicolumn{7}{|c|}{ MANAGEMENT } \\
\hline \multirow[t]{2}{*}{5} & \multicolumn{4}{|c|}{$\begin{array}{l}\text { Eucalypt plantation management encourages an optimal and } \\
\text { efficient use of products and services in order to ensure } \\
\text { sustainable yield and quality }\end{array}$} & & \\
\hline & 5.1 & & & $\begin{array}{l}\text { Management objectives are clearly and precisely } \\
\text { described and documented }\end{array}$ & Reformulated & FSC \\
\hline & & 5.1 .1 & & $\begin{array}{l}\text { Objectives are clearly stated in terms of major functions of } \\
\text { the plantation }\end{array}$ & Reformulated & SA \\
\hline & 5.2 & & & $\begin{array}{l}\text { A comprehensive management plan exists, which } \\
\text { ensures the economic and ecological sustainablility } \\
\text { of the eucalypt plantation }\end{array}$ & Unchanged & KFRI \\
\hline & & 5.2 .1 & & A management plan is available & Unchanged & CIFOR \\
\hline & & 5.2 .2 & & Yield management plans ensure economic viability & Unchanged & KFRI \\
\hline & & & 5.2.2.1 & Yield regulation by area and/or volume prescribed & Unchanged & CIFOR \\
\hline & & & 5.2.2.2 & $\begin{array}{l}\text { The number of trees and/or volume of timber per hectare } \\
\text { harvested }\end{array}$ & Unchanged & KFRI \\
\hline & & 5.2 .3 & & Marketing strategies avoid gluts in the market & Unchanged & KFRI \\
\hline & & & 5.2 .3 .1 & $\begin{array}{l}\text { Marketing strategies and the extent to which products are } \\
\text { marketed for their highest-value uses }\end{array}$ & Unchanged & KFRI \\
\hline & & 5.2 .4 & & $\begin{array}{l}\text { Management plans to prevent natural catastrophes (e.g., } \\
\text { fires) and planning responses for resources stabilisation } \\
\text { and recovery }\end{array}$ & Reformulated & ACT \\
\hline & & 5.2 .5 & & Harvest regulation plans minimise environmental impacts & Unchanged & KFRI \\
\hline & & & 5.2.5.1 & The presence of clear, official harvesting rules & Unchanged & ITTO \\
\hline & & & 5.2 .5 .2 & $\begin{array}{l}\text { Harvesting systems and equipment are prescribed to } \\
\text { match forest conditions in order to reduce impact }\end{array}$ & Reformulated & SA \\
\hline & 5.3 & & & The management plan is effectively implemented & Reformulated & ATO \\
\hline & & 5.3 .1 & & $\begin{array}{l}\text { Harvest efficiency and product utilisation ensures economic } \\
\text { sustainability }\end{array}$ & Reformulated & scs \\
\hline & & & 5.3.1.1 & Production statistics of timber over time & Reformulated & ITTO \\
\hline & & & 5.3.1.2 & $\begin{array}{l}\text { The efficiency and economic viability of marketing of forest } \\
\text { products locally, regionally and internationally }\end{array}$ & Unchanged & KFRI \\
\hline & & & 5.3.1.3 & $\begin{array}{l}\text { Review of company's annual financial statements, which } \\
\text { provide information such as annual return on investment } \\
\text { rates }\end{array}$ & Unchanged & KFRI \\
\hline & & & 5.3.1.4 & Actual yield per hectare as compared to predicted yield & Unchanged & KFRI \\
\hline & & 5.3 .2 & & Reduced-impact felling specified/implemented & Reformulated & ATO \\
\hline & & & 5.3.2.1 & Low-impact felling techniques are available & Reformulated & ATO \\
\hline & & & 5.3.2.2 & $\begin{array}{l}\text { Frequency of excessive felling damage to harvested trees } \\
\text { and extent of 'skinned' residual trees or trees with tops } \\
\text { broken during harvesting operations }\end{array}$ & Reformulated & Scs \\
\hline & & & 5.3 .2 .3 & $\begin{array}{l}\text { Directional felling techniques are being used (i.e. trees } \\
\text { are felled parallel to or in the direction of skidding) }\end{array}$ & Reformulated & SA \\
\hline
\end{tabular}


Annex 3.2 Continued

\begin{tabular}{|c|c|c|c|c|c|c|}
\hline $\mathrm{P}$ & C & I & V & Description & Observation & $\begin{array}{l}\text { Refer- } \\
\text { ence }\end{array}$ \\
\hline & & 5.3 .3 & & $\begin{array}{l}\text { Sustainable timber production (in quality and quantity) is } \\
\text { guaranteed }\end{array}$ & Unchanged & KFRI \\
\hline & & & 5.3.3.1 & $\begin{array}{l}\text { Silvicultural prescriptions (pre, during, and post-harvest) } \\
\text { are being adhered to }\end{array}$ & Unchanged & KFRI \\
\hline & & & 5.3.3.2 & $\begin{array}{l}\text { Growth rates, stocking and regeneration are being } \\
\text { monitored by a suitable continuous forest inventory system }\end{array}$ & Reformulated & FSC \\
\hline & & & 5.3.3.3 & $\begin{array}{l}\text { Extent to which expedient prescriptions such as diameter- } \\
\text { limit harvesting are routinely applied }\end{array}$ & Unchanged & KFRI \\
\hline & & & 5.3.3.4 & Harvest trees are marked prior to logging & Reformulated & ITTO \\
\hline & & & 5.3.3.5 & A pre-logging stand inventory & Unchanged & ITTO \\
\hline & & 5.3 .4 & & Skidding damage to trees and soil is minimised & Unchanged & CIFOR \\
\hline & & & 5.3.4.1 & $\begin{array}{l}\text { Front end of logs is lifted off ground during mechanical } \\
\text { skidding }\end{array}$ & Unchanged & SWP \\
\hline & & & 5.3.4.2 & Skid trail gradients do not exceed 25 degrees & Unchanged & SWP \\
\hline & & & 5.3.4.3 & $\begin{array}{l}\text { Specifications in terms of skid trail width and location have } \\
\text { been set and are being followed }\end{array}$ & Unchanged & SWP \\
\hline & & 5.3 .5 & & $\begin{array}{l}\text { Forest management minimises impacts of logging on } \\
\text { plantation's structure and biodiversity }\end{array}$ & Unchanged & KFRI \\
\hline & & & 5.3.5.1 & Canopy opening is minimised & Unchanged & CIFOR \\
\hline & 5.4 & & & $\begin{array}{l}\text { An efficient monitoring and control system is } \\
\text { present to periodically revise management } \\
\text { prescriptions based on new information }\end{array}$ & Reformulated & FSC \\
\hline & & 5.4 .1 & & $\begin{array}{l}\text { Documentation and records of all management activities are } \\
\text { kept in a form that makes it possible for monitoring to occur }\end{array}$ & Unchanged & CIFOR \\
\hline & & 5.4 .2 & & $\begin{array}{l}\text { Monitoring procedures for acquiring information on plan } \\
\text { attainment and resource conditions }\end{array}$ & Unchanged & KFRI \\
\hline & & & 5.4.2.1 & Records of annual areas cut over time & Reformulated & SWP \\
\hline & & & 5.4.2.2 & $\begin{array}{l}\text { Actual annual harvest levels as compared to planned } \\
\text { levels }\end{array}$ & Unchanged & KFRI \\
\hline & & & 5.4.2.3 & $\begin{array}{l}\text { Provision for monitoring the residual growing stock after } \\
\text { logging }\end{array}$ & Unchanged & KFRI \\
\hline
\end{tabular}


Annex 3.3 Criteria and indicators of sustainable management for teak plantations of Madhya Pradesh selected after field testing by Team 3.

\begin{tabular}{|c|c|c|c|c|c|c|}
\hline $\mathrm{P}$ & C & I & V & Description & Observation & $\begin{array}{l}\text { Refer- } \\
\text { ence }\end{array}$ \\
\hline \multirow[t]{2}{*}{1} & \multicolumn{4}{|c|}{$\begin{array}{l}\text { Planning and institutional frameworks are conducive for } \\
\text { sustainable management of forest plantations }\end{array}$} & Reformulated & CIFOR \\
\hline & 1.1 & & & $\begin{array}{l}\text { There exists policy and legal frameworks for } \\
\text { plantation land use }\end{array}$ & New & $\begin{array}{l}\text { BIP/ } \\
\text { KFRI }\end{array}$ \\
\hline & 1.2 & & & $\begin{array}{l}\text { There exists adequate and trained manpower in } \\
\text { plantation forestry }\end{array}$ & New & $\begin{array}{l}\text { BIPI } \\
\text { KFRI }\end{array}$ \\
\hline & & 1.2 .1 & & Periodicity of the training programmes & New & $\begin{array}{l}\text { BIPI } \\
\text { KFRI } \\
\end{array}$ \\
\hline & & 1.2 .2 & & Content of the training programme is relevant & New & $\begin{array}{l}\text { BIPI } \\
\text { KFRI }\end{array}$ \\
\hline & 1.3 & & & $\begin{array}{l}\text { Information for forest resource accounting, } \\
\text { including that of plantation forests, is available on a } \\
\text { periodic basis }\end{array}$ & New & $\begin{array}{l}\text { BIPI } \\
\text { KFRI }\end{array}$ \\
\hline & & 1.3 .1 & & Management plans are user-friendly & New & $\begin{array}{l}\text { BIPI } \\
\text { KFRI }\end{array}$ \\
\hline & & & 1.3.1.1 & Management plans are also available in the local language & New & $\begin{array}{l}\text { BIPI } \\
\text { KFRI }\end{array}$ \\
\hline & 1.4 & & & $\begin{array}{l}\text { Monitoring and evaluation of the plantation projects } \\
\text { and forest resource accounting are carried out } \\
\text { periodically }\end{array}$ & New & $\begin{array}{l}\text { BIPI } \\
\text { KFRI }\end{array}$ \\
\hline & 1.5 & & & $\begin{array}{l}\text { Reinvestment policies are conducive to sustainable } \\
\text { plantation management }\end{array}$ & New & $\begin{array}{l}\text { BIPI } \\
\text { KFRI }\end{array}$ \\
\hline & 1.6 & & & $\begin{array}{l}\text { Policy and legislation encourage and efficiently } \\
\text { regulate the plantation forestry business in the } \\
\text { private sector }\end{array}$ & Unchanged & KFRI \\
\hline & & 1.6 .1 & & $\begin{array}{l}\text { Land conversion, type of land and change in cropping } \\
\text { pattern are recorded }\end{array}$ & New & $\begin{array}{l}\text { BIPI } \\
\text { KFRI }\end{array}$ \\
\hline & & 1.6 .2 & & Production targets, markets and financial goals are stated & New & $\begin{array}{l}\text { BIPI } \\
\text { KFRI }\end{array}$ \\
\hline & & 1.6 .3 & & Product quality is monitored & New & $\begin{array}{l}\text { BIPI } \\
\text { KFRI }\end{array}$ \\
\hline & & 1.6 .4 & & $\begin{array}{l}\text { There is provision for government intervention in existing } \\
\text { rules, taxation policies and the regulatory environment }\end{array}$ & New & $\begin{array}{l}\text { BIPI } \\
\text { KFRI }\end{array}$ \\
\hline
\end{tabular}


Annex 3.3 Continued

\begin{tabular}{|c|c|c|c|c|c|c|}
\hline $\mathrm{P}$ & $\mathrm{C}$ & I & V & Description & Observation & $\begin{array}{l}\text { Refer- } \\
\text { ence }\end{array}$ \\
\hline \multirow[t]{2}{*}{2} & \multicolumn{4}{|c|}{$\begin{array}{l}\text { Ecological structure, function and processes of the forests are } \\
\text { maintained }\end{array}$} & Reformulated & ATO \\
\hline & 2.1 & & & $\begin{array}{l}\text { Areas under natural forests, plantations are } \\
\text { maintained or improved }\end{array}$ & New & $\begin{array}{l}\text { BIPI } \\
\text { KFRI }\end{array}$ \\
\hline & & 2.1 .1 & & $\begin{array}{l}\text { In a given FMU the percentage of plantations does not } \\
\text { exceed more than } 50 \% \text { of the forest land area }\end{array}$ & New & $\begin{array}{l}\text { BIP/ } \\
\text { KFRI }\end{array}$ \\
\hline & 2.2 & & & $\begin{array}{l}\text { Maintenance of health and vitality of teak plantation } \\
\text { ecosystem }\end{array}$ & Unchanged & Montreal \\
\hline & & 2.2 .1 & & Protection of the plantation against fire, pests and diseases & New & $\begin{array}{l}\text { BIPI } \\
\text { KFRI }\end{array}$ \\
\hline & & & 2.2.1.1 & Fire protection and control measures implemented on time & Reformulated & KFRI \\
\hline & & & 2.2.1.2 & Frequency of fire & New & $\begin{array}{l}\text { BIPI } \\
\text { KFRI }\end{array}$ \\
\hline & & & 2.2.1.3 & Area affected & New & $\begin{array}{l}\text { BIPI } \\
\text { KFRI }\end{array}$ \\
\hline & & 2.2 .2 & & No chemical contamination of food chains and ecosystems & Unchanged & CIFOR \\
\hline & & & 2.2.2.1 & $\begin{array}{l}\text { Integrated pest, disease and weed management strategies } \\
\text { adopted }\end{array}$ & Reformulated & KFRI \\
\hline & & & 2.2 .2 .2 & $\begin{array}{l}\text { Chemical application should conform to existing } \\
\text { legislation }\end{array}$ & Unchanged & $\begin{array}{l}\text { BIP/ } \\
\text { KFRI }\end{array}$ \\
\hline & & 2.2 .3 & & Genetic diversity is maintained & Unchanged & $\begin{array}{l}\text { BIPI } \\
\text { KFRI }\end{array}$ \\
\hline & & & 2.2.3.1 & $\begin{array}{l}\text { Use of provenance well adapted to the site, having high } \\
\text { degree of resistance to disease and drought }\end{array}$ & Unchanged & KFRI \\
\hline & & & 2.2.3.2 & $\begin{array}{l}\text { Use of certified and quality planting material of known } \\
\text { origin }\end{array}$ & New & $\begin{array}{l}\text { BIP/ } \\
\text { KFRI }\end{array}$ \\
\hline & 2.3 & & & $\begin{array}{l}\text { Productive capacity of the site is maintained or } \\
\text { improved }\end{array}$ & New & $\begin{array}{l}\text { BIP/ } \\
\text { KFRI }\end{array}$ \\
\hline & & 2.3 .1 & & $\begin{array}{l}\text { Optimal stocking (as per the management plan) so as to } \\
\text { minimise canopy opening }\end{array}$ & Reformulated & CIFOR \\
\hline & & 2.3 .2 & & $\begin{array}{l}\text { Measures for conserving or improving stability of } \\
\text { ecologically fragile localities are implemented }\end{array}$ & Unchanged & KFRI \\
\hline & & & 2.3.2.1 & $\begin{array}{l}\text { Ecologically sensitive areas, especially buffer zones along } \\
\text { watercourses, are protected }\end{array}$ & Unchanged & CIFOR \\
\hline & & 2.3 .3 & & Productive capacity of the soil is maintained or improved & Reformulated & Montreal \\
\hline & & & 2.3.3.1 & Area under soil compaction & Unchanged & Montreal \\
\hline & & & 2.3.3.2 & Percentage of area under poding & Unchanged & Montreal \\
\hline & & & 2.3.3.3 & Percentage of area under waterlogging & Unchanged & Montreal \\
\hline & & & 2.3.3.4 & Degree of soil erosion & Unchanged & Montreal \\
\hline & & & 2.3.3.5 & $\begin{array}{l}\text { Area and percentage of forest land with significantly } \\
\text { diminished soil organic matter in terms of depth of the } \\
\text { humus layer }\end{array}$ & New & $\begin{array}{l}\text { BIP/ } \\
\text { KFRI }\end{array}$ \\
\hline
\end{tabular}


Annex 3.3 Continued

\begin{tabular}{|c|c|c|c|c|c|c|}
\hline $\mathrm{P}$ & $\mathrm{C}$ & I & V & Description & Observation & $\begin{array}{l}\text { Refer- } \\
\text { ence }\end{array}$ \\
\hline & & & 2.3.3.6 & Soil conservation measures properly implemented & Reformulated & KFRI \\
\hline & & & 2.3.3.7 & $\begin{array}{l}\text { Soil exposure (canopy cover, stocking, fire, removal of } \\
\text { litter) }\end{array}$ & Reformulated & KFRI \\
\hline & 2.4 & & & $\begin{array}{l}\text { Adverse impact on biodiversity of the forest } \\
\text { landscape is minimised }\end{array}$ & Reformulated & CIFOR \\
\hline & & 2.4 .1 & & Endangered plant/animal species are protected & Unchanged & CIFOR \\
\hline & & & 2.4.1.1 & $\begin{array}{l}\text { Trees of locally rare or endangered species or socially } \\
\text { important species are not felled }\end{array}$ & Reformulated & $\begin{array}{l}\text { Côte } \\
\text { d'Ivoire }\end{array}$ \\
\hline & & & 2.4.1.2 & $\begin{array}{l}\text { Floristically and faunistically rich patches of vegetation are } \\
\text { conserved }\end{array}$ & Unchanged & KFRI \\
\hline & & 2.4 .2 & & $\begin{array}{l}\text { Strategies to ensure maintenance of viable wildlife (flora } \\
\text { and fauna) populations in the plantation landscapes }\end{array}$ & Reformulated & KFRI \\
\hline & & & 2.4.2.1 & Corridors of unlogged forests are retained (if necessary) & Reformulated & CIFOR \\
\hline & & & 2.4.2.2 & $\begin{array}{l}\text { Raising plantations is not authorised if the vertical } \\
\text { stratification of the forest strip, which forms the wildlife } \\
\text { corridor, is disturbed }\end{array}$ & Unchanged & KFRI \\
\hline & & & 2.4.2.3 & $\begin{array}{l}\text { Landscape units that are of great importance to wildlife are } \\
\text { conserved and are accessible to wildlife, e.g., waterholes, } \\
\text { grasslands and bamboo breaks }\end{array}$ & Reformulated & KFRI \\
\hline & 2.5 & & & $\begin{array}{l}\text { Watershed functions of the land are maintained or } \\
\text { enhanced }\end{array}$ & Reformulated & KFRI \\
\hline & & 2.5 .1 & & Water quality is maintained or enhanced & Reformulated & ATO \\
\hline & & & 2.5.1.1 & $\begin{array}{l}\text { Water quality is maintained within the range of seasonal } \\
\text { variations }\end{array}$ & New & $\begin{array}{l}\text { BIPI } \\
\text { KFRI }\end{array}$ \\
\hline
\end{tabular}


Annex 3.3 Continued

\begin{tabular}{|c|c|c|c|c|c|c|}
\hline $\mathrm{P}$ & C & I & V & Description & Observation & $\begin{array}{l}\text { Refer- } \\
\text { ence }\end{array}$ \\
\hline \multicolumn{7}{|c|}{ SOCIAL } \\
\hline \multirow[t]{2}{*}{3} & \multicolumn{4}{|c|}{ Socio-economic benefits are maintained or enhanced } & New & $\begin{array}{l}\text { BIP/ } \\
\text { KFRI }\end{array}$ \\
\hline & 3.1 & & & $\begin{array}{l}\text { Local people accrue benefits from the plantation } \\
\text { activities }\end{array}$ & Reformulated & KFRI \\
\hline & & 3.1 .1 & & $\begin{array}{l}\text { Local people, both men and women, get employment and } \\
\text { promotion opportunities }\end{array}$ & Reformulated & KFRI \\
\hline & & & 3.1.1.1 & Proportion of local employees & Unchanged & KFRI \\
\hline & & & 3.1.1.2 & Equity in employment & Unchanged & KFRI \\
\hline & & 3.1 .2 & & $\begin{array}{l}\text { Educational facilities, if run by the plantation management, } \\
\text { are made available to the locals also }\end{array}$ & Unchanged & KFRI \\
\hline & & & 3.1.2.1 & Local people are given vocational training & Reformulated & KFRI \\
\hline & & & 3.1.2.2 & $\begin{array}{l}\text { There is a regular locally relevant training programme or } \\
\text { skill development for locals run by the FMU }\end{array}$ & Unchanged & KFRI \\
\hline & & & 3.1 .2 .3 & The training programme is beneficial for locals & Unchanged & KFRI \\
\hline & & & 3.1.2.4 & Nature awareness programmes & Unchanged & KFRI \\
\hline & & & 3.1.2.5 & Student-teacher ratio & Unchanged & KFRI \\
\hline & & & 3.1.2.6 & Scholarships & Unchanged & KFRI \\
\hline & & 3.1 .3 & & $\begin{array}{l}\text { Supply of fuel for employees and locals under collective } \\
\text { management programmes }\end{array}$ & Unchanged & KFRI \\
\hline & & & 3.1.3.1 & $\begin{array}{l}\text { Availability of wood fuel, fodder, thatching and construction } \\
\text { material }\end{array}$ & Unchanged & $\begin{array}{l}\text { BIPI } \\
\text { KFRI }\end{array}$ \\
\hline & & 3.1 .4 & & $\begin{array}{l}\text { Drinking water facilities equally benefit employees and local } \\
\text { people }\end{array}$ & Reformulated & KFRI \\
\hline & & & 3.1 .4 .1 & $\begin{array}{l}\text { Communities have access to adequate and good quality } \\
\text { water }\end{array}$ & New & $\begin{array}{l}\text { BIPI } \\
\text { KFRI }\end{array}$ \\
\hline & & 3.1 .5 & & $\begin{array}{l}\text { Road and other communication systems are accessible to } \\
\text { local people as well }\end{array}$ & Unchanged & KFRI \\
\hline & & 3.1 .6 & & $\begin{array}{l}\text { Local food security is not affected because of plantation } \\
\text { extension }\end{array}$ & Unchanged & KFRI \\
\hline & & & 3.1 .6 .1 & $\begin{array}{l}\text { Changes in cropping pattern to commercial crops following } \\
\text { the plantation activities }\end{array}$ & Unchanged & KFRI \\
\hline & & & 3.1 .6 .2 & Agricultural lands are not coverted to plantation & New & $\begin{array}{l}\text { BIP/ } \\
\text { KFRI } \\
\end{array}$ \\
\hline & 3.2 & & & $\begin{array}{l}\text { Traditional livelihood security or income-generating } \\
\text { opportunities for people are not adversely affected }\end{array}$ & Reformulated & ACT \\
\hline & & 3.2 .1 & & $\begin{array}{l}\text { Forest-dependent people are adequately compensated or } \\
\text { alternatives are provided }\end{array}$ & New & $\begin{array}{l}\text { BIP/ } \\
\text { KFRI }\end{array}$ \\
\hline & & & 3.2.1.1 & Direct employment in the forestry sector & Reformulated & CIFOR \\
\hline & & 3.2 .2 & & NWFP collection from the forest is not affected & New & $\begin{array}{l}\text { BIPI } \\
\text { KFRI }\end{array}$ \\
\hline & 3.3 & & & $\begin{array}{l}\text { Labourers and employees are adequately } \\
\text { compensated and ther rights are protected }\end{array}$ & Reformulated & SWP \\
\hline
\end{tabular}


Annex 3.3 Continued

\begin{tabular}{|c|c|c|c|c|c|c|}
\hline $\mathrm{P}$ & C & I & V & Description & Observation & $\begin{array}{l}\text { Refer- } \\
\text { ence }\end{array}$ \\
\hline & & 3.3.1 & & Periodic wage revision occurs & New & $\begin{array}{l}\text { BIP/ } \\
\text { KFRI }\end{array}$ \\
\hline & & & 3.3.1.1 & Incidence of protests & Unchanged & KFRI \\
\hline & & & 3.3.1.2 & Wage revision reports & New & $\begin{array}{l}\text { BIPI } \\
\text { KFRI }\end{array}$ \\
\hline & & 3.3 .2 & & National labour rules are implemented & New & $\begin{array}{l}\text { BIPI } \\
\text { KFRI }\end{array}$ \\
\hline & & & 3.3.2.1 & Welfare schemes & Unchanged & KFRI \\
\hline & 3.4 & & & Tenure rights of the local people are secure & Reformulated & CIFOR \\
\hline & & 3.4 .1 & & $\begin{array}{l}\text { No incidents of bullying and threats from the plantation } \\
\text { authorities }\end{array}$ & Reformulated & KFRI \\
\hline & & & 3.4.1.1 & Cases, rumours, etc. & Unchanged & KFRI \\
\hline & 3.5 & & & $\begin{array}{l}\text { Indirect benefits from tourism activities do not have } \\
\text { any hidden social cost involved }\end{array}$ & Unchanged & KFRI \\
\hline & & 3.5 .1 & & $\begin{array}{l}\text { Tourism activities associated with plantations do not affect } \\
\text { the local resource equity, and do not result in displacement } \\
\text { or marginalisation of local or indigenous populations }\end{array}$ & Reformulated & KFRI \\
\hline & & & 3.5.1.1 & Rise in land value & Unchanged & KFRI \\
\hline & & & 3.5.1.2 & Change in land use from rural to urban & Reformulated & KFRI \\
\hline & & & 3.5.1.3 & $\begin{array}{l}\text { Privatisation of common water bodies, playing grounds or } \\
\text { pastoral lands for tourism development }\end{array}$ & Reformulated & KFRI \\
\hline & & 3.5 .2 & & $\begin{array}{l}\text { Plantation activities or other recreation facilities are not } \\
\text { gender discriminatory at the local level }\end{array}$ & Reformulated & KFRI \\
\hline & & & 3.5.2.1 & Number of minor cases & Unchanged & KFRI \\
\hline & 3.6 & & & $\begin{array}{l}\text { Plantation management involves local people in } \\
\text { areas of common interest }\end{array}$ & Unchanged & KFRI \\
\hline & & 3.6 .1 & & Efficient maintenance of common wood lots & Reformulated & SWP \\
\hline & & 3.6 .2 & & Participation in fire protection & Reformulated & SA \\
\hline & & 3.6 .3 & & Participation in watershed development programmes & Unchanged & KFRI \\
\hline & & 3.6 .4 & & Community participation in grazing control & New & $\begin{array}{l}\text { BIPI } \\
\text { KFRI }\end{array}$ \\
\hline
\end{tabular}


Annex 3.3 Continued

\begin{tabular}{|c|c|c|c|c|c|c|}
\hline $\mathrm{P}$ & C & I & V & Description & Observation & $\begin{array}{l}\text { Refer- } \\
\text { ence }\end{array}$ \\
\hline \multicolumn{7}{|c|}{ MANAGEMENT } \\
\hline \multirow[t]{2}{*}{4} & \multicolumn{4}{|c|}{ Yield and quality of forest products and resources are improved } & Reformulated & CIFOR \\
\hline & 4.1 & & & $\begin{array}{l}\text { Management objectives are clearly and precisely } \\
\text { described and documented }\end{array}$ & Reformulated & FSC \\
\hline & & 4.1.1 & & $\begin{array}{l}\text { Objectives are clearly stated in terms of major functions of } \\
\text { the plantation }\end{array}$ & Reformulated & SA \\
\hline & 4.2 & & & $\begin{array}{l}\text { A comprehensive technical plan exists, which } \\
\text { ensures the economic, social and ecological } \\
\text { sustainability of the teak plantation }\end{array}$ & Reformulated & KFRI \\
\hline & & 4.2 .1 & & A management plan is available & Unchanged & CIFOR \\
\hline & & 4.2 .2 & & Yield management plans ensure economic viability & Unchanged & KFRI \\
\hline & & & 4.2 .2 .1 & Yield regulation by area and/or volume prescribed & Unchanged & CIFOR \\
\hline & & & 4.2.2.2 & $\begin{array}{l}\text { The number of trees and/or volume of timber per hectare } \\
\text { harvested }\end{array}$ & Unchanged & KFRI \\
\hline & & & 4.2 .2 .3 & Plantation forestry activities to be linked with industries & New & $\begin{array}{l}\text { BIP/ } \\
\text { KFRI } \\
\end{array}$ \\
\hline & & 4.2 .3 & & Marketing strategies avoid gluts in the market & Unchanged & KFRI \\
\hline & & & 4.2.3.1 & $\begin{array}{l}\text { Marketing strategies to ensure maximum local-level value } \\
\text { addition }\end{array}$ & New & $\begin{array}{l}\text { BIP/ } \\
\text { KFRI }\end{array}$ \\
\hline & & 4.2 .4 & & $\begin{array}{l}\text { Management plans to ameliorate or counter natural } \\
\text { catastrophes (e.g., fires) and planning responses for } \\
\text { resources stabilisation and recovery }\end{array}$ & Reformulated & KFRI \\
\hline & & 4.2 .5 & & $\begin{array}{l}\text { Harvest regulation plans minimise adverse environmental } \\
\text { impacts }\end{array}$ & Reformulated & KFRI \\
\hline & & & 4.2.5.1 & The availability of clear, official harvesting rules & Reformulated & KFRI \\
\hline & & & 4.2 .5 .2 & Harvesting adheres to working plan prescriptions & & \\
\hline & 4.3 & & & The management plan is effectively implemented & Reformulated & ATO \\
\hline & & 4.3 .1 & & $\begin{array}{l}\text { Harvest efficiency and product utilisation ensures economic } \\
\text { sustainability }\end{array}$ & Reformulated & Scs \\
\hline & & & 4.3.1.1 & Production statistics of timber over time are available & Reformulated & KFRI \\
\hline & & & 4.3.1.2 & $\begin{array}{l}\text { The efficiency and economic viability of marketing of forest } \\
\text { products locally, regionally and internationally }\end{array}$ & Unchanged & KFRI \\
\hline & & & 4.3.1.3 & $\begin{array}{l}\text { Review of company's annual financial statements which } \\
\text { provide information such as annual return on investment } \\
\text { rates }\end{array}$ & Unchanged & KFRI \\
\hline & & & 4.3.1.4 & Actual yield per hectare as compared to predicted yield & Unchanged & KFRI \\
\hline & & 4.3 .2 & & Reduced-impact felling specified/implemented & Reformulated & ATO \\
\hline & & & 4.3.2.1 & Low-impact felling techniques are available & Reformulated & ATO \\
\hline & & & 4.3.2.2 & $\begin{array}{l}\text { Frequency of excessive felling damage to harvested trees } \\
\text { and extent of 'skinned' residual trees with tops broken } \\
\text { during harvesting operations }\end{array}$ & Reformulated & scs \\
\hline & & & 4.3 .2 .3 & $\begin{array}{l}\text { Directional felling techniques are being used (i.e., trees } \\
\text { are felled parallel to or in the direction of skidding) }\end{array}$ & Reformulated & SA \\
\hline
\end{tabular}


Annex 3.3 Continued

\begin{tabular}{|c|c|c|c|c|c|c|}
\hline $\mathrm{P}$ & C & I & V & Description & Observation & $\begin{array}{l}\text { Refer- } \\
\text { ence }\end{array}$ \\
\hline & & 4.3 .3 & & $\begin{array}{l}\text { Sustainable timber production (in quality and quantity) is } \\
\text { guaranteed }\end{array}$ & Unchanged & KFRI \\
\hline & & & 4.3.3.1 & $\begin{array}{l}\text { Silvicultural prescriptions (pre, during and post-harvest) } \\
\text { are being adhered to sustain the yield over rotations }\end{array}$ & Reformulated & KFRI \\
\hline & & & 4.3.3.2 & $\begin{array}{l}\text { Growth rates, stocking and regeneration are being } \\
\text { monitored by a suitable continuous forest inventory system }\end{array}$ & Reformulated & FSC \\
\hline & & & 4.3.3.3 & $\begin{array}{l}\text { Extent to which expedient prescriptions, such as diameter- } \\
\text { limit harvesting are routinely applied }\end{array}$ & Unchanged & KFRI \\
\hline & & & 4.3.3.4 & Less damage to stumps in the case of coppice systems & New & $\begin{array}{l}\text { BIP/ } \\
\text { KFRI } \\
\end{array}$ \\
\hline & & & 4.3.3.5 & Pre-logging stand inventory & Unchanged & ITTO \\
\hline & & 4.3 .4 & & Skidding damage to trees and soil is minimised & Unchanged & CIFOR \\
\hline & & & 4.3.4.1 & $\begin{array}{l}\text { Front end of logs is lifted off ground during mechanical } \\
\text { skidding }\end{array}$ & Unchanged & SWP \\
\hline & & & 4.3.4.2 & Skid trail gradients do not exceed 25 degrees & Unchanged & SWP \\
\hline & & & 4.3.4.4 & $\begin{array}{l}\text { Specifications in terms of skid trail width and location have } \\
\text { been set and are being followed }\end{array}$ & Unchanged & SWP \\
\hline & & 4.3 .5 & & $\begin{array}{l}\text { Forest management minimises impacts of logging on } \\
\text { plantation's structure and biodiversity }\end{array}$ & Unchanged & KFRI \\
\hline & & & 4.3.5.1 & Canopy opening is minimised & Unchanged & CIFOR \\
\hline & 4.4 & & & $\begin{array}{l}\text { An efficient monitoring and control system is } \\
\text { present to periodically revise management } \\
\text { prescriptions based on new information }\end{array}$ & Reformulated & FSC \\
\hline & & 4.4 .1 & & $\begin{array}{l}\text { Documentation and records of all management activities are } \\
\text { kept in a form that makes it possible for monitoring to occur }\end{array}$ & Unchanged & CIFOR \\
\hline & & 4.4 .2 & & $\begin{array}{l}\text { Monitoring procedures for acquiring information plan } \\
\text { attainment and resource conditions }\end{array}$ & Unchanged & KFRI \\
\hline & & & 4.4.2.1 & Records of annual areas cut over time & Reformulated & SWP \\
\hline & & & 4.4.2.2 & $\begin{array}{l}\text { Actual annual harvest levels as compared to planned } \\
\text { levels }\end{array}$ & Unchanged & KFRI \\
\hline & & & 4.4.2.3 & $\begin{array}{l}\text { Provision for monitoring the residual growing stock after } \\
\text { logging }\end{array}$ & Unchanged & KFRI \\
\hline
\end{tabular}


Annex 4 Example of a field diary, Dr Manish Misra - Bhopal Team

\begin{tabular}{|c|c|c|}
\hline Dates & Activities & Remarks \\
\hline 12-15 April 1999 & Form1 filled out at Bhopal & $\begin{array}{l}\text { Candidate sets for field testing } \\
\text { selected }\end{array}$ \\
\hline 20 June & $\begin{array}{l}\text { Discussion with team } \\
\text { members (KFRI-IIFM); } \\
\text { journey to Raipur }\end{array}$ & \\
\hline 21 June & $\begin{array}{l}\text { Arrival Raipur. Sensitisation } \\
\text { of local staff. Halt at Rawan }\end{array}$ & \\
\hline 22 June & $\begin{array}{l}\text { Visit to plantations. } \\
\text { Quadrat enumeration. } \\
\text { Interview with local staff }\end{array}$ & $\begin{array}{l}\text { Verification of biodiversity C\&I in relation to } \\
\text { NIFP }\end{array}$ \\
\hline 23 June & Visit to irrigated plantations & C\&I corrected for soil status, growth, etc. \\
\hline 24 June & $\begin{array}{l}\text { Visit to villages for linking } \\
\text { C\&I and their relevance } \\
\text { to ecology C\&I }\end{array}$ & Remarks of S. Sankar on restricting the C\&I social \\
\hline 25 June & $\begin{array}{l}\text { Visit to villages PRA on } \\
\text { biodiversity conservation, } \\
\text { income generation, etc. }\end{array}$ & Active participation of team \\
\hline 26 June & $\begin{array}{l}\text { Workshop at the guesthouses } \\
\text { filling out Form } 2\end{array}$ & \\
\hline 27 June & $\begin{array}{l}\text { Review of C\&I. Presentation } \\
\text { of results }\end{array}$ & \\
\hline 28 June & Return to Bhopal & \\
\hline 29 June & Review at Bhopal & \\
\hline
\end{tabular}

